\author{
UNIVERSIDADE DE SÃO PAULO \\ FACULDADE DE FILOSOFIA, LETRAS E CIÊNCIAS HUMANAS \\ DEPARTAMENTO DE LETRAS MODERNAS \\ ÁREA DE LÍNGUA ESPANHOLA E \\ LITERATURAS ESPANHOLA E HISPANO-AMERICANA
}

Andrea Nora Pizzutiello

Documentários-propaganda das ditaduras militares do Brasil (1964-1985) e da Argentina (1976-1983)

Uma comparação enunciativo discursiva

Versão Corrigida

SÃO PAULO

2017 


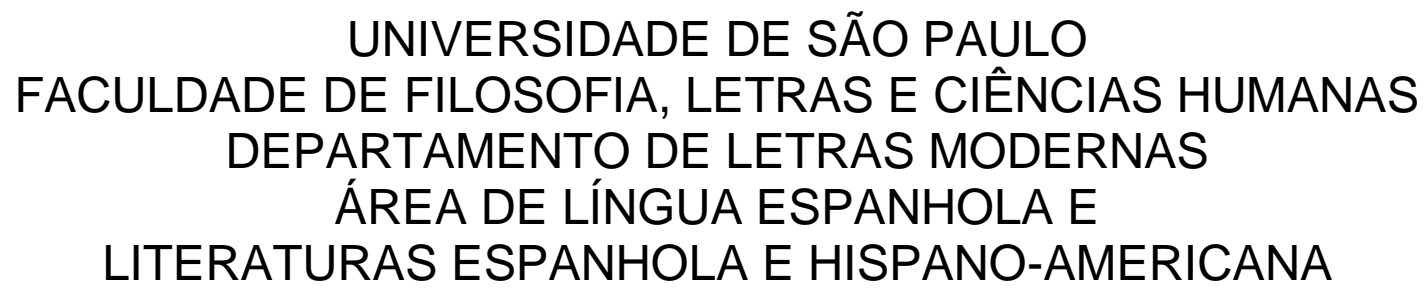

\title{
Documentários-propaganda das ditaduras militares do Brasil (1964-1985) e da Argentina (1976-1983) Uma comparação enunciativo discursiva
}

\author{
Versão Corrigida
}

Andrea Nora Pizzutiello

Dissertação de Mestrado apresentada no Programa de Pós-graduação em Língua Espanhola e Literaturas Espanhola e Hispano-Americana do Departamento de Línguas Modernas da Faculdade de Filosofia, Letras e Ciências Humanas da Universidade de São Paulo.

Orientador: Prof. Dr. Adrián Pablo Fanjul De acordo

São Paulo 2017 
Autorizo a reprodução e divulgação total ou parcial deste trabalho, por qualquer meio convencional ou eletrônico, para fins de estudo e pesquisa, desde que citada a fonte.

Catalogação na Publicação

Serviço de Biblioteca e Documentação

Faculdade de Filosofia, Letras e Ciências Humanas da Universidade de São Paulo

Pizzutiello, Andrea Nora

P695d Documentários-propaganda das ditaduras militares do Brasil (1964-1985) e da Argentina (1976-1983)

Uma comparação enunciativo discursiva / Andrea Nora Pizzutiello; orientador Adrián Pablo Fanjul. - São Paulo, 2016.

$132 \mathrm{f}$.

Dissertação (Mestrado) - Faculdade de Filosofia, Letras e Ciências Humanas da Universidade de São Paulo. Departamento de Letras Modernas. Área de concentração: Língua Espanhola e Literaturas Espanhola e Hispano-Americana.

1. documentário-propaganda. 2. Ditaduras Brasil e Argentina. 3. Gêneros discursivos. 4. Modalidade expositiva. 5. Discurso-constituinte. I. Fanjul, Adrián Pablo, orient. II. Título. 


\section{Banca Examinadora}

Prof. Dr. Adrián Pablo Fanjul (orientador)

Profa. Dra. Fernanda dos Santos Castelano Rodrigues UFSCAR

Profa. Dra. Graciela Alicia Foglia UNIFESP

\section{Suplentes}

Prof. Dr. Ivan Rodrigues Martins (UNIFESP)

Profa. Dra. María Zulma Moriondo Kulikowski (DLM/USP)

Profa. Dra. María Teresa Celada (DLM/USP) 
Para mi hijo Pedro 


\section{Agradecimentos}

Ao meu orientador Prof. Dr. Adrián Pablo Fanjul pela sua generosidade, confiança e incentivo, que possibilitaram a realização deste trabalho. E especialmente pela amizade.

A presença na Banca de Qualificação da Profa Dra Fernanda Dos Santos Castelano Rodrigues e da Profa. Dra. Graciela Alicia Foglia, pelos valiosos aportes que fizeram a este trabalho.

À minha querida amiga Claudia Cecília Jacobi, pelos 35 anos de amizade e cumplicidade, por ter me encorajado e apoiado desde sempre em todas as minhas iniciativas acadêmicas.

Ao meu amigo Martín Russo, pela amizade e por ter me mostrado que é possível realizar alguns sonhos.

Aos meus amigos do Brasil, da Argentina e do mundo, minha família escolhida, pelas conversas enriquecedoras, pelos momentos compartilhados, pelo apoio, pela presença na vida e pelo carinho.

Às queridas e sempre presentes Analu Sério, Luana Chnaiderman de Almeida, Roseana Pellozo, Neide Elias e Renata Gomes, pelo incentivo e pela alegria nos nossos encontros.

A los argentinos de siempre, Claudia Otero, Enrique Melone, Laura Yankillevich e Martha Calderón, por su amistad de tantos años.

Aos meus amigos professores e aos meus alunos, com quem sempre aprendo. A mis viejos, Guga y Alfredo Pizzutiello, por todo el amor, las historias y los colores que compartimos. 
"Si me es dado elegir, me pondré del lado del 'exceso' de historia, tanto más poderoso es mi terror al olvido que el temor de tener que recordar demasiado" Yosef Hayim Yerushalmi 


\section{Sumário}

$\begin{array}{ll}\text { Resumo } & 09\end{array}$

Resumen 10

$\begin{array}{ll}\text { Abstract } & 11\end{array}$

INTRODUÇÃO 12

CAPÍTULO 1 - Apresentação do corpus e condições de produção 16

1. Apresentação 16

2. O corpus 16

2.1 Brasil de Ontem, Hoje e Amanhã 18

$\begin{array}{ll}2.2 \text { Ganamos la paz } & 19\end{array}$

3. As condições de produção 20

3.1 Brasil de Ontem, Hoje e Amanhã - Realização: Agência Nacional 22

3.1.1 Espaço de veiculação: Programa Amaral Netto, o Repórter 23

3.1.2 Sintonizando nas Organizações Globo 27

3.1.3 Cid Moreira, a voz do Jornal Nacional e (Des)memória Globo 28

3.2 Si te he visto no me acuerdo 31

3.2.1 Suposições e questionamentos sobre a produção de Ganamos la Paz 33

3.2.2 Memória oculta 35

3.2.3 Construindo com a memória $\quad 35$

3.3 Os regimes militares 38

3.3.1 Regime militar na Argentina (1976-1983) 39

3.3.2 O regime militar no Brasil (1964-1985) 43

3.4 A doutrina francesa de "Guerra Revolucionária" nos regimes militares $\quad 49$

3.4.1 Processo de importação do terror 50

3.4.2 Ação psicológica no Brasil e na Argentina 52

CAPÍTULO 2 - Alguns conceitos teóricos $\quad 57$

1. O gênero documentário

$\begin{array}{ll}1.1 \text { Modalidades do documentário } & 60\end{array}$

1.1.1 A modalidade expositiva 60

2. O Discurso Constituinte 63

3. Cenografia e cena enunciativa 66

$\begin{array}{ll}3.1 \text { O enunciador } & 677\end{array}$

$\begin{array}{ll}3.2 \text { Heterogeneidade no discurso } & 68\end{array}$ 
CAPÍTULO 3 - Análise dos filmes $\quad 70$

1. Ganamos la Paz 70

1.1 Dime cómo te llamas y no sabré quién eres $\quad 70$

1.1.1 Nós quem?

$\begin{array}{ll}\text { 1.1.2 La guerra sucia } & 74\end{array}$

1. 2 O inimigo subversivo $\quad 75$

1.2.1 Um país contaminado $\quad 77$

1.3 A interlocução representada $\quad 81$

1.3.1 A cena enunciativa e o locutor 82

1.3.1.1 Os salvadores da pátria 83

2. Brasil de ontem hoje e amanhã 85

2.1 O título $\quad 85$

2.2 A ilha Brasil e o Brasil Grande $\quad 87$

2.2.1 O gigante de joelhos $\quad 89$

$\begin{array}{ll}2.3 \mathrm{O} \text { inimigo } & 91\end{array}$

2.3.1 Os salvadores da pátria 93

2.4 A cena enunciativa e os locutores 95

2.5 A interlocução representada 96

2.5.1 Você se lembra? 966

2.5.2 Nós quem? 99

2.5.3 O povo e o(s) brasileiro(s) 102

$\begin{array}{ll}\text { CONSIDERAÇÕES FINAIS } & 1066\end{array}$

$\begin{array}{ll}\text { Referências bibliográficas e de internet } & 108\end{array}$

ANEXOS 112

$\begin{array}{lr}\text { Transcrição dos filmes } & 112\end{array}$

BRASIL DE ONTEM HOJE E AMANHÃ

GANAMOS LA PAZ 124 


\section{Resumo}

Neste trabalho comparamos dois documentários-propaganda das ditaduras do Brasil (1964-1985) e da Argentina (1976-1983). Nossa pesquisa busca desenvolver uma análise enunciativo discursiva dos dois documentários que permita estabelecer relações com aspectos das suas condições de produção e com as características do enunciador e do co-enunciador. Trata-se dos filmes, Brasil de Ontem, Hoje e Amanhã, exibido em 1975 no programa Amaral Netto, o Repórter da Rede Globo e Ganamos la Paz, exibido em 1977 no canal 7 da televisão argentina. Os dois filmes expõem a versão dos governos militares da situação política e social daqueles anos, justificando a necessidade de intervenção das forças armadas, que se apresentam como a única instituição capaz de conter o avance de um mesmo inimigo: o comunismo. A noção de condições de produção mostrou-se especialmente produtiva porque nos permitiu indagar o âmbito institucional dos dois países e a circulação de superfícies discursivas produzidas a partir de uma mesma doutrina na qual ambos os regimes se fundamentaram: a de Guerra Revolucionária francesa. $O$ estudo do funcionamento e da modalidade de representação expositiva do gênero documentário (Nichols, 1997), as categorias de discurso constituinte (Maingueneau, 2008) e de heterogeneidade discursiva (Authier Revouz, [1982] 2011) foram fundamentais em nossa análise. Dessa forma, pudemos estabelecer não apenas relações interdiscursivas, mas também entre os diferentes lugares de dizer que o enunciador ocupa, a representação do inimigo e a interlocução representada nos dois filmes.

Palavras chave: documentário-propaganda, ditaduras Brasil e Argentina, gêneros discursivos, modalidade expositiva, discurso-constituinte. 


\section{Resumen}

En este trabajo comparamos dos documentales-propaganda de las dictaduras de Brasil (1964-1985) y de Argentina (1976-1983). En esta investigación buscamos desarrollar un análisis enunciativo discursivo de los documentales que permita establecer relaciones con aspectos de sus condiciones de producción y con las características del enunciador y del coenunciador. Las películas son Brasil de Ontem, Hoje e Amanhã, exhibida en 1975 en el programa Amaral Netto, o Repórter de la Rede Globo y Ganamos la Paz, exhibida en 1977 en el canal 7 de la televisión argentina. Los dos documentales exponen la versión de los gobiernos militares de la situación política y social de esa época, justificando la necesidad de intervención de las fuerzas armadas, que se presentan como la única institución capaz de contener el avance de un mismo enemigo: el comunismo. La noción de condiciones de producción se mostró especialmente productiva porque nos permitió indagar el ámbito institucional de los dos países y la circulación de superficies discursivas producidas a partir de una misma doctrina, en la cual ambos regímenes se fundamentaron: la de Guerra Revolucionaria francesa. El estudio del funcionamiento y de la modalidad de representación expositiva del género documental (Nichols, 1997), las categorías de discurso constituyente (Maingueneau, 2008) y de heterogeneidad discursiva (Authier Revouz, [1982] 2011) fueron fundamentales en nuestro análisis. De este modo, pudimos establecer no sólo relaciones interdiscursivas, sino también entre los diferentes lugares de decir que el enunciador ocupa, la representación del enemigo y la interlocución representada en los documentales.

Palavras clave: documentales-propaganda, dictaduras Brasil y Argentina, géneros discursivos, modalidad expositiva, discurso constituyente. 


\begin{abstract}
In this study we compare two propagandistic documentary films of the Brazilian (1964-1985) and Argentinean (1976-1983) dictatorships. Our research aims at carrying out a discourse and enunciation analysis in order to relate some aspects of their production conditions with the enunciator's and co-enunciator's characteristics. The films under study were Brasil de Ontem, Hoje e Amanhã, exhibited in 1975 on Rede Globo's Amaral Netto, o Repórter show, and Ganamos la Paz, exhibited in 1977 on channel 7 in Argentina. Both films exposed the military government version of the political and social situation in those years, justifying the intervention of the armed forces which introduce themselves as being the sole institution capable of hindering the progress of the same enemy: communism. The production condition notion has proved to be productive since it allowed us to get into the institutional framework of both countries and into the circulation of discursive surfaces produced based on the same doctrine to which both governments adhere, namely the French Revolutionary War. The study of the functioning and representation mode of the documentary genre (Nichols, 1997), the constitutive discourse categories (Maingueneau, 2008), and the discursive heterogeneity (Authier Revouz, [1982] 2011) were of the utmost importance in our analysis. Therefore we were able to assess not only interdiscursive relations, but also the place of speech the enunciator occupies, the representation of the enemy and the interlocution represented in both films.
\end{abstract}

Keywords: propagandistic documentary films, Brazil and Argentina dictatorships, discursive genre, expositive mode, constitutive discourse. 


\section{INTRODUÇÃO}

\section{Um pouco de minha história}

As ditaduras se estabeleceram em vários países da América Latina no século XX. No Brasil, o último regime militar tomou o poder em 1964 e permaneceu até 1985. Na Argentina, que desde 1930 vinha alternando regimes militares com alguns poucos anos de governos democráticos, o último governo militar permaneceu no poder desde 1976 até 1983. Há muitos pontos em comum e muitos divergentes entre ambos os regimes, no entanto consideramos que os processos históricos e a produção discursiva institucional são passíveis de comparação.

Comparar faz parte da vida de muitos que, assim como eu, saíram do seu país de origem. Nasci e vivi em Buenos Aires até 1978, quando vim com a minha família para São Paulo para nos preservar da violência e do terrorismo de estado imposto pelo regime militar argentino.

Vivemos um período muito difícil, amigos e conhecidos eram sequestrados, assassinados ou presos por sua oposição ao regime. Meus pais perceberam o perigo que corríamos quando, em outubro de 1976, vários estudantes do colégio no qual estudávamos meu irmão e eu foram sequestrados. Eram jovens secundaristas que tinham na época entre 17 e 21 anos, que atuavam no movimento estudantil. Eles fazem parte da lista das 30000 pessoas vítimas do terrorismo de estado e permanecem desaparecidos até hoje.

Vindos de uma experiência traumática que nos marcou profundamente encontramos dificuldades em nos adaptar à nossa nova vida no Brasil. Outro país, outra cidade, outro idioma e outra cultura, muitas informações para compreender, interpretar e assimilar simultaneamente. Tudo isso esteve naturalmente marcado pela constante comparação com aquilo que já conhecíamos. Estávamos saindo de um país que vivia sob um regime militar e chegando a outro que estava na mesma situação. No entanto, eram muito diferentes. O regime que conhecíamos era sinônimo de violência de insegurança e incerteza. $O$ regime brasileiro se apresentava como um regime já estabelecido há tempos: as pessoas circulavam com tranquilidade pelas ruas, não se viam caminhões do exército nem carros com capangas 
ameaçadores ostentando suas armas, não havia carros de polícia na porta da escola, nem soldados, nem terror, não no bairro de classe média onde nos instalamos em São Paulo. O país respirava "normalidade".

Apesar de estar em plena adolescência e das minhas percepções serem as de uma jovem de 15 anos, o regime militar brasileiro me causava estranheza. Percebia a forte desigualdade social, a contradição entre a "alegria brasileira" e a extrema pobreza. Não entendia como a relação ditadurasociedade havia se estabelecido, o que havia acontecido no passado e de que forma essa história estava presente naquele momento.

No final da década de 1970 ficava claro que a ditadura brasileira estava chegando ao fim. O governo Geisel (1974-1979) iniciara o processo de abertura política de forma, "lenta, gradual e segura", que se concretizou no governo do general João Baptista de Oliveira Figueiredo (1979-1985) ao sancionar a lei 6683, popularmente conhecida como Lei de Anistia.

As contradições foram se tornando cada vez mais evidentes. Lembro de ter ficado muito impressionada com a declaração do então presidente João Figueiredo ao ser questionado sobre a abertura política: "É para abrir mesmo. E quem quiser que não abra, eu prendo. Arrebento. Não tenha dúvidas”.

A pesar da abertura e da possibilidade de retorno de um governo democrático, sentíamos medo. Principalmente quando começaram a circular textos produzidos na França, nos quais sobreviventes dos centros clandestinos de detenção argentinos narravam os horrores pelos quais haviam passado. Começava a ficar evidente que havia um plano sistemático de sequestro, tortura e desaparecimento de pessoas. Soube que no Brasil também haviam acontecido sequestros e desaparecimentos. Estaríamos realmente seguros em São Paulo?

Naquela época, apesar de que meu pai trabalhava oficialmente, nos foi negado o visto permanente para morar no Brasil. Legalmente éramos turistas, portanto, precisávamos sair do país para renovar o visto a cada 6 meses. Fazíamos viagens à tríplice fronteira, saíamos do país pelo Paraguai, íamos até a cidade de "Puerto Stroessner" (atual Ciudad del Este) para imediatamente retornar ao Brasil. Eram viagens muito tensas.

O medo se intensificou ainda mais com a visita do General Videla ao Brasil, em 1980, e com a circulação de notícias de que havia um plano de 
colaboração, coordenação e apoio entre as cúpulas militares do Chile, da Argentina, do Brasil e do Uruguai, com apoio dos Estados Unidos. Essa coordenação de ações, posteriormente conhecida como Operação Condor, consistiu na vigilância, detenção e translado entre os países, desaparecimento e morte de pessoas. É preciso relembrar que o caráter clandestino dessa organização internacional a tornara ainda mais assustadora.

No final de 1982 obtivemos um documento de caráter provisório que nos permitiu permanecer no Brasil. Foi somente em 1983 que finalmente ganhamos o status de estrangeiros residentes permanentes no país e que os medos se dissiparam quase por completo.

Nesses primeiros anos de exílio a comparação entre os dois países era inevitável. Entendi que no Brasil a história tinha sido diferente e aos poucos percebi as marcas que o regime militar brasileiro deixara.

Talvez tenham sido essas vivências as que tenham despertado o interesse em investigar esses processos históricos e desenvolver este trabalho comparativo.

\section{A organização desta dissertação}

No Capítulo 1 apresentamos o corpus e uma das noções centrais desta pesquisa: as condições de produção. Dessa forma, descrevemos as características dos documentários, algumas informações sobre as instituições envolvidas na sua veiculação, bem como as lacunas de informação com as quais nos deparamos. Fazemos um breve histórico dos regimes militares, da doutrina francesa de Guerra Revolucionária que sustentava as ações institucionais nos dois países e observamos como alguns textos produzidos no marco dessa doutrina nos ajudam a estabelecer relações interdiscursivas.

No Capítulo 2 apresentamos alguns dos conceitos teóricos que mobilizamos em nossa análise: o gênero documentário e suas modalidades, os discursos de sobriedade, o discurso constituinte, a cena enunciativa, 0 enunciador e a heterogeneidade discursiva.

No Capítulo 3, apresentamos a análise dos filmes juntamente com alguns conceitos teóricos que consideramos conveniente entrelaçar ali. 
Nas Considerações finais retomamos alguns aspectos centrais desenvolvidos neste trabalho.

Nos Anexos, o leitor encontrará a transcrição das falas dos filmes Brasil de Ontem Hoje e Amanhã e Ganamos la Paz, bem como os links onde se encontram hospedados para poder assisti-los. 


\section{CAPÍTULO 1 - Apresentação do corpus e condições de produção}

\section{Apresentação}

Este trabalho propõe uma comparação entre discursividades produzidas durante os últimos regimes civis militares do Brasil (1964-1985) e da Argentina (1976-1983), mais especificamente, nosso interesse é comparar discursos institucionais produzidos durante esses governos indagando características das suas condições de produção e do enunciador e co-enunciador.

Enquanto estavam no poder, os governos militares produziram uma série de discursos que circulavam por diversos espaços e que tinham diferentes finalidades. Comunicados, leis, decretos e propagandas eram difundidos nos meios de comunicação de massa. Nosso interesse é analisar discursos que foram divulgados na mídia, pensando nela como um espaço de práticas discursivas, que se realizam dentro de um processo histórico, nos quais diferentes sujeitos assumem diferentes posições na circulação de enunciados. Com essa perspectiva nosso recorte dentro dessa prática discursiva foi a propaganda oficial cujo suporte fossem audiovisuais difundidos através da televisão ou do cinema.

Dessa forma, procuramos um corpus homogeneizado por enquadrar-se em um mesmo gênero de discurso, que definiremos no Capítulo 2, por se tratar de uma identidade em comum entre discursos produzidos em países e em momentos e línguas diferentes.

\section{2. $O$ corpus}

Iniciamos a busca por propagandas e procuramos audiovisuais que tivessem sido publicados e estivessem classificados na internet como propagandas oficiais da ditadura. Pensando no termo "oficial", como vimos no 
Dicionário Houaiss, como aquilo que é: "emanado do governo ou de uma autoridade administrativa reconhecida", ou ainda "certificado pela autoridade pública ou por uma autoridade competente" e "apresentado como verdade pela autoridade pública ou por uma autoridade reconhecida".

Em um primeiro momento pensamos que a propaganda oficial poderia nos oferecer superfícies discursivas nas quais poderíamos observar como os regimes militares dos dois países se identificavam, como se apresentavam, contavam sua própria história, como se estabeleciam na cena enunciativa e como se dava a relação com seu espectador.

Ao selecionar as palavras chave propaganda-ditadura-militar-Brasil nos mecanismos de busca da Internet, encontramos o filme Brasil de Ontem, Hoje e Amanhã. Trata-se de um documentário-propaganda que não é exatamente oficial, pois não há uma autoridade pública que assuma sua autoria, mas tratase sim de uma propaganda dos regimes militares durante os anos de 1964 até 1975 apresentada a partir de um lugar de autoridade competente que fala em nome do regime. Por se tratar de um documentário é uma superfície discursiva de maior extensão, que foi veiculada de forma mais pontual do que uma propaganda de curta duração.

Tendo encontrado o gênero documentário-propaganda passamos a procurar material análogo produzido na Argentina, sem saber se encontraríamos algo que pudesse ser comparado com o filme brasileiro. Nossa busca nos levou ao filme Ganamos la Paz, um documentário-propaganda, no qual também não há a voz de uma autoridade oficial presente, mas há também a presença de uma voz que fala em nome do regime, que demonstra e justifica a suposta necessidade de intervenção das forças armadas.

Faremos a seguir uma breve descrição dos dois filmes que encontramos para formar nosso corpus, deste modo poderemos observar a forte comparabilidade que há entre ambos, apesar de terem sido produzidos em estados nações diferentes, em línguas e em momentos diferentes. 


\subsection{Brasil de Ontem, Hoje e Amanhã}

Chamou nossa atenção a descrição que acompanhava um documentário: "Exaltação e propaganda da ditadura militar na Rede Globo". Aprofundamos nossa busca e encontramos o filme brasileiro em um marco institucional confiável. Trata-se de Brasil de Ontem, Hoje e Amanhã, publicado no site Zappiens.br. O site é um projeto experimental que disponibiliza um serviço gratuito de agregação e distribuição de conteúdo audiovisual científico, educativo, artístico e cultural em língua portuguesa e que foi criado em parceria com o Arquivo Nacional, entre outras instituições. A descrição que acompanha o filme é a seguinte:

Título: Brasil de Ontem, Hoje e Amanhã (1975)

Tipo: Documentário

Resumo: Programa "Amaral Netto Especial", sobre os acontecimentos políticos, econômicos e sociais no Brasil, entre 1963 e 1975; o desenvolvimento econômico e as realizações de cada presidente após 1964; apresentação de concerto na Quinta da Boa Vista, no Rio de Janeiro.

O documentário Brasil de Ontem, Hoje e Amanhã mostra uma retrospectiva que começa no governo João Goulart, em 1961, passa pelo momento do golpe, em 1964 e pelas realizações de quatro dos governos do regime militar. O locutor em off narra e mostra imagens de greves, de multidões e da possibilidade de violência nas ruas, esses seriam, de acordo com ele, os sinais do "caos" que havia durante o governo João Goulart e da "ameaça vermelha" que estaria presente na América Latina desde 1959 com a revolução cubana. O filme nos mostra o que teria sido um passado caótico que justifica a necessidade de intervenção das forças armadas que se apresentam como "salvadores da pátria". A partir desse acontecimento o documentário é dedicado a mostrar os supostos benefícios trazidos pelo governo militar, os ganhos obtidos na produção e crescimento econômico do país, dando ênfase aos êxitos que o Milagre Econômico teria trazido à população brasileira. São mostradas as obras realizadas pelos governos dos presidentes Castello Branco, Costa e Silva, Médici e Geisel, e o desenvolvimento ocorrido após o golpe de 1964, bem como projeções para o futuro do país. 


\subsection{Ganamos la paz}

Explorando o site "Canal Encuentro", vinculado ao canal de televisão do Ministério de Educação da República Argentina, encontramos vários programas sobre a última ditadura. O que se destacou pela descrição que o acompanha, foi o filme Ganamos la paz:

El historiador y crítico de cine Fernando Martín Peña presenta Ganamos la Paz, un documental que, a modo de propaganda oficial de la Junta Militar, celebra el accionar político, económico y social llevado adelante durante el Proceso de Reorganización Nacional.

Realizado em 1977, ou seja, pouco mais de um ano depois do golpe de 24 de março de 1976, o filme é uma versão de um período da história argentina narrada a partir do ponto de vista dos militares. De acordo com o historiador argentino Fernando Martín Peña, que apresenta o filme, o documentário tem um grande valor, porque se trata de um documento de testemunho da retórica da junta militar, de como a ditadura de 1976 pensava a si mesma.

O audiovisual apresenta a Argentina como um país de natureza privilegiada, uma terra rica que atraiu "olhares cobiçosos daqueles que querem conquistar, aproveitar, explorar a terra e escravizar seus homens". São mostrados os tesouros nacionais, grandes nomes da história argentina, ganhadores do prêmio Nobel e destacados esportistas. Ainda de acordo com o filme, o país vivia em paz até que o "câncer da violência ideológica" contamina a América Latina. No filme argentino também se faz uma retrospectiva da história, mas diferentemente do filme brasileiro são mostradas imagens do Chile, de Cuba e de outros países e seus governos socialistas, sugerindo que o país está sob uma ameaça externa, um "câncer que o contamina" e faz com que a sociedade adoeça. Surge assim a figura dos salvadores da pátria: "Las fuerzas armadas se ven en la obligación de asumir el poder y lo hacen el 24 de marzo de 1976 para preservar la integridad de la nación”. Depois de as forças armadas terem assumido o controle do país, o filme descreve como muitos "delinquentes subversivos" são presos. Finalmente é mostrada a tranquilidade e a paz obtidas graças à intervenção das forças armadas, com as imagens de 
um pai de família que anda nas ruas do centro de Buenos Aires indo ao encontro da sua esposa e filha.

Definimos então que, ao comparar e analisar esses dois documentários, verificaríamos que relação poderíamos encontrar entre aspectos da configuração enunciativa e as condições de produção das quais eles surgem. Focalizaremos as condições de produção dos filmes selecionados, considerando os sujeitos e a situação nas quais esses filmes foram produzidos, compreendidos e interpretados. Também buscamos analisar como se enquadram os dois documentários, a partir dessa perspectiva de análise, nas diferentes formas que assumiram em cada país os regimes militares e as diferenças que adquiria a desigualdade social. Nessas formas estão incluídas as estruturas institucionais montadas pelos regimes, os modos de relação com os diferentes setores sociais e os modos de funcionamento da propaganda de ambos.

A seguir, faremos uma apresentação detalhada daquilo que consideramos "condições de produção" dos documentários objeto de nosso estudo. Começaremos definindo o alcance com que empregamos essa categoria, a partir disso se compreenderá o motivo pelo qual descrevemos fatores de natureza diversa. Trataremos sobre a situação imediata de produção dos filmes, sobre o ordenamento institucional dos regimes de exceção e sobre séries discursivas que vemos relacionadas com os documentários que estamos analisando. O modo como a Análise do Discurso concebe as condições de produção nos permite articular esses fatores de características diferentes.

\section{As condições de produção}

Uma das categorias teóricas que mobilizamos em nossa pesquisa são as "condições de produção" (CP). Aplicaremos o conceito de CP de acordo com as definições propostas por Pêcheux ([1969]1990) e por Courtine (1981). Para Pêcheux, "um discurso é sempre pronunciado a partir de 
condições de produção dadas". ([1969]1990.77). Ao definir as condições de produção, o autor afirma:

[‥] os fenômenos linguísticos de dimensão superior à frase podem efetivamente ser concebidos como um funcionamento mas com a condição de acrescentar imediatamente que este funcionamento não é integralmente linguístico, no sentido atual desse termo e que não podemos defini-lo senão em referência ao mecanismo de colocação dos protagonistas e do objeto de discurso, mecanismo que chamamos de "condiç̃ões de produção" do discurso" (Pêcheux, [1969]1990:78, grifos do autor)

Nesse sentido, o autor acredita que não é possível analisar um discurso como um texto considerando que ele é uma sequência linguística fechada em si mesma, é preciso "referi-lo ao conjunto de discursos possíveis a partir de um estado definido das condições de produção" (Pêcheux, [1969]1990:79). E ainda: "o que funciona nos processos discursivos é uma série de formações imaginárias que designam o lugar que $\mathrm{A}$ e $\mathrm{B}$ se atribuem cada um a si e ao outro, a imagem que eles fazem de seu próprio lugar e do lugar do outro" ([1969]1990:82)

De acordo com esta perspectiva, o sujeito é afetado pelo social, ele não decide seu discurso de forma individual. Embora tenha a impressão de ser o responsável pelo seu discurso, ele é um sujeito socialmente constituído, que ocupa um determinado lugar na estrutura de uma formação social.

Para o autor a memória discursiva ou interdiscurso é o que possibilita que o dizer tenha sentido, e que corresponde a algo já dito anteriormente em outro lugar, desta forma, haveria um processo de "assujeitamento do sujeito como sujeito ideológico", no qual cada um seria conduzido a reproduzir as relações de classe "tendo a impressão de estar exercendo sua livre vontade, a ocupar seu lugar em uma ou outra das duas classes sociais antagonistas no modo de produção" (Pêcheux e Fuchs ([1975] 1990:166). Os autores consideram que as superfícies linguísticas ou objetos discursivos são dominados por "condições de produção estáveis e homogêneas".

Posteriormente, Courtine (1981) vai propor uma reformulação da noção de CP dada por Pêcheux, e entenderá as "condições de produção" como as relações de oposição e delimitação entre sequências discursivas determinadas 
pelas condições institucionais e as relações de dominação e força na formação social.

Escolher uma sequência discursiva de referência equivale assim a determinar a pertinência histórica de tal conjuntura, a situar a produção dessa sequência na circulação de formulações trazidas por sequências discursivas que se opõem, se respondem, se citam [...], a descrever, enfim, o âmbito institucional e as circunstâncias enunciativas dessa produção. (Courtine ([1981]2009:108)

Courtine propõe assim que uma formação discursiva é determinada pelo seu exterior, considerando seu conteúdo empírico e heterogêneo. Ao mobilizarmos a noção de condições de produção, observaremos quais relações se estabelecem entre aspectos das condições sociais, históricas e ideológicas e os sujeitos da enunciação e quais marcas podemos encontrar na materialidade linguística dos enunciados. Empregar a noção de CP nos levará a pensar também em como o discurso pode ser compreendido e interpretado em determinada situação de enunciação e nos servirá para entender e analisar como nosso corpus se inscreve em uma relação de lugares que operam dentro de um aparelho ideológico.

Portanto, consideramos importante explorar o âmbito institucional que envolve a realização dos filmes. Sendo assim, descreveremos as instituições direta e indiretamente envolvidas na realização e veiculação dos filmes, bem como as características que assumiram os regimes militares e o modo como chegaram ao poder em cada país.

\subsection{Brasil de Ontem, Hoje e Amanhã - Realização: Agência Nacional}

O filme Brasil de Ontem, Hoje e Amanhã foi produzido pela Agência Nacional (AN). Criada em 1945, pelo então presidente Getúlio Vargas, após a extinção do Departamento de Imprensa e Propaganda (DIP), a AN estava subordinada ao Departamento Nacional de Informações. Era a AN que distribuía as notícias e divulgava os eventos ligados ao governo. 
De acordo com o site Memórias Reveladas:

[...] 0 órgão ficou diretamente subordinado ao Ministério da Justiça. Em 1971, a Agência passou a transmitir, diretamente ou em colaboração com os órgãos de divulgação, o noticiário referente aos atos da administração federal e as notícias de interesse público, além da publicidade dos órgãos governamentais

Um dos programas de rádio mais antigos e dos mais conhecidos do público brasileiro produzidos pela AN é $A$ Voz do Brasil, que existe desde 1935 e é de veiculação obrigatória em todas as rádios do país. O programa informa notícias sobre os Poderes Executivo, Legislativo e Judiciário. Atualmente, no entanto, algumas rádios, amparadas por liminares, estão desobrigadas de sua transmissão. O programa A Voz do Brasil ficou também conhecido pela vinheta que usava a abertura de $O$ Guarani, de Carlos Gomes.

Os filmes produzidos pela AN também mostravam eventos relacionados à Presidência da República e a pessoas e instituições diretamente ligadas ao governo; discursos, inaugurações, visitas de autoridades, festas pátrias e atualidades. No site Memórias Reveladas a AN é apresentada sob o título: "A ditadura por sua agência".

Durante o governo de João Figueiredo, em 1979, a AN foi sucedida pela Empresa Brasileira de Notícias. Em 1988 a EBN foi extinta e incorporada à Radiobrás, que por sua vez, em 2007, foi incorporada à Empresa Brasileira de Comunicações S.A.

O fundo da AN foi reunido no Arquivo Nacional no início dos anos 1980 e parte do acervo audiovisual está hospedado no site Zappiens.br.

\subsubsection{Espaço de veiculação: Programa Amaral Netto, o Repórter}

Brasil de Ontem, Hoje e Amanhã foi exibido em 1975, em um programa chamado Amaral Netto, o Repórter que era veiculado pela Rede Globo e apresentado pelo jornalista Amaral Netto.

\footnotetext{
${ }^{1}$ A ditadura por sua agência

http://www.memoriasreveladas. arquivonacional.gov. br/cgi/cgilua.exe/sys/start.htm?infoid=31\&sid=10
} 
O programa Amaral Netto, o Repórter estreou na TV Tupi em maio de 1968 e, em dezembro do mesmo ano, passou a ser apresentado pela Rede Globo. Segundo Krause (2016:41) o programa tinha uma hora de duração e foi exibido primeiro aos domingos. A partir de agosto de 1970 foi exibido aos sábados às $22 \mathrm{~h} 30$ e a partir de 1974 o programa migrou para as segundas feiras à noite, sendo que em 1976 chegou a obter seus maiores picos de audiência.

O jornalista Amaral Netto viajava pelo Brasil e mostrava paisagens, costumes e tradições brasileiras desconhecidas pelo grande público: as belezas das Cataratas de Foz do Iguaçu, a pesca da baleia, as atividades dos pelotões militares nas regiões de fronteira, isso em uma época na qual a maioria dos programas de televisão ainda era feita dentro dos estúdios. O programa usava um formato inovador que apresentava reportagens e pesquisas nas quais o discurso ufanista e desenvolvimentista estava presente.

O site da empresa O Globo $^{2}$ descreve assim o programa Amaral Netto, $O$ Repórter. "[...] com equipamento sofisticado para a época, alcançava as mais longínquas regiões do país e divulgava as obras do governo durante o regime militar".

A carreira do jornalista e apresentador do programa Fidélis dos Santos Amaral Netto aconteceu concomitantemente com a sua carreira política. Embora ele não esteja presente no filme Brasil de Ontem, Hoje e Amanhã, é no espaço que leva seu nome que o filme foi exibido, e de alguma maneira o jornalista empresta seu nome e sua identidade à cena enunciativa ${ }^{3}$. Consideramos necessário, portanto descrever sua trajetória, desta maneira poderemos também observar como os meios de comunicação estavam articulados com a vida política do país.

Fidelis dos Santos Amaral Netto nascido em Niterói, então capital do Estado do Rio de Janeiro, em 28 de abril de 1921 iniciou sua carreira como jornalista no jornal Correio da Noite, no final da década de 1940. Foi então que se aproximou de Carlos Lacerda, a quem ajudou a fundar a Tribuna da

\footnotetext{
${ }^{2}$ Memoria Globo

http://memoriaglobo.globo.com/programas/jornalismo/programas-jornalisticos/amaral-netto-o-reporter/evolucao.htm

${ }^{3}$ Apresentaremos o conceito de cena enunciativa no Capítulo 2
} 
Imprensa, jornal que se caracterizou por ser firme opositor do segundo governo de Getúlio Vargas. Carlos Lacerda e Amaral Netto fundaram juntos o Clube dos Lanternas uma agremiação suprapartidária formada por políticos conservadores, que se caracterizou por fazer duras críticas aos Governos de Getúlio Vargas e Juscelino Kubischek. Em 1960 elegeu-se deputado pela União Democrática Nacional, de orientação conservadora, e em 1962 foi eleito deputado federal. De acordo com o verbete biográfico da FGV, o jornalista Amaral Netto: ${ }^{4}$

\begin{abstract}
Intimamente identificado com o governador da Guanabara, Carlos Lacerda, um dos principais conspiradores do golpe contra o governo Goulart, teve uma participação ativa no movimento político-militar de 31 de março de 1964, que instaurou um regime de exceção no país.
\end{abstract}

Uma vez instaurado o regime militar e com o bipartidarismo, em 1965, Amaral Netto filiou-se ao Movimento Democrático Brasileiro (MDB), partido de oposição ao governo, foi reeleito ainda nessa legenda, mas no início de 1967 deixou o MDB e ingressou no partido governista, a Aliança Renovadora Nacional (Arena). Com o fim do bipartidarismo filou-se ao Partido Democrático Social. Ele cumpriu oito mandatos como deputado. Sua atuação foi caracterizada pelo conservadorismo, foi contrário às eleições diretas em $1985 \mathrm{e}$ um fervoroso defensor da pena de morte para crimes de sequestro, roubo e estupro que resultassem em morte.

No segundo semestre de 2016, por indicação do professor Marcos Napolitano, tivemos acesso à tese de doutorado defendida no início do ano pela historiadora Katia Krause, cujo título é "O Brasil de Amaral Netto, o repórter-1968-1985", na qual ela analisa a narrativa audiovisual do Brasil elaborada nas reportagens de toda a série televisiva. Esta minuciosa pesquisa nos deu uma visão mais aprofundada sobre diversos aspectos da trajetória do jornalista, do programa e sobre a história da televisão, da propaganda e da política do país. Mencionaremos alguns dos valiosos aportes que ela nos trouxe.

\footnotetext{
${ }^{4}$ Verbete biográfico. Fidelis dos Santos Amaral Netto http://www.fgv.br/cpdoc/acervo/dicionarios/verbete-biografico/fidelis-dos-santos-amaral-neto
} 
De acordo com a pesquisadora, Amaral Netto fundou uma empresa em 1960, a Plantel-Editora e Publicidade, que produzia e vendia produtos como fascículos, slides, filmes e programas para a TV e cujo produto mais importante era o programa Amaral Netto, o Repórter. Segundo Krause, a Plantel alugava o horário de transmissão junto à Globo. Nesse sentido, a autora aponta que é possível que o programa tenha sido imposto à Rede Globo, assim como também cogita que a entrada de Amaral Netto na Globo se deva a uma sociabilidade construída por ele tanto no campo profissional quanto no campo político. Ela ainda indica que ele e Roberto Marinho, presidente e fundador das Organizações Globo, já tinham um relacionamento profissional e pessoal antes mesmo da inauguração da TV Globo, em 1965. O que se constata é que o programa foi aceito na emissora, que por sua vez não interferia no conteúdo, no formato nem nas opiniões que o jornalista emitia nos programas.

De acordo com Krause (2016: 22) Amaral Netto "parece ter sido movido por forte sentimento patriótico e interessava-se pela história do Brasil". Ele se autodenominou repórter-historiador e mesmo não tendo uma formação específica era reconhecido socialmente como intelectual. Suas reportagens estavam caracterizadas pelo didatismo, pelo uso de mapas e de muita informação histórica.

Um aspecto significativo apontado por Krause (2016:15) é a construção da memória tanto do jornalista quanto da Rede Globo. Segundo a autora, Amaral Netto "é situado como porta-voz da ditadura ou como titular de um programa de televisão imposto à TV Globo", por sua vez, em relação à Globo "se cristalizou uma ideia de que a emissora atuou fazendo lavagem cerebral enquanto a ditadura oprimia a população".

Consideramos importante fazer um breve histórico das Organizações Globo, grupo do qual a Rede Globo faz parte, por não somente ter sido o meio no qual foi veiculado o programa Amaral Netto, mas também, e fundamentalmente, porque foi durante a ditatura civil-militar que a empresa iniciou e consolidou seu poder, foi nessa época que a empresa adquiriu sua colossal dimensão no mundo dos meios de comunicação, e foi durante aquele 
período que a Rede Globo nasceu, prosperou e se expandiu. É disso que nos ocuparemos a seguir.

\subsubsection{Sintonizando nas Organizações Globo}

Fundado em 1925 pelo jornalista Irineu Marinho a direção do jornal $O$ Globo foi assumida pelo seu filho, Roberto Marinho em 1931. Esse foi um dos pontos de partida para o conjunto de empresas chamado Organizações Globo. De acordo com o site Memória Globo, em 1944 foi inaugurada a Rádio Globo do Rio de Janeiro, cujo foco principal era o jornalismo. Tempo depois foram adquiridas outras emissoras e foi formado o Sistema Globo de Rádio. Ainda de acordo com o site ${ }^{5}$ que guarda a memória do grupo:

Sempre atento às novidades no ramo das comunicações, Roberto Marinho inaugurou, em 26 de abril de 1965, a TV Globo, Canal 4 no Rio de Janeiro. Em poucos anos transformou-se na Rede Globo de Televisão; no ano seguinte foi inaugurada a TV Globo São Paulo; em 1968, a TV Globo Belo Horizonte; e no início da década de 1970, foram ao ar emissoras em Recife e Brasília. Com cinco emissoras próprias e 117 afiliadas, a Rede Globo chega atualmente a praticamente $100 \%$ do território nacional, atingindo 5.485 municípios e 99,5 \% da população.

Ainda de acordo com o site, Roberto Marinho admirava o caráter de Castello Branco e manteve um bom relacionamento com Ernesto Geisel e com João Baptista Figueiredo. O bom relacionamento do empresário com o governo e o apoio dado ao golpe de 1964 está plasmado na primeira página de O Globo do dia 2 de abril de 1964 em editorial cujo título é "Ressurge a Democracia!":

${ }^{6}$ Vive a Nação dias gloriosos. Porque souberam unir-se todos os
patriotas, independentemente de vinculações políticas, simpatias ou
opinião sobre problemas isolados, para salvar o que é essencial: a
democracia, a lei e a ordem. Graças à decisão e ao heroísmo das
Forças Armadas, que obedientes a seus chefes demonstraram a falta
de visão dos que tentavam destruir a hierarquia e a disciplina, o Brasil
livrou-se do Governo irresponsável, que insistia em arrastá-lo para
rumos contrários à sua vocação e tradições. ... Salvos da comunização

\footnotetext{
${ }^{5}$ Roberto Marinho

http://memoria.oglobo.globo.com/perfis-e-depoimentos/roberto-marinho-9055075

${ }^{6}$ Os dias Gloriosos da Globo e da ditadura

http://averdade.org.br/2016/04/os-dias-gloriosos-da-globo-e-da-ditadura/
} 
que celeremente se preparava, os brasileiros devem agradecer aos bravos militares, que os protegem de seus inimigos.

Na década dos 70, com o acesso massivo aos aparelhos de televisão, os programas veiculados pela Rede Globo se transformaram em modelo de diversão e também de comportamento, principalmente através das novelas que ditaram padrões de relacionamento, de linguagem e moda. De acordo com Fausto e Devoto (2004: 434)

Os programas da Globo foram, também, um poderoso instrumento informativo ou desinformativo que nada teve de isento, pois a emissora sempre esteve colada à visão governamental ou próxima a ela, quaisquer que tenham sido as mudanças ocorridas no âmbito sociopolítico.

Veremos a seguir, como a Globo foi adotando uma perspectiva diferente em seu discurso relacionado ao período do regime, e como a empresa lidou e lida com os programas que foram produzidos apoiando claramente a intervenção militar de 1964.

\subsubsection{Cid Moreira, a voz do Jornal Nacional e (Des)memória Globo}

No filme a voz em off que narra os acontecimentos mostrados nas imagens é a inconfundível voz de Cid Moreira, o apresentador e âncora do Jornal Nacional, na Rede Globo, no período de 1969 até 1996, sendo também o locutor de algumas reportagens especiais exibidas no Fantástico. A narração dele em Brasil de Ontem, Hoje e Amanhã é também "um indício do grau de envolvimento da emissora com o projeto autoritário, porque o locutor era, já então, e por 27 anos, na bancada do telejornal, uma das marcas mais reconhecidas e identificadas no país com a TV Globo" (Krause, 2016: 255). A voz de Cid Moreira é especialmente familiar para o público brasileiro, pois 0 Jornal Nacional foi durante muitos anos o telejornal com maiores índices de audiência. 
Apesar de termos certeza de que a narração foi feita por Cid Moreira, deparamo-nos no filme Brasil de Ontem, Hoje e Amanhã com alguns aspectos que nos parecem relevantes porque dizem respeito ao quadro enunciativo e à memória. O documentário, filmado inteiramente em preto e branco, tem um corte abrupto no final e, na hora de apresentar a ficha técnica a música muda, a imagem fica colorida e aparecem os créditos e a ficha que do que, ao que tudo indica, é um outro filme. Constam nos créditos textos que não estão no documentário, que seriam citações de Fernando Sabino, Antônio Silva Alvarenga e Carlos Drummond de Andrade, lidas pelo ator Rubens de Falco. Também estão os nomes do diretor de fotografia André Palluch, de Nilton Valério como narrador, e de Olívio Tavares de Araújo como diretor e roteirista. Fizemos uma busca e encontramos vários filmes realizados por esse diretor, muitos dos quais são documentários sobre arte produzidos pela Agência Nacional na década de 1970.

Isto significa que os nomes, as identidades e as vozes que estão presentes no filme não estão na ficha técnica. Para poder verificar essas informações, entramos em contato com a Rede Globo, através da seção Memória Globo, solicitando mais informações. A resposta que recebemos foi que o material, que está com o selo do Arquivo Nacional, não se encontra no acervo da emissora. Enviamos outro email solicitando a possibilidade de verificar no arquivo da programação da Rede Globo a data e o horário de transmissão do programa no qual o filme foi veiculado, mas, a Equipe de Conteúdo Globo, nos deu a seguinte resposta:

\section{Olá, Andrea!}

Realizamos uma pesquisa em nosso acervo e não encontramos o material solicitado. Esperamos que consiga encontrar por meio de outras fontes.

Att. Equipe Conteúdo Globo

Parece-nos muito relevante a ausência de informações, principalmente a sugestão dada pela Equipe Globo de Conteúdo de procurar outras fontes, o que significa de certa forma uma recusa em assumir a sua veiculação. $O$ apoio e a divulgação que o Grupo Globo deu ao o regime militar são públicos e assumidos, a empresa foi bastante generosa com as autoridades do governo 
naquele período, principalmente no Jornal Nacional. De acordo com Krause (2016:49) "a TV Globo é apontada quase unanimemente como a principal beneficiária na área de comunicação". A autora ainda afirma:

Da mesma forma, é importante compreender porque hoje, também a TV Globo, busca insinuar um discurso de resistência possível durante a ditadura, amparando-se, em sua construção de memória, no fato de ter acolhido e dado voz aos agentes de produção cultural identificados com as esquerdas, além de ter lidado com uma censura muitas vezes implacável. Apenas recentemente o jornal $O$ Globo admitiu em editorial autocrítico que a opção de apoio ao golpe de 64 foi um erro" (Krause, 2016:49)

Nesse sentido, acreditamos que a resposta que a Equipe Globo de Conteúdo nos deu contraria as declarações feitas no site Memoria Globo ${ }^{7}$, mas também é coerente com a memória da resistência possível mencionada acima:

\section{DE MARÇO DE 1964}

Apoio ao golpe de 64 foi um erro

Diante de qualquer reportagem ou editorial que thes desagrade, é frequente que aqueles que se sintam contrariados lembrem que $O$ GLOBO apoiou editorialmente o golpe militar de 1964.

A lembrança é sempre um incômodo para o jornal, mas não há como refutá-la. É História. O GLOBO, de fato, à época, concordou com a intervenção dos militares, ao lado de outros grandes jornais, como "O Estado de S.Paulo", "Folha de S. Paulo", "Jornal do Brasil" e o "Correio da Manhã", para citar apenas alguns(...)

A lembrança parece ser um incômodo para o Grupo Globo, mas embora tenha declarado que não há como refutar essa lembrança, ele está negando possibilidade de abrir seus arquivos, se recusando a lembrar seu posicionamento institucional diante da ditadura, contrariando mais uma vez as suas próprias declarações:

[...] 8 Contextos históricos são necessários na análise do posicionamento de pessoas e instituições, mais ainda em rupturas institucionais. A História não é apenas uma descrição de fatos, que se sucedem uns aos outros. Ela é o mais poderoso instrumento de que o homem dispõe para seguir com segurança rumo ao futuro: aprende-se com os erros cometidos e se enriquece ao reconhecê-los.

Ainda na tentativa de obtermos mais informações entramos em contato com o Arquivo Nacional, que guarda desde o início dos anos 80 o material da

\footnotetext{
7 http://memoria.oglobo.globo.com/erros-e-acusacoes-falsas/apoio-ao-golpe-de-64-foi-um-erro-12695226

${ }^{8} \mathrm{http} / / / \mathrm{mem}$ ria.oglobo.globo.com/erros-e-acusacoes-falsas/apoio-ao-golpe-de-64-foi-um-erro-12695226
} 
Agência Nacional, porém, a resposta que obtivemos é que versão do filme que o Arquivo possui é a mesma que está no site, portanto que não há no Arquivo informações complementares sobre sua realização.

Foi através da pesquisa realizada por Krause (2016), que obtivemos dados importantes: o filme foi veiculado em um programa especial, provavelmente por isso não aparece nem a imagem nem a voz de Amaral Netto, o documentário é mencionado em uma notícia de jornal como sendo parte das comemorações da Semana do Exército de 1975 (no mês de agosto), mas sem mencionar o jornalista.

O "documentário" Brasil de Ontem, Hoje e Amanhã teria sido entregue ao comandante do II Exército, Eduardo D’Ávilla Melo, pelo presidente do Banco do Estado de São Paulo, Murilo Macedo, com a finalidade de mostrar "a contribuição das Forças Armadas para a tranquilidade alcançada pelo país a partir de 1964"”. (Krause, 2016:254)

Consideramos assim dar por encerrada a nossa busca por mais informações sobre o documentário brasileiro, em nossa análise consideramos tanto as fontes apresentadas no filme como aquelas que foram ocultas, tais como a participação de Cid Moreira e outras que foram apagadas. Este ocultamento parece-nos relevante e significativo.

Veremos a seguir como com relação ao filme argentino também tivemos dificuldades em localizar fontes, data e horário de veiculação, assim como dados sobre a produção do documentário.

\subsection{Si te he visto no me acuerdo}

Com relação a Ganamos la Paz, embora tenhamos a ficha técnica não pudemos avançar e coletar dados sobre sua produção e sua veiculação. Encontramos uma matéria publicada no jornal argentino Página $12^{9}$ onde consta que o filme foi veiculado no Canal 7 TVP (Televisión Pública) da Argentina, mas não sabemos a data, o horário da veiculação e se o filme foi

\footnotetext{
${ }^{9}$ Apuntes para la memoria

http://www.pagina12.com.ar/diario/suplementos/espectaculos/9-24630-2012-03-17.html
} 
apresentado em uma única ocasião ou em várias. Entramos em contato com a TVP para verificar a informação, mas não obtivemos resposta.

Pretendíamos localizar essas informações nos arquivos da TVP e ou da Biblioteca Nacional em Buenos Aires. Nesta última procuramos a programação de TV de 1977 publicada no jornal El Clarín. Na nossa busca verificamos que a grade de televisão da época era muitas vezes decidida no momento da exibição, era frequente encontrar no jornal um horário com a indicação "film a designar". Por outro lado pensamos também que é possível que o filme tenha sido veiculado durante o horário do noticiário sem ter sido previamente anunciado. Também entramos em contato com a TVP para saber se existia nos arquivos da emissora a programação daquele período, mas, de acordo com o pessoal da seção de Arquivo do canal essa informação não existe. Embora a nossa busca não tenha nos levado à informação que buscávamos, acreditamos que essa ausência de dados é também muito significativa e nos remete também a um apagamento da memória. Esse apagamento está presente no site da TVP, onde o filme está também catalogado, não a versão completa, mas um trecho. A seção onde o trecho do filme se encontra tem um nome bem significativo: "Si te he visto no me acuerdo". Trata-se de um ditado popular que pode ser utilizado em várias circunstâncias e que está relacionado ao esquecimento intencional por alguma razão que pode se referir ao sentimento de vergonha por alguma coisa que aconteceu e que é melhor esquecer, assim como também à falta de agradecimento ou de reconhecimento de algo ou alguém. A seção da TVP ${ }^{10}$ é descrita assim:

Imágenes que no vimos, que quizás no recordamos pero volveremos a ver, con el particular enfoque y sensibilidad del historiador Felipe Pigna. Hitos, hechos, anécdotas, conquistas y tragedias de nuestra historia alojados en nuestra memoria, para que volvamos a recordar y emocionarnos.

A publicação de um trecho do filme Ganamos la Paz no site está acompanhada da seguinte resenha ${ }^{11}$ :

Ganamos la Paz es un documental que, a modo de propaganda oficial de la Junta Militar, celebra el accionar político, económico y social

\footnotetext{
${ }^{10} \mathrm{Si}$ te he visto no me acuerdo

http://www.tvpublica.com.ar/programa/si-te-he-visto-no-me-acuerdo/

${ }^{11}$ Ganamos la paz

http://www.tvpublica.com.ar/articulo/documental-de-la-dictadura-civico-militar-ganamos-la-paz-1977
} 
llevado adelante durante la última dictadura cívico-militar. La película construye un relato en el que las FFAA muestran su visión de la historia, justificando el terrorismo de Estado que sentó las bases del orden económico y social neoliberal en nuestro país.

Incorporamos a falta de informações para levantar outras questões sobre nosso documentário. Sabemos que os militares, antes de o regime cair em dezembro de 1983, se ocuparam de destruir arquivos e provas em uma tentativa de apagar da memória os registros das atrocidades cometidas naqueles anos. No entanto, muitos documentos foram encontrados, graças ao investimento realizado especialmente a partir de 2003, primeiro durante 0 governo de Nestor Kirschner e posteriormente o de Cristina Kirschner, período no qual se reabriram os processos judiciais e foram julgados e condenados membros das forças armadas e participantes e colaboradores do terrorismo de estado. Graças às políticas de memória os anos do último regime militar argentino foram revisitados, pesquisados e analisados sob vários aspectos. Foram disponibilizados na internet arquivos, fotos, documentos e pesquisas diversas relacionadas àquele período. Buscando informações mais precisas, que finalmente não conseguimos, obtivemos algumas pistas sobre as quais fizemos algumas hipóteses que lamentavelmente não poderemos comprovar, mas que consideramos importantes na tentativa de compreender as condições de produção de Ganamos la Paz.

\subsubsection{Suposições e questionamentos sobre a produção de Ganamos la $\mathrm{Paz}$}

De acordo com matéria publicada no jornal argentino Página12 em outubro de 2014, ${ }^{12}$ foram achados em um escritório Militar da Argentina na África do Sul documentos e rolos de filmes de características semelhantes às de Ganamos la Paz. Esses filmes estariam divididos em bloques temáticos. Em alguns deles, executivos de grandes empresas multinacionais, religiosos e representantes da sociedade teriam dado testemunho, emprestando sua voz e sua imagem para afirmar que na Argentina os direitos humanos eram

\footnotetext{
${ }^{12}$ El archivo sudafricano

http://www.pagina12.com.ar/diario/elpais/1-256867-2014-10-05.html
} 
respeitados e que havia estabilidade no país. Consideramos que o documentário argentino pode fazer parte dessa série de filmes propaganda realizados com a colaboração da agência de publicidade norte-americana Burson Marsteller, para a qual o regime encomendou uma pesquisa de imagem entre 1976 e 1977.

Pela descrição que a matéria do jornal Página 12 apresenta, alguns ou um desses filmes contêm fragmentos do nosso objeto de estudo:

En la película, el off construye un relato cronológico. $Y$ la violencia se expandió por el país. Corrientes, Tucumán, Córdoba, Rosario, Buenos Aires. Se habla de Aramburu. Y de los sucesos atribuidos a las organizaciones armadas.

Aparentemente havia um interesse por parte do regime em melhorar a sua imagem frente à comunidade internacional. Uma das razões pode ser a proximidade da copa do mundo de futebol que se realizaria na Argentina em 1978. Também é preciso considerar que já havia denúncias das violações aos direitos humanos na Argentina, denúncias de alguns ex-prisioneiros que relataram e divulgaram a existência dos centros clandestinos de detenção, da tortura e dos assassinatos que eram cometidos. Setores da sociedade civil também começavam a se organizar, é o caso das Madres e das Abuelas de Plaza de Mayo, que com as suas rondas às quintas feiras na praça, tradicional e histórico palco dos grandes acontecimentos políticos do país, reclamava informações sobre o paradeiro de seus filhos e netos. Outro fator a considerar é que com James Carter assumindo a presidência dos EUA em janeiro de 1977, a política exterior dos EUA muda e o país deixa de dar o apoio explícito que dera às ditaduras da América Latina, o regime argentino estava perdendo credibilidade e estava sendo questionado internacionalmente.

Portanto, podemos pensar que o regime precisava se legitimar no plano internacional, inclusive por causa de sua situação econômica e da necessidade de se relacionar com o capital estrangeiro que a política neoliberal adotada requeria.

Uma das hipóteses que cogitamos é que Ganamos la Paz, possivelmente tenha sido feito nesse mesmo pacote mencionado na matéria do Página 12, mas para ser exibido para o público interno, dentro da Argentina. 
Também pensamos que trechos desses filmes podem ter sido enxertados em outros documentários institucionais produzidos para o regime.

\subsubsection{Memória oculta}

Consideramos muito significativos vários aspectos relacionados à memória com os quais nos deparamos. As lacunas de informação nos fizeram notar como os filmes permanecem semiocultos em cada país. Com relação ao documentário brasileiro, sabemos qual a instituição que o produziu, em qual programa foi veiculado e em qual emissora de tv. No entanto, a adulteração acidental ou intencional dos créditos nos leva a pensar que há aspectos que foram, propositalmente ou não, deixados de lado, esquecidos. Também o fato de a Rede Globo não nos fornecer as informações solicitadas nos leva a supor que há uma intenção de ocultamento, ou pelo menos uma falta de interesse da emissora em investir recursos de pesquisa para investigar em seus arquivos a identidade do filme.

Com relação ao documentário argentino, a ficha técnica com o nome de uma produtora (JHC y Asociados) que tentamos localizar sem sucesso, bem como o nome do roteirista, do editor e do diretor a respeito dos quais não conseguimos mais nenhuma informação, nos levam a crer que houve um ocultamento deliberado com relação a produção do filme, assim como sobre sua veiculação.

\subsubsection{Construindo com a memória}

No caminho que percorremos em busca de informações sobre Brasil, Ontem, Hoje e Amanhã e Ganamos la Paz encontramos lacunas, essa memória apagada também nos revela o percurso que as instituições de cada país fizeram desde a redemocratização. É sobre esse percurso que nos debruçaremos a seguir. 
De acordo com Beatriz Sarlo, em alguns países da América Latina "quando acabaram as ditaduras, lembrar foi uma atividade de restauração dos laços sociais e comunitários perdidos no exílio ou destruídos pela violência de Estado". (Sarlo, 2007:45). Na Argentina, imediatamente depois da restauração da democracia, lembrar havia se tornado uma atividade institucional. Apenas cinco dias depois de ter sido eleito, em dezembro de 1983, o presidente Raúl Alfonsín decretou o julgamento das Juntas Militares, que haviam tomado o poder em 1976, e criou a CONADEP (Comisión Nacional sobre la Desaparición de Personas), que elaborou um dos primeiros registros institucionais das graves violações aos direitos humanos ocorridas no país. Com algumas limitações, o relatório Nunca Más teve como um dos principais resultados demonstrar que a desaparição forçada de pessoas existiu, que não haviam sido casos isolados, mas sim um plano sistemático de extermínio. O país inaugurava um período no qual as políticas de "Memoria, Verdad y Justicia" foram de grande importância. Esse tripé agiu sobre a produção de fatos de justiça e sobre visões e percepções da população em geral sobre o acontecido naqueles anos, bem como sobre suas valorizações em torno dos direitos humanos.

Com muitas idas e vindas, julgamentos e leis de indultos, foi em 2003, que o então presidente da Argentina, Nestor Kirschner, revogou a lei chamada Punto Final, que havia paralisado os processos judiciais contra os repressores, e levou a memória e a verdade à instância jurídica, responsabilizando e julgando os autores de crimes de lesa humanidade cometidos sob o comando das juntas militares. Com a reabertura dos processos, uma série de documentos e registros daquele período foi resgatada e foi disponibilizado na internet material que os militares não conseguiram destruir; são registros e documentos elaborados na época pelas forças de segurança. Graças a essas políticas de memória é que tivemos acesso a outros textos que fazem parte do nosso arquivo.

No Brasil, as coisas aconteceram de forma muito diferente. Decretada pelo último presidente da ditadura militar João Baptista Figueiredo a lei ํo 6683 concedeu: 
[...] anistia a todos quantos, no período compreendido entre 02 de setembro de 1961 e 15 de agosto de 1979, cometeram crimes políticos ou conexo com estes, crimes eleitorais, aos que tiveram seus direitos políticos suspensos e aos servidores da Administração Direta e Indireta, de fundações vinculadas ao poder público, aos Servidores dos Poderes Legislativo e Judiciário, aos Militares e aos dirigentes e representantes sindicais, punidos com fundamento em Atos Institucionais e Complementares. ${ }^{13}$

Promulgada por um presidente que não havia chegado ao poder pelas vias democráticas, sob o lema "Anistia ampla, geral e irrestrita", a lei, em outras palavras, colocou uma espécie de ponto final sobre os crimes cometidos naquele período, uma proposta de impunidade, de esquecimento do passado, de não mexer nas feridas. Naquele contexto de ditadura a lei de anistia fazia sentido, afinal um presidente militar estava anistiando de um lado, militantes e exilados, e do outro, as forças armadas, as forças policiais e os grupos paramilitares pelos crimes cometidos durante o período no qual o país esteve sob a autoridade deles. Embora a lei de anistia não devesse ser indiscriminada nem indiferenciada, mas sim um instrumento de consolidação da democracia, que deveria determinar culpas e responsabilidades e punir os responsáveis pelas atrocidades cometidas (Endo, 2012:102) o que aconteceu foi que a lei de anistia se apresentou como um instrumento jurídico de esquecimento e perdão.

Com a volta da democracia, e mais especificamente com os mandatos do presidente Luiz Inácio Lula da Silva e (2003-2011) e da presidenta Dilma Rousseff (2011-2016) ${ }^{14}$, apesar das limitações no plano da justiça, lentamente recuperou-se a memória e houve avanços importantes como a criação da Comissão Nacional da Verdade (CNV) e a publicação do Relatório Final, a criação de centros de pesquisa em universidades e publicações em sites que disponibilizam arquivos e documentos que até há pouco tempo permaneciam desconhecidos. Os trabalhos da CNV foram de extrema importância para a recuperação da memória. Lembremos que a CNV convocou e colheu, em 2013, o depoimento do coronel reformado Carlos Brilhante Ustra, comandante do

\footnotetext{
${ }^{13}$ Lei de Anistia

http://www.planalto.gov.br/ccivil 03/leis/L6683.htm
}

\footnotetext{
${ }^{14}$ A presidenta Dilma Rousseff foi destituída do seu cargo em agosto de 2016 por um golpe articulado pelos setores mais conservadores do país.
} 
Destacamento de Operações de Informações-Centro de Operações de Defesa Interna do 2ํㅡㄹ Exército em São Paulo (DOI-Codi/SP), entre 1970 e 1974. O coronel Ustra tornou-se o primeiro militar a ser reconhecido pela Justiça como torturador durante a ditadura. No entanto, em abril de 2015 o Supremo Tribunal Federal (STF) suspendeu uma das ações penais contra Ustra, pois considerou necessário aguardar o julgamento da Lei de Anistia. O coronel Ustra faleceu em 2015 e não foi condenado em última instância, o processo ficou "parado" na justiça.

Ainda existem espaços e informações restritas, pois as autoridades militares diante de qualquer pedido de informação mantêm silêncio ou dizem "não há nada para comentar".

Com a publicação do Relatório Nacional da Comissão da Verdade, de alguma forma, resgatou-se a memória e a verdade. No entanto, no plano da justiça houve em 2010 o julgamento da lei pelo Supremo Tribunal Federal no qual foi confirmada a anistia aos torturadores e assassinos que atuaram durante a ditadura.

Como nosso propósito é ao comparar e analisar esses dois documentários, verificar que relação poderíamos encontrar entre aspectos da configuração enunciativa e as condições de produção das quais eles surgem, faremos uma breve consideração sobre a chegada dos militares ao poder em cada país.

\subsection{Os regimes militares}

Faremos uma breve descrição da implantação dos regimes militares porque consideramos aquele momento como central, eles são o acontecimento que suscitou a nossa pesquisa, são a referência temporal, histórica e discursiva de nosso estudo. Suscintamente indagaremos como se deu o processo histórico de implantação dos regimes em cada país. 
É importante ressaltar que nessa breve descrição do golpe de 1964 no Brasil, percorreremos 11 anos de ditadura até a atualidade do filme, que se veiculou em 1975. Passaremos por quatro momentos do regime militar de Castelo Branco a Geisel, portanto o momento pós golpe ocupa grande parte da narrativa do filme brasileiro.

Ganamos la Paz foi realizado e veiculado em 1977, ou seja, no ano seguinte ao golpe, está centrado na narrativa da situação do país antes do golpe. A intervenção das forças armas surge nos últimos minutos do filme, por isso descreveremos apenas um período imediatamente anterior à tomada do poder e o primeiro ano do regime militar argentino.

\subsubsection{Regime militar na Argentina (1976-1983)}

Em 1973, com a volta da democracia depois do regime militar anterior (1966-1973), assume a presidência Hector Cámpora, que logo depois renuncia para viabilizar a candidatura do ex-presidente Juan Domingo Perón, quem assume a presidência em outubro de 1973. De acordo com Novaro e Palermo (1996:28) a volta de um governo constitucional estava acompanhada por expectativas muito diversas por parte de diferentes setores sociais e políticos, uma dessas expectativas era que podia haver na Argentina uma transformação social, uma mudança radical das relações de poder, o cancelamento definitivo do "modelo capitalista e dependente".

Sin duda, para muchos esta esperanza de cambio estaba centralmente depositada en el peronismo. Pero él era el canal de expresión de los intereses sociales y políticos más diversos, incluidos también a los que se oponían a rajatabla a cambios de ese tipo. Frente a la intensa movilización social y la amenazante guerrilla, militares y conservadores arrinconados podían ver en Juan Domingo Perón la tabla de salvación del orden, el único capaz de frenar una mutación revolucionaria. La meta de constituir una barrera eficaz contra el comunismo, argumento que tan fútilmente el propio Perón había invocado ante esos sectores en los años cuarenta, ganaba audiencia en ellos y en las propias filas del movimiento ahora que la "amenaza comunista" parecía finalmente hacerse presente. (Novaro e Palermo, 1996:28) 
O peronismo abrigava setores antagônicos, paradoxalmente havia modos de ação amplamente compartilhados entre esses grupos de direita e de esquerda. Eles adotaram um modo de ação incongruente com as necessidades da democracia, um estilo descrito por Novaro e Palermo(1996:29):

[...] fundado en vocaciones totalizantes y en la disposición a emplear cualquier medio para ponerlas en práctica: la tendencia de percibir toda diversidad como antagónica, y a inscribir toda acción propia y ajena en la lógica amigo-enemigo son rasgos centrales del clima político-cultural en que se iría gestando el irremediable fracaso de esa experiencia.

Perón estava muito próximo e influenciado pelo ministro do Bem-estar social, José Lopez Rega, "El Brujo". Lopez Rega foi estruturando um trabalho sistemático de persecução e extermínio de setores opositores, através de ações da Triple A, Aliança Anticomunista Argentina, que por sua vez, contava com a cumplicidade das forças armadas. A guerrilha reage e o clima de violência se acentua ainda mais quando Perón morre, em julho de 1974. Assume a presidência sua esposa, María Estela Martinez, Isabelita, com a forte influência do ultradireitista Lopez Rega no cargo de ministro. O cenário econômico mundial e nacional foi se deteriorando. De acordo com Novaro e Palermo (1996:17), a inflação estava em níveis galopantes - de março de 1975 a março de 1976 a alta de preços chega a 566\%. As tentativas de controle inflacionário foram fracassando e o cenário na Argentina é de violência política, crise institucional e fracasso econômico. Em fevereiro de 1976, as forças paramilitares chegam a cometer mais de 100 assassinatos, causando terror na população, prática característica do regime argentino que ostentava o poder paralelo ao fazer circular seus homens em seus carros Ford Falcon mostrando suas armas para a população.

No dia 24 de março de 1976 as forças armadas tomam o poder com uma junta militar composta pelo exército, a aeronáutica e a marinha, representadas respectivamente pelo Tenente General Jorge Rafael Videla, pelo Brigadeiro Orlando Agosti e pelo Almirante Eduardo Massera. Anunciam através dos meios de comunicação que a Junta de comandantes colocara fim ao agônico exercício das autoridades civis e assumia o poder político em nome do autodenominado "Proceso de Reorganización Nacional". As primeiras 
medidas da Junta foram ${ }^{15}$ : suspensão da atividade política, intervenção nos sindicatos, dissolução do Congresso, dissolução dos partidos políticos, destituição da Corte Suprema de Justiça, proibição de greves e de reivindicações de direitos coletivos de trabalho, suspensão da vigência do Estatuto do Docente, fechamento de centenas de locais noturnos, queima de milhares de livros e revistas considerados subversivos, censura nos meios de comunicação. Naquele mesmo dia tropas militares ocuparam fábricas, houve sequestros e centenas de detenções de sindicalistas, políticos, jornalistas e intelectuais, "inimigos ativos" e de aqueles considerados suspeitos, muitos deles desaparecidos até hoje. Os historiadores Novaro e Palermo (1996:22) afirmam:

Se trataba de dejar sentado desde un principio y de modo taxativo que las Fuerzas Armadas no se proponían tan sólo terminar con un gobierno, misión casi irrelevante tratándose de una administración que yacía moribunda a sus pies desde hacía meses, sino, en sus palabras, poner en vereda a una sociedad sumida en el caos. Y que para curarla de sus males, que la convertían en una presa fácil de la subversión, se impondría una vigilancia escrupulosa y un disciplinamiento definitivo a todos los sectores políticos y sociales (con especial rigor a quienes, según los golpistas, debían expiar las culpas por el caos y el desgobierno) sin miramientos de ningún tipo y teniendo en vista, como diría poco después un jerarca militar "objetivos y no plazos". (Novaro e Palermo 1996:22)

Assim teve início o governo mais violento da história argentina. Todo aquele que não estivesse alinhado com as posições do Proceso poderia ser considerado um subversivo e todo subversivo precisava ser disciplinado. Para colocar em prática esta disciplina instalou-se o terrorismo de estado que levaria o país a um dos capítulos mais sangrentos, dramáticos e obscuros de sua história.

Outros autores como Lvovich e Bisquert (2008) também observam como as forças armadas se colocaram no papel de "salvadoras" de uma nação que se encontrava no "caos" causado pelo "flagelo da subversão" que deixara a sociedade doente. As forças armadas se apresentam como a única instituição que está livre desse flagelo, incorrupta e incontaminada e que é capaz de

\footnotetext{
${ }^{15}$ La dictadura militar en Argentina 24/03/1976 a 10/12/1983 http://www2.me.gov.ar/efeme/24demarzo/dictadura.html\#cabeza
} 
"restablecer la vigencia de los valores de la moral cristiana, de la tradición nacional y de la dignidad del ser argentino". (2008:16) (Junta Militar, 1980).

O papel que as forças armadas se deram nesse processo também é mencionado por Novaro e Palermo:

[...] una institución había permanecido incorrupta y sana en el medio de la debacle: las propias Fuerzas Armadas. Sólo ellas podían, al mismo tiempo, erradicar la enfermedad y sus consecuencias. Según este delirio institucionalizado, el virus subversivo respondía en esencia a causas externas, era "extraño al ser nacional" y a sus tradiciones; pero la sociedad no podía - enferma como estaba - defenderse de él por si sola" (1996:34)

O momento do golpe na Argentina já anunciava o terrorismo de estado como uma das características principais do Proceso de Reorganización Nacional. De acordo com Calveiro (2013:41) "entre 1976 e 1982 funcionaram na Argentina 340 campos de concentração/extermínio, distribuídos por todo o território nacional". Calcula-se que passaram por eles entre 15 e 20 mil pessoas, das quais aproximadamente $90 \%$ foram assassinadas. O regime militar inaugurado em 1976 apresentou mudanças na forma de exercer o poder:

O golpe de 1976 representou uma mudança substancial: o desaparecimento e o campo de concentração/extermínio deixaram de ser uma das formas de repressão para se tornarem a modalidade repressiva do poder, executada diretamente a partir das instituições militares. (Calveiro, 2013:40)

Para a autora, o Processo de Reorganização Nacional, ao incorporar essas novas modalidades do aparelho repressivo, que aplicava uma brutal repressão, mostra a atuação institucional das forças armadas. "Ou seja, que as ações "antissubversivas" foram realizadas dentro e a partir da estrutura da cadeia hierárquica das Forças Armadas" (2013:43) (grifos da autora).

Os primeiros anos da ditadura militar na Argentina foram os mais violentos, especialmente 1976 e 1977, período no qual se registrou o maior número de sequestros e desaparecimentos, o país estava sob o auge do terrorismo de estado imposto pelo regime. Grande parte da população argentina estava aterrorizada com a atuação dos chamados "grupos de tareas". 
Esses grupos estavam formados por membros das forças armadas, por membros do corpo de segurança do estado e por paramilitares e para-policiais. Sua função era o sequestro, a tortura, o assassinato e o desaparecimento de pessoas, que de acordo com a lógica do regime, podiam representar um perigo para a sociedade, com a sua atuação ou com a sua influência e com a sua capacidade de "contaminar" os cidadãos de bem com a sua ideologia.

De acordo com Calveiro (2013:38) "Sempre o poder mostra e esconde, e se revela tanto no que exibe quanto no que oculta". O regime militar escondia a existência dos centros clandestinos de detenção e de toda a repressão imposta sem muito empenho, de forma tal que se soubesse da sua existência, muitos operativos se realizavam em plena luz do dia gerando terror e provocando 0 silêncio da população. A autora reafirma: "De fato, para disseminar o terror, cujo efeito imediato é o silêncio e a inação, é preciso mostrar uma fração daquilo que permanece oculto" (Calveiro, 2013:53)

Foi nesse clima de terror generalizado e nesse contexto que o filme Ganamos la Paz foi realizado e veiculado.

\subsubsection{O regime militar no Brasil (1964-1985)}

Com a renúncia de Jânio Quadros em 1961, seu vice, João Goulart, assume a presidência da República. Jango, como era chamado o presidente, havia sido ministro do trabalho do último governo Vargas e não gozava de boa reputação junto aos setores conservadores tanto civis como militares por sua aproximação com os sindicatos. De acordo com esses setores, qualquer movimento de mobilização de massas podia representar o "grande perigo", pois poderia ser o começo de um levante comunista. Nesse sentido, Maud Chiro afirma:

A passagem de "Jango" pelo Ministério do Trabalho sob o segundo governo Vargas, de junho de 1953 a fevereiro de 1954, enraizou tanto a acusação feita a seu respeito de promover uma "comunização" do Brasil quanto o ódio que lhe dispensavam os setores conservadores das Forças Armadas. Desde essa época, ele vem sendo acusado, pela União Democrática Nacional (UDN), a imprensa conservadora e a 
direita militar, de populismo, demagogia e simpatia pela "República sindicalista" peronista da vizinha Argentina . (Chirio, 2012:17)

Segundo Napolitano (2014:17) A virtude do governo Jango foi a de revisar uma agenda política de democratização da cidadania e da propriedade. Nesse sentido, o autor enfatiza que se tratava mais de uma agenda do que de um projeto político.

Jango não tinha base de apoio no Congresso Nacional para aprovar seus projetos, e para tentar resolver esse impasse e conseguir apoio, o presidente apelou para a mobilização das classes populares, o que por sua vez gerou mais descontentamento das classes dominantes. Por outro lado, os movimentos sindicais e populares esperavam que o governo implementasse reformas econômicas e sociais benéficas para eles.

Outro ponto importante é o desequilíbrio causado dentro das forças armadas, que haviam sofrido revolta de subalternos que reclamavam pelas péssimas condições salariais, ocasionando assim a "quebra de hierarquia", fator este que levou a setores que apoiavam Jango a retirar seu apoio. Segundo Chirio, (2012:18):

Independentemente da geração e do grupo a que pertencem, os oficiais golpistas emitem um discurso bastante estereotipado sobre as razões que os levaram a derrubar o poder civil. Enfatizam em especial dois " perigos" principais, contra os quais o golpe teria sido o único e último baluarte: o de uma revolução comunista e o de uma "quebra de hierarquia" nas Forças Armadas por parte dos militares de patente inferior, fomentada por "agentes infiltrados em seu meio - dois perigos que teriam sido tolerados, até mesmo atiçados, pelo presidente João Goulart.

No final de 1963 , com a inflação beirando os $70 \%$, começam a convergir contra o governo os setores mais conservadores, a imprensa se organiza e a conspiração passa a ser a pauta. O historiador Napolitano destaca o papel da imprensa:

Tradicionalmente ligada à linha liberal-conservadora, a grande imprensa brasileira consolidou a leitura de que o país caminhava para o comunismo e a subversão começava no coração do poder, ou seja, a própria Presidência da República.(Napolitano, 2014:46) 
Nesse contexto, um possível golpe da direita seria reativo e "portanto legítima defesa da democracia e dos valores ocidentais e cristãos contra os radicais de esquerda" (Napolitano, 2014:50)

O governo militar contou com o apoio da classe média, para quem a ascensão dos de baixo era vista como uma ameaça. Influenciados pelo discurso anticomunista da imprensa e de várias entidades civis e religiosas, os setores médios acreditaram que Moscou pretendia conquistar o Brasil "ameaçando a civilização cristã, as hierarquias naturais da sociedade e da liberdade individual" (Napolitano, 2014:49)

Outro ingrediente fundamental e decisivo no momento do golpe foi a participação dos EUA e de seu embaixador Lincoln Gordon no Brasil, um dos articuladores da chamada Operação Brother Sam, que ofereceu apoio militar caso houvesse algum tipo de resistência por parte de setores progressistas das forças armadas que se opusessem ao golpe.

Em 31 de março de 1964, o General Olímpio Mourão Filho desencadeia o golpe, organizando uma coluna de soldados que sai de Minas Gerais em direção ao Rio de Janeiro. Jango não opõe resistência, e, no dia 2 de abril, o Congresso declara vacância da Presidência da República. Ranieri Mazzilli, presidente da Câmara dos Deputados assume o cargo interino de Presidente da República, mas já era evidente que se tratava de um cargo de curta duração e com a tutela dos militares. Vários setores e partidos políticos se articulam e surge o nome do General Castelo Branco, que é eleito Presidente da República pelo Congresso Nacional. O Congresso é "saneado" com a cassação de 40 parlamentares, a constituição é suspensa e substituída pelos Atos Institucionais.

Segundo o autor, os conspiradores e os governistas acreditaram que se tratava de um governo de curta duração, no entanto, o Governo Castelo Branco:

[...] ao mesmo tempo que prometia um mandato tampão, nunca escondeu seus objetivos estratégicos - uma política voltada para a acumulação do capital que exigia políticas a longo prazo. (Napolitano, 2014:67). 
O governo do Marechal Humberto Castelo Branco estabeleceu o Ato Institucional n॰1, Al-1 que, entre outras coisas dava poder ao presidente para cassar e suspender poderes políticos de qualquer cidadão que os tivesse, foram cortadas as relações diplomáticas com Cuba, foi criado o SNI, Serviço Nacional de Informações e estabelecida a Lei de Segurança Nacional. Por outro lado, como aponta Napolitano (2014:71)

O regime evitava desencadear uma repressão generalizada, à base de violência policial direta e paralegal, como aquela exigida pela extremadireita militar, sobre tudo contra artistas, intelectuais e jornalistas.

Ainda de acordo com o autor, "os quatro primeiros anos dos militares no poder foram marcados pela combinação de repressão seletiva e construção de uma ordem institucional autoritária e centralista" (2014:71)

Após a saída de Castelo Branco, em março de 1967, os crescentes protestos contra o regime abriram caminho para que assumisse a Presidência um militar linha-dura. A instabilidade cresceu em 1968, passeatas nas ruas, greves e alguns setores da classe média que haviam apoiado o golpe exigiam a reinstalação de um governo civil. Os movimentos estudantis criticavam a repressão dos militares e em março de 1968 o movimento saiu do controle e ganhou as ruas. O estudante Edson Luis foi morto pela polícia em uma manifestação, o que fez crescer a tensão com os estudantes, e houve enfrentamentos entre a polícia e estudantes e populares. Os confrontos, cada vez mais violentos, ganharam mais força depois das revoltas estudantis parisienses. No final de junho houve a passeata dos Cem Mil, uma manifestação contra a ditadura, organizada pelo movimento estudantil com forte apoio da sociedade. Em São Paulo, estudantes da Universidade Mackenzie vinculados ao Comando de Caça aos Comunistas, com o apoio da Guarda Civil, enfrentaram estudantes de esquerda da Faculdade de Filosofia, Ciências e Letras da USP que terminou sendo ocupada pela polícia. Esses episódios deram forças para as lideranças que defendiam a luta armada, como única via para tirar os militares do poder, o que levou a uma radicalização das posições. Grande parte da imprensa passou a ver (e a mostrar) o radicalismo de esquerda como a outra face do radicalismo de direita, inclusive justificando o endurecimento do governo e foi assim que começou a circular a "teoria dos dois demônios". Segundo Napolitano: 
O ano de 1968 no Brasil já foi chamado "o ano que não acabou", expressão que traduz a sensação de interrupção de uma experiência histórica plena de promessas libertárias e que se encerrou, literalmente por decreto, com a edição do famigerado Ato Institucional ํo 5, em dezembro daquele ano.

(Napolitano, 2014: 91)

Através do Al-5 o presidente da República decretou o recesso do Congresso Nacional; interveio nos estados e municípios; cassou mandatos parlamentares; suspendeu, direitos políticos; decretou o confisco de bens considerados ilícitos, e suspendeu a garantia do habeas-corpus. Houve repressão sistemática, perseguição contra estudantes, artistas e intelectuais. Mesmo assim, a esquerda ainda continuava na ofensiva, e em setembro de 1969, depois do sequestro do embaixador americano, a repressão recrudesceu dando início aos chamados "anos de chumbo".

O Congresso seria reaberto em outubro de 1969 para validar a escolha do general Emílio Garrastazu Médici para a Presidência da República. Segundo Fausto e Devoto (2004:405), o governo Médici foi marcado pelo chamado Milagre Econômico, que se deu a partir de uma conjuntura internacional favorável e que trouxe uma grande expansão da economia brasileira. Foi o auge das grandes obras do governo militar: o início da construção da Transamazônica, a assinatura do acordo com o Paraguai para a construção da hidrelétrica de Itaipu, entre outras (Chirio, 2012:168). Houve uma grande expansão do setor industrial e controle da inflação o que proporcionou uma melhora de vida para parte da população. Por outro lado, houve um aumento da máquina repressiva, milhares de pessoas foram processadas e outras presas. Como veremos mais adiante, a máquina repressiva brasileira tinha a mesma base teórica que a argentina: o conceito de "guerra revolucionária" que veio da França. Como lemos em Napolitano (2014:129):

Ela pressupunha a utilização coordenada de todos os recursos militares, políticos e de informação - no combate a um inimigo invisível, oculto - o "subversivo"- entre a população como se fosse um cidadão comum. (Napolitano, 2014:129)

Portanto, contra esse inimigo oculto era preciso abandonar os conceitos tradicionais de guerra, para isso foi desenvolvida uma ação policial, e, como 
parte da esquerda ainda continuava combatente no campo, como por exemplo, no Araguaia, e na cidade, com assaltos a banco e sequestros de diplomatas estrangeiros, foi criada então a Operação Bandeirantes (Oban) em São Paulo, que depois se chamou Comando de Operações de Defesa Interna (CODI), responsável pelas atividades dos Departamentos de Operações e Informações (DOIs). A ilegalidade e a tortura imperavam nos centros clandestinos de detenção e o sistema repressivo elaborou técnicas de desaparecimento dos corpos que eram incinerados ou sepultados anonimamente. De acordo com Napolitano, (2014:127), os setores de oposição sofreram intensa repressão entre 1969 e 1974. Foi durante esse período que surgiram os grupos de extermínio formados pela polícia, como o esquadrão da morte. Foi nessa época que a segurança pública foi militarizada, as polícias militares estaduais ficaram subordinadas ao comando do Exército.

Em março de 1974, assume a presidência Ernesto Geisel. Sob seu governo, de caráter desenvolvimentista, foram inauguradas as primeiras linhas de metrô em São Paulo e no Rio de Janeiro, também foi realizada grande parte da construção da usina de Itaipu. Na política externa o governo Geisel recusou o alinhamento incondicional aos EUA, reconheceu regimes socialistas no mundo e reatou relações diplomáticas com a China. O presidente Geisel passou para história como sendo o responsável pelo processo de redemocratização do país. No entanto há relatos sobre o governo Geisel lembrados por autores como Napolitano que indicam aspectos contraditórios:

Era um autoritário, mas que teria utilizado seu poder autocrático para acabar com o regime militar, que já teria realizado seu papel histórico afastar o reformismo e a ameaçada revolução socialista do horizonte histórico - cumprindo uma espécie de "destino manifesto". (Napolitano, 2014:233)

Seu governo, (Napolitano, 2014:231) "foi um dos mais complexos e dinâmicos do regime militar", cheio de contradições. Sendo um anticomunista convicto reconheceu governos comunistas no mundo contrariando os EUA, usou a censura para controlar a oposição, mas patrocinou uma política cultural que beneficiou muitos artistas que eram contra o regime. Na percepção construída durante seu mandato ele recebeu o reconhecimento pela "chance 
para a democracia", foi Geisel quem revogou os atos inconstitucionais, como o Al-5, reafirmou seu projeto de reabertura política lenta e gradual, afastou os radicais linha dura do governo, daí que há uma identidade quase direta entre Geisel e a abertura. No entanto a ação repressora do regime continuava:

As mortes violentas de militantes de esquerda parecem ser mais obra de um "porão do regime", incontrolável até então, e as cassações, o fechamento do Congresso e as imposições institucionais, meras táticas pra melhor realizar a distensão. Napolitano (2014:233)

Acabamos de expor uma síntese dos processos históricos da chegada dos regimes ao poder, veremos a seguir como o acionar dos dois regimes se deu dentro de um referencial fundamentado na doutrina francesa da "guerre révolutionnaire" (guerra revolucionária). No marco dessa teoria foram elaborados manuais que definiam procedimentos de atuação em vários planos, inclusive manuais de ação psicológica que consideravam a propaganda um instrumento importante e muito eficiente de domínio e disciplinamento da sociedade.

Consideramos que a teoria da "guerra revolucionária" faz parte das condições de produção, na medida em que se estabelecem relações interdiscursivas que nos remetem a esses manuais, tendo em vista que a Análise de Discurso propõe relações sócio-históricas não imediatas com outros textos.

\subsection{A doutrina francesa de "Guerra Revolucionária" nos regimes militares}

Os ocultamentos que detalhamos nos levaram a pensar no aspecto sigiloso da realização dos filmes e a querer indagar alguns possíveis antecedentes em outros materiais que apresentamos a seguir.

No contexto da Guerra Fria já antes da revolução cubana (1959) os dirigentes militares buscaram uma doutrina de guerra que atendesse às suas necessidades. A doutrina militar francesa foi a que predominou nas forças Armadas dos dois países e foi a chamada de "guerra revolucionária". A 
doutrina surgiu no contexto das guerras coloniais que a França travou na Indochina (1946-1954) e na Argélia (1954-1962). Estava fundamentada dentro de um marco teórico e de um conjunto métodos. Partia do pressuposto de que havia uma guerra permanente não declarada entre dois blocos geopolíticos antagônicos: o ocidente capitalista, democrático e cristão e o oriente, comunista, totalitário e ateu (Summo y Pontieri, 2012:287). De acordo com essa perspectiva teórica todo conflito interno que acontecesse em um país alinhado com o bloco ocidental, devia ser enquadrado nesse marco de guerra permanente que se caracterizava por ser uma guerra não declarada, desenvolvida no interior de um Estado e que se dava em todas as esferas da vida nacional. Havia um inimigo interno que se mimetizava entre a população para controla-la. Outro pressuposto fundamental da doutrina francesa era a ideia de que o controle das informações era um elemento decisivo da Guerra Revolucionária, e para isso era preciso combater o inimigo com um comando político militar unificado. Desse modo a doutrina entra no campo das relações civis-militares. (Martins Filho, 2008)

Os métodos elaborados pelos especialistas franceses eram: a subordinação de todas as forças de segurança ao comando das forças armadas e a implantação de medidas de "ação psicológica" e de "guerra psicológica". Também existiam práticas ilegais e criminais que faziam parte dessas medidas antissubversivas, métodos que foram utilizados nos regimes militares dos dois países em maior ou menor grau.

\subsubsection{Processo de importação do terror}

A doutrina francesa de Guerra Revolucionária chegou à Argentina e ao Brasil no final da década de 1950. Segundo lemos em João Roberto Martins filho:

No processo de importação das ideias francesas, o pioneirismo coube à Argentina. Como mostrou Ernesto López, o então coronel Carlos J. Rosas, que acabava de regressar da França, assumiu em 1956 a subdireção da Escuela Superior de Guerra, em Buenos Aires, dando início a um processo de redefinição doutrinária calcado nos 
ensinamentos de veteranos franceses da Indochina e da Argélia. (Martins Filho,2008)

A difusão dessas ideias se deu no caso da Argentina através de viagens para formação de oficiais argentinos às academias militares francesas; da presença de assessores franceses em uma comissão permanente na sede do Estado Mayor del Ejército, cursos e palestras sobre o assunto e da publicação de artigos em revistas de circulação restrita ao Estado Maior. De acordo com os historiadores argentinos Novaro e Palermo (1996:83) oficiais franceses doutrinaram quadros jovens do exército com técnicas antissubversivas, eles consideravam que para enfrentar o comunismo era preciso formar um exército clandestino que trabalhasse paralelamente e de forma oculta articulado com a estrutura oficial. De acordo com os ensinamentos dos experts franceses a luta exigia adotar técnicas acordes com a natureza do inimigo, que implicava:

[...] responder a la subversión en lo que se entendía eran "su mismo terreno y sus mismas armas": desconocimiento de toda convención y toda legalidad, acciones encubiertas de terrorismo, secuestro y asesinato, práctica sistemática de la tortura y extensión del "teatro de operaciones" más allá del combate a los grupos armados y los límites territoriales del país. (NOVARO e PALERMO, 1996:84)

No Brasil, o estudo da "guerra revolucionária" na Escola Superior de Guerra se deu principalmente entre 1957 e 1961, para enfrentar esse "novo" tipo de guerra, dado que a leitura dos militares e de alguns setores das elites era que, com a revolução cubana, tinha chegado a vez da América Latina e o Brasil estaria inserido no quadro da guerra revolucionária mundial. Para os militares, os comunistas planejavam a toma do poder no Brasil, portanto as forças armadas tinham de se preparar contra essa ameaça, conhecendo 0 inimigo, seus métodos e ações. De acordo com Chirio (2012:25)

(..) a partir de 1962, a explanação dos métodos da guerra revolucionária é acompanhada de uma reflexão coletiva sobre as modalidades de seu aprendizado pela oficialidade brasileira: a propaganda, por conseguinte, é pensada, organizada e coordenada, a despeito das reticências do Executivo. (Chirio, 2012 :25)

Segundo Chirio, em 1961 o Estado Maior das Forças Armadas solicita que os termos "guerra insurrecional, guerra revolucionária, subversão, ação 
psicológica, guerra psicológica, e guerra fria”, sejam definidos e a partir daquele ano a doutrina da "guerra revolucionária" começa a ter sua penetração nas escolas militares e nos corpos de tropa. São publicados manuais e ministrados diversos cursos e palestras restritos ao âmbito militar.

O discurso dos meios de comunicação de massa se apoia nos ideais anticomunistas, e depois do golpe de 1964, principalmente a partir de 1967 o discurso da mídia, da elite política e dos militares endurece. Paralelamente o ensino da "guerra revolucionária" se intensifica nas escolas militares nas quais, além da formação teórica, se organiza também a instrução prática. (Chirio, 2012:119).

As publicações sobre a "guerra revolucionária" circulavam nos dois países já na década de 1960, a seguir veremos alguns dos aspectos que os Manuais de Ação Psicológica dos dois países têm em comum.

\subsubsection{Ação psicológica no Brasil e na Argentina}

Enquanto procurávamos informações sobre a existência de diretrizes para a produção de material de propaganda de divulgação massiva encontramos manuais e documentos com uma série de instruções elaboradas pelas forças armadas argentinas. É o caso do livro "Acción Psicológica" do Coronel Jorge Heriberto Poli, cuja edição data de 1958, e de outro manual chamado "Operaciones sicológicas" de 1968, bem como outros manuais e planos produzidos pelo Exército. Nessas publicações é reforçada a determinação do regime de proteger os valores da cultura Ocidental e Cristiana, consolidar o "Ser Nacional" e lutar contra as ideologias de fora impulsadas pelo inimigo subversivo que afetavam a moral e os bons costumes argentinos (Risler, 2011:2).

Também encontramos material análogo de circulação restrita no âmbito militar brasileiro, trata-se de manuais elaborados pelo Departamento de Estudos da Escola Superior de Guerra: "Aspectos da Guerra Contemporânea A guerra revolucionária de 1969, Introdução ao estudo da Guerra 
Revolucionária, de 1959, Conceituação de Guerra Insurrecional, Guerra Revolucionária, Subversão (guerra subversiva), Ação Psicológica, Guerra Psicológica e Guerra Fria"

Os Manuais de Ação Psicológica apresentam uma série de conceituações em comum sobre a guerra revolucionária, a subversão, o sujeito subversivo e sua capacidade de persuasão e de mimetização, bem como dos procedimentos que devem ser realizados para a "ação psicológica". Outro elemento que os manuais compartilham é a necessidade do uso da propaganda como parte importante da "ação psicológica".

Vamos verificar a definição de "guerra psicológica" e de "ação psicológica" nos manuais dos elaborados pelas Forças Armadas dos dois países. De acordo com a publicação do Estado Maior das Forças Armadas (EFMA):

A GUERRA PSICOLÓGICA em sentido geral pode ser caracterizada como a aplicação de partes da ciência chamada Psicologia à conduta da guerra e, em sentido particular, compreende o uso da propaganda contra o inimigo, utilizando-a de tal maneira que possa complementar as operações militares. (os grifos são do EFMA) - (EFMA, 1961:11)

Já no manual elaborado pelo ejército argentino a "ação psicológica" é definida assim:

Acción Sicológica (AS) es un recurso permanente de la conducción que regula el empleo de métodos, procedimientos, técnicas y medios que influyen sobre el campo síquico de determinado público. (Manual RC-5, 1968:8).

Nos dois textos se considera importante a utilização dos meios de comunicação de massa, como jornais, rádio e cinema. É preciso lembrar que o texto brasileiro do EMFA é de 1961, época na qual a televisão ainda estava nos seus primórdios. Veremos a seguir como devia ser implementada a "ação psicológica" de acordo com o manual brasileiro:

As fórmulas de aplicação de Ação Psicológica comportam o acionamento de um certo número de meios e processos técnicos modernos de ação coletiva: imprensa, rádio, cinema e processos que se inspiram, simultaneamente, em métodos de pedagogia ativa e métodos 
de Relações Humanas. Sua principal característica é a de apelar para a participação e a colaboração do indivíduo ao qual elas se dirigem de explicar e fazer compreender diversos aspectos das questões propostas. (EMFA, 1961).

A "guerra psicológica", segundo o manual, se tornou a quarta arma ou a quarta força, haveria portanto, Força Terrestre, Naval, Aérea e Psicológica. A "ação psicológica" corresponde ao emprego da "força psicológica" no sentido:

[...] da população amiga em geral, com a finalidade de fortalecer sua consciência política, de impedir que esqueça os valores morais que estruturam a sociedade em que vive, de lhe fornecer meios eficientes de autodefesa individual e coletiva face à ofensiva da Subversão ou da Guerra Psicológica que sobre ela se desencadear. (EMFA, 1961).

No manual argentino a questão da propaganda também tem um papel relevante:

La propaganda se empleará para comunicar mensajes específicos a un público determinado, constituyendo el medio eficaz cuando se lo emplee para explotar actitudes y opiniones ya existentes que puedan, eventualmente, motivar al público para que este responda en forma inmediata a aquella persuasión o compulsión (Manual RC-5-2,1968)

Também se explicita a finalidade da propaganda, que seria obter e manter a atenção do público, estabelecer sua credibilidade e ainda influenciar suas emoções e atitudes para conseguir o comportamento desejado em um momento específico. O texto também ressalta a importância da televisão como sendo um dos meios de persuasão mais eficazes e vantajosos para as operações psicológicas e por considerar que pode influenciar em uma escala jamais alcançada por qualquer outro meio de comunicação.

Entre as vantagens do uso de material audiovisual mencionadas no manual argentino estão: a possibilidade de usar o dramatismo para criar um clima de realismo, de criar a identificação com os atores por parte do público e de obter da atenção desse público, com ênfase nos analfabetos. Também se destaca a versatilidade dos efeitos especiais dos filmes, até mesmo o uso de desenhos animados para explicar acontecimentos complicados de uma forma compreensível. 
No manual argentino se faz uma classificação da propaganda, ela poderia ser branca, cinza ou preta. A propaganda branca é aquela cuja fonte seria conhecida e que seria amplamente divulgada, a propaganda cinza não seria identificada por sua fonte "dejándose esto librado a la imaginación del público al cual se dirige", por último a propaganda preta é aquela que pretende aparecer como originária de uma fonte que não é a verdadeira. Nesse sentido, consideramos que o filme Ganamos la Paz pode se enquadrar tanto na classificação da propaganda cinza quanto da preta. Poderia ser cinza porque, apesar de haver créditos e ficha técnica completa, não é possível determinar a sua verdadeira fonte, que fica livrada à imaginação do público. Também pode se enquadrar na denominada propaganda preta porque é provável que as fontes citadas não sejam as verdadeiras.

Utilizamos os manuais produzidos pelas forças armadas dos dois países, não como instrumento de análise, mas sim como instrumento para análise, porque eles explicam a necessidade de produzir propaganda para complementar as operações militares e porque explicitam a necessidade dos regimes de utilizar os meios de divulgação de massa como parte da estratégia de comunicação institucional na luta contra o avance da subversão e no controle da população.

A "Guerra Revolucionária, a Guerra Subversiva e a Guerra Psicológica", são uma das justificativas para a ocupação do espaço político das duas forças armadas. Nesse sentido, Martins Filho descreve:

Em exércitos como os da Argentina e do Brasil nos anos de 1950, envolvidos cada um à sua maneira na criação de uma ideologia militar abrangente e ambiciosa, caía como luva o exemplo francês dos intelectuais militares que pensavam por conta própria, em pé de igualdade com seus colegas e aliados civis, que de resto nunca faltaram. Não menos importante, o romantismo e a mística quase religiosa que acompanhavam a doutrina francesa também funcionaram como atrativo adicional para oficiais em busca de uma missão para seus exércitos, no apogeu da Guerra Fria. (MARTINS FILHO, 2008)

Consideramos que os manuais elaborados pelas forças armadas no Brasil e na Argentina explicam ou justificam, de certa forma, a realização dos documentários que analisamos. Ali estão delineados os planos de "Ação 
Psicológica" que serão executados, incluindo a produção de material de propaganda audiovisual. Como descrevemos neste capítulo, os manuais se fundamentam na mesma doutrina: a de "Guerra Revolucionária, Guerra Subversiva e Guerra Psicológica". Emergida no contexto das guerras coloniais que a França travou com a Indochina (1946-1954) e com a Argélia (19541962), essa doutrina foi elaborada dentro de um marco teórico e de um conjunto de métodos e procedimentos. Partia do pressuposto de que havia uma guerra permanente não declarada entre dois blocos geopolíticos antagônicos: o ocidente capitalista, democrático e cristão e o oriente, comunista, totalitário e ateu (Summo y Pontieri, 2012:287).

Os textos produzidos pelas forças armadas brasileiras e argentinas caracterizam o tipo de conflito que se desenhava bem antes dos golpes bem como a possível atuação e intervenção das forças armadas. O acesso a esses manuais nos permitiu observar as relações interdiscursivas entre eles e entre os documentários-propaganda que analisamos.

Finalizamos assim este primeiro capítulo no qual apresentamos os documentários que formam nosso corpus, Brasil de Ontem, Hoje e Amanhã e Ganamos la Paz, bem como a noção de condições de produção, que mobilizamos ao descrevermos o modo como os regimes se instauraram em cada país, a sua relação com os meios de comunicação e a doutrina na qual se sustentavam, a de "Guerra Revolucionária".

No capítulo 2 descreveremos algumas categorias que utilizaremos para fazer a análise dos filmes, outros conceitos teóricos serão desenvolvidos no decorrer da análise, que realizaremos no capítulo 3 . 


\section{CAPÍTULO 2 - Alguns conceitos teóricos}

Neste capítulo apresentamos alguns conceitos teóricos que nos ajudaram a caracterizar o nosso objeto de estudo e a estabelecer com quais categorias de análise compatíveis com a noção de Condições de Produção, apresentadas no Capítulo 1, abordaremos os dois documentários-propaganda.

\section{0 gênero documentário}

Como nosso corpus está formado por documentários produzidos em estados nacionais diferentes e em línguas e momentos diferentes, nossa proposta é, assim como a de Fanjul, (2015:509), indagar "potencialidades descritivas e explicativas de categorias como "gênero de discurso" e outras para a abordagem comparativa"

Retomaremos o trabalho sobre os estudos linguísticos feito pelo filósofo Mikhail Bakhtin (1895-1975) para caracterizar a categoria de gêneros discursivos:

Las diversas esferas de la actividad humana están todas relacionadas con el uso de la lengua. Por eso está claro que el carácter y las formas de su uso son tan multiformes como las esferas de la actividad humana, lo cual, desde luego, en nada contradice a la unidad nacional de la lengua. El uso de la lengua se lleva a cabo en forma de enunciados (orales y escritos) concretos y singulares que pertenecen a los participantes de una u otra esfera de la praxis humana. Estos enunciados reflejan las condiciones específicas y el objeto de cada una de las esferas no sólo por su contenido (temático) y por su estilo verbal, o sea por la selección de los recursos léxicos, fraseológicos y gramaticales de la lengua, sino, ante todo, por su composición o estructuración. Los tres momentos mencionados -el contenido temático, el estilo y la composición- están vinculados indisolublemente en la totalidad del enunciado y se determinan, de un modo semejante, por la especificidad de una esfera dada de comunicación. Cada enunciado separado es, por supuesto, individual, pero cada esfera del uso de la lengua elabora sus tipos relativamente estables de enunciados, a los que denominamos géneros discursivos. (Bakhtin 1979, p. 248)

Dessa forma, consideraremos o documentário como um gênero discursivo que participa da esfera da informação pública. Alguns desses filmes 
participam também da esfera política, como os que estamos analisando. Outros, das práticas educacionais, às quais estes se assemelham como veremos no capítulo 3, na articulação de vozes.

Faremos uma caracterização deste gênero, sem pretender delimita-lo, mas sim descrever algumas de suas características tais como o conteúdo temático, o estilo verbal e sua construção composicional. Para isso recorremos a alguns conceitos teóricos propostos por Bill Nichols, autor que incursiona no gênero documentário na sua obra La Representación de la Realidad.

De acordo com Nichols, (1997:44) o documentário pode ser considerado uma prática institucional com um discurso próprio, ele tem o status de ser uma prova do mundo, pois sua preocupação fundamental é a representação do mundo histórico. Através de imagens vemos situações e acontecimentos que fazem parte de uma esfera de experiência compartilhada. Imagens do mundo que geralmente trazem questões sociais, culturais, problemas atuais e suas possíveis soluções. Segundo o autor a relação entre o documentário e o mundo histórico é a característica mais marcada do gênero:

El nexo entre el documental y el mundo histórico es el rasgo más característico de esta tradición. Utilizando las capacidades de la grabación de sonido y la filmación para reproducir el aspecto físico de las cosas, el filme documental contribuye a la formación de la memoria colectiva. Propone perspectivas sobre cuestiones, procesos y acontecimientos históricos e interpretaciones de los mismos. (Nichols, 1997:12)

O documentário mostra o aspecto físico de acontecimentos da história ou da contemporaneidade ao coloca-los em cena efetivamente trazendo imagens de fatos já acontecidos. Pensamos que esta característica está relacionada com aquilo que Bakhtin denomina "conteúdo temático", que corresponderia ao conjunto de temáticas possíveis de serem abordadas por um determinado gênero, como por exemplo, a histórica e a política.

Nos filmes a representação de uma realidade histórica específica é vista e mostrada através da câmera que é testemunha e que transforma o espectador em testemunha também. As imagens dessa realidade estão acompanhadas pela narração de uma voz em off cujo papel é protagônico na produção de sentidos. 
A materialidade verbal tem função central no documentário, a voz em off narra acontecimentos mostrando imagens e som que compõem a narrativa, embora a imagem seja fundamental, é a palavra que domina o documentário, é através dela que a imagem e o som ganham um sentido específico que é exibido como uma verdade. As imagens ilustram uma questão, mas são as palavras as que expõem ou "traduzem" seu significado. Nesse sentido observamos traços do que Bakhtin (1979) denomina "forma composicional", que neste caso é o modo como se realiza o sequenciamento das imagens e do discurso da voz em off.

Um dos recursos do documentário é o de provocar no espectador a tendência de colocar a atenção no que está sendo mostrado tirando o foco e a possibilidade de reflexionar sobre a forma como está sendo mostrado.

O documentário apresenta características de outros sistemas de não ficção que constituem o que Nichols chama de "discurso de sobriedade". A ciência, a economia, a política, educação, religião, são sistemas sobre os quais é pressuposto que têm poder instrumental e que podem alterar o mundo efetuando relações de ação e consequência.

Los discursos de sobriedad tienen un efecto moderador porque consideran su relación con lo real directa, inmediata, transparente. A través de ellos el poder se ejerce a sí mismo. A través de ellos se hace que ocurran cosas. Son vehículos de dominio y conciencia, poder y conocimiento, deseo y voluntad. (Nichols, $1997: 31$ )

O discurso de sobriedade convida o espectador a aceitar como verdadeiro aquilo que é narrado, gerando a expectativa de que lhe será apresentada a solução de um problema ou de um enigma. No discurso de sobriedade são incorporados vocabulário e entonação específicos, uma abordagem do mundo que é marcada pela austeridade, pelo tom comedido e assertivo, que procura passar a impressão de objetividade.

A seguir, vamos descrever as formas de organização, mais especificamente os modos de representação que costumamos encontrar nos documentários, pensando nesses modos como modelos não rígidos e alternantes. 


\subsection{Modalidades do documentário}

Para Nichols, (1997) as modalidades de representação são formas básicas de organizar textos em relação com certas características ou convenções recorrentes. Ele atribui ao documentário modalidades de representação como padrões organizativos em torno aos quais se estruturam a maioria dos textos e classifica as modalidades como: expositiva, de observação, interativa e reflexiva. Vamos fazer uma breve descrição dessas modalidades e observaremos o funcionamento de uma delas.

O documentário expositivo se caracteriza pela voz em off e as imagens que revelam o mundo histórico com objetividade, utiliza o som não sincrônico. Por sua vez, o documentário de observação, que surgiu com a facilidade de transporte dos equipamentos de gravação sincrônica, é uma modalidade que permite o registro sem a interferência do realizador, a câmera registra imagem e som, e o realizador não interfere diretamente. Com ainda mais mobilidade técnica, o documentário interativo surgiu da necessidade de deixar clara a perspectiva e a participação do realizador. Ele aparece, faz comentários e entrevistas diante das câmeras. Por último, o documentário reflexivo é aquele no qual se expõem as condições e a técnica e da linguagem cinematográfica.

Vamos nos deter especificamente na modalidade expositiva, porque como veremos, suas características estão presentes nos documentários que analisamos.

\subsubsection{A modalidade expositiva}

O documentário expositivo se dirige ao espectador diretamente, com intertítulos ou vozes que expõem uma argumentação a respeito do mundo histórico (Nichols,1997:65). Prevalece o som não sincrônico, o que quer dizer que tanto a voz em off quanto a trilha musical são acrescentados no estúdio de gravação posteriormente ao momento da realização das filmagens. A voz em off tem a possibilidade de fazer extrapolações a partir dos exemplos concretos oferecidos nas imagens, ela ordena e hierarquiza as informações, interpreta 
dando mais ou menos ênfase, seleciona aquilo que será reiterado na argumentação para construir sentido. Podemos dizer que nesta modalidade de representação, a imagem está a serviço do discurso verbal, a argumentação tem mais importância do que a continuidade espacial ou temporal que as imagens apresentam. Em muitos documentais nos deparamos com cortes de lugar e de tempo sem que isso nos cause estranheza, as imagens podem mostrar diversos lugares e espaços em desordem temporal, porque a lógica é estabelecida pelo discurso da voz em off. A materialidade verbal é o fio condutor deste tipo de filme.

Nesta modalidade encontramos muitas vezes trechos de entrevistas ou de discursos, mas estes também estão subordinados à argumentação oferecida pelo filme. A voz e a imagem de terceiros estão incluídas em uma lógica argumentativa cujo eixo está no discurso da voz em off. Essas outras vozes podem ser usadas como provas ou para justificar aquilo ao que se faz referência na voz em off, elas inclusive colaboram para reforçar a argumentação de outra pessoa. O autor ainda afirma que se essa tarefa de incluir outras vozes for bem sucedida, nós não observaremos como o realizador utiliza essas testemunhas ou entrevistados para comprovar algo, mas sim a efetividade da argumentação.

O discurso do documentário coloca em cena uma instância enunciativa à qual é atribuída a organização da sequencia que apresenta informação e o conhecimento que compartilhará com aqueles que desejam saber e que eventualmente também podem ocupar o lugar do sujeito que sabe o que quer dizer que esse sujeito que passa a saber pode se transformar em um divulgador daquele conhecimento que o filme lhe proporcionou.

.O discurso é predominantemente assertivo, ele estabelece questões de um modo enfático e sucinto, as imagens corroboram aquilo que a voz em off afirma. Este é um dos traços daquilo que Bakhtin denomina "estilo", que está relacionado aos recursos léxicos, freaseológicos e gramaticais. Se analisarmos esses recursos apenas dentro da língua, eles seriam percebidos como itens dentro de suas respectivas classes, mas ao analisarmos estes recursos dentro da totalidade do enunciado, observaremos um fenômeno de estilo, portanto para Bakhtin a escolha de determinadas formas gramaticais e lexicais é um ato estilístico. 
É o que observam também, ao analisar o uso das formas assertivas, outros autores como Ricardo, ao trazer a reflexão de Carroll:

Deste modo, ele identifica o documentário como sendo o domínio cujos enunciados são estruturados na forma de asserções, de proposições portadoras de um saber sobre o universo abordado no filme. Em outros termos, e do ponto de vista discursivo, trata-se de uma narrativa composta por asserções que mantêm uma relação de plausibilidade com a realidade que designam (CARROLL, 2005). Portanto, que julgamos confiáveis, credíveis. (Ricardo, 2014:12)

Nesse sentido, coincidimos com o autor ao entender que nos filmes da modalidade expositiva o uso de preceitos do discurso de sobriedade, a evidência das imagens e 0 uso de enunciados assertivos se tornam procedimentos centrais na construção de um vínculo de confiança com o espectador, gerando uma sensação de credibilidade.

Nichols (1997) também explora os supostos e expectativas que caracterizam a visualização de um documentário. Segundo ele a expectativa do espectador do documentário passa pelo compromisso intelectual e afetivo com um tema, uma questão ou problema, que está mediado pela retórica da objetividade (1997:59), característica do discurso de sobriedade. Outra expectativa do espectador de documentários é com relação à sua ânsia de conhecimento, ele se prepara para aprender algo sobre o mundo e desenvolve capacidades de compreensão e interpretação do processo que permitirá que ele entenda o documentário. $O$ espectador de documentários da modalidade expositiva costuma alimentar a expectativa de que diante dele se abrirá um mundo racional no que concerne ao estabelecimento de uma conexão lógica causa/efeito (1997:68), ele espera uma sequencia arranjada, verbalmente explicada e ilustrada pelas imagens.

A caracterização que até aqui fizemos do gênero documentário e da modalidade expositiva se aproxima das particularidades e recursos utilizados tanto no filme brasileiro Brasil, de ontem, hoje e amanhã quanto no argentino Ganamos la paz, no que diz respeito a seu conteúdo temático, que é a história dos acontecimentos políticos do Brasil e da Argentina durante as últimas ditaduras militares e no período imediatamente anterior, seu estilo que é assertivo, cheio de afirmações e sua construção composicional, que é 
caracterizada em ambos os casos pela voz em off que narra as imagens apresentadas.

Ao observar as características do documentário e dos chamados discursos de sobriedade caracterizados por Nichols, pensamos imediatamente em uma categoria de análise proposta por Maingueneau (2008), que é a categoria de discursos constituintes. É dela que nos ocuparemos a seguir.

\section{O Discurso Constituinte}

Ao tratar sobre que denomina discurso constituinte, Maingueneau (2008:37-38) afirma:

A pretensão desses discursos, assim chamados por nós de "constituintes", é de não reconhecer outra autoridade além da sua própria de não admitir quaisquer outros discursos acima deles [...] Eles operam a mesma função na produção simbólica de uma sociedade, uma função que poderíamos chamar de archeion. Esse termo grego, étimo do latino archivum, apresenta uma polissemia interessante para nossa perspectiva: ligado a archè , "fonte", "princípio", e a partir daí "comando", "poder", o archéion é a sede da autoridade, um palácio, por exemplo, um corpo de magistrados, mas também os arquivos públicos. $\mathrm{O}$ archéion associa assim intimamente o trabalho de fundação no e pelo discurso, a determinação de um lugar associado a um corpo de enunciadores consagrados, e à elaboração de uma memória. (MAINGUENEAU, (2008:37-38)

Para Maingueneau, o discurso religioso, o científico e o filosófico são discursos constituintes. Esses discursos são definidos assim porque utilizam uma fonte de autoridade: o discurso religioso fala em nome de Deus, ou o científico, em nome da ciência e da razão. Nesse tipo de discurso é como se existisse uma fonte legitimadora que é externa a eles, mas que na realidade é construída pelo próprio discurso.

Consideramos necessário esclarecer que situamos os documentários que analisamos como pertencendo ao discurso político. Considerando o político como propõe Guimarães (2005:16)

O político, ou a política, é para mim caracterizado pela contradição de uma normatividade que estabelece (desigualmente) uma divisão do real e a afirmação de pertencimento dos que não estão incluídos. Deste modo, o político é um conflito entre uma divisão normativa desigual do real e uma redivisão pela qual os desiguais afirmam seu pertencimento. 
Para Guimarães, o político é a contradição que coloca o conflito no centro do dizer, de modo tal que a desigualdade é apresentada como "necessária à vida social e a afirmação de pertencimento, e de igualdade, é significada como abuso, impropriedade" (2005:16). Nesse sentido, acreditamos que podemos situar os documentários Brasil de Ontem, Hoje e Amanhã e Ganamos la Paz dentro do discurso político, porque eles explicitam relações de disparidade e de conflito nas relações sociais a partir de um lugar institucional de poder.

Uma vez situados os filmes no campo político, retomamos o conceito de Maingueneau que localiza esse tipo de discurso "na confluência dos discursos constituintes, sobre os quais se apoia invocando a ciência, a religião, a filosofia" (2008:38). Os documentários que analisamos tentam validar sua pretensão de objetividade invocando diretamente a ciência, no caso do filme argentino, através da imagem e menção a destacados cientistas ganhadores do prêmio Nobel. No filme brasileiro podemos dizer que o discurso científico aparece através de gráficos e projeções de crescimento da indústria nacional e da infraestrutura, dados aos quais o espectador só poderia ter acesso através de textos institucionais de especialistas em economia, agropecuária, infraestrutura, etc. O discurso religioso também é assimilado em ambos filmes. No brasileiro, exaltando as riquezas potenciais do país, que é apresentado como ainda longe de ser um "paraíso desejado", mas com a perspectiva de concretização desse desejo. E no filme argentino com a invocação a Deus e à Pátria.

O locutor se coloca como estando fora da história que ele narra, mais precisamente ele se coloca "acima" dela, comprovando com as imagens uma verdade desde uma perspectiva superior e externa. Nesse sentido Maingueneau considera importante a questão da distancia: "distancia entre sujeito falante e posição de enunciação, distância entre intenções comunicativas e a significação do texto, distância entre instâncias de produção e de recepção" (2008:41).

Um dos aspectos do discurso constituinte observados por Maingueneau que queremos destacar é que "não reconhecem outra autoridade além de sua própria". Acreditamos que no discurso dos filmes objeto de nossa análise se 
apresenta a versão dos fatos históricos a partir de um lugar de autoridade, eles negam e excluem a possibilidade de outro discurso que reordene de forma diferente os acontecimentos históricos. Esse lugar de dizer de autoridade coloca na enunciação também os que estão impedidos de dizer. Eles são integrados ao quadro enunciativo, ora quando são caracterizados como o inimigo, e sua voz e trazida e personificada, ora quando a voz em off se dirige ao espectador interrogando-o diretamente. Coincidimos com a afirmação de Maingueneau (2008:40) "Cada discurso constituinte parece ao mesmo tempo como interior e exterior aos outros que ele atravessa e pelos quais é atravessado". Nesse sentido o uso de referências do mundo da ciência e a invocação a Deus atravessam o discurso que estamos analisando.

A versão apresentada nos filmes é posta como a Verdade, excluindo assim qualquer outro discurso sobre a história do país. Lembramos a função de archeion, mencionada por Maingueneau (2008:38) , como "fonte" ou "princípio", é dessa fonte "pura" que provém a voz do enunciador, trazendo assim a Verdade para os telespectadores. A Verdade provem de uma Fonte à qual o espectador não tem acesso direto, é por meio da interpretação da voz em off que o espectador pode compreendê-la.

Para Maingueneau, (2008:48), a análise dos discursos constituintes implica lidar com uma produção discursiva heterogênea, dado que ela abrange diversos gêneros. "Uma hierarquia se instaura entre os textos "primeiros" e os que neles se apoiam, para comentá-los, resumi-los, refuta-los". O autor utiliza um exemplo: ao lado dos textos da alta filosofia existem as apostilas escolares, ou as revistas de divulgação científica. Haveria assim um texto "primeiro" e um outro que o faz circular para além da comunidade de possíveis enunciadores desse discurso, chegando até as carteiras escolares, criando assim a partir do discurso da alta filosofia e apoiando-se nele, uma série de textos "segundos". O autor distingue:

[...] os textos ou gêneros primeiros (ou fontes) e os gêneros segundos, distinção que está na base das problemáticas de divulgação: de um lado, os discursos que supostamente produzem os conteúdos em sua "pureza"; de outro, os discursos que se limitam a resumir, explicitar, etc., uma doutrina anteriormente constituída (2008:48)

Sendo assim, cada discurso constituinte suscita gêneros segundos, que seriam "vulgarizados" para serem compreendidos, são discursos que: 
[...] é preciso comentá-los porque se supõe que a riqueza de seu sentido excede a capacidade dos intérpretes, porque há um déficit irredutível de toda interpretação em relação à "herméneia", à mensagem que, através desses textos a Fonte confia ao comum dos mortais. Em tal quadro hermenêutico, o texto não se reconheceria cometendo um erro, só há intérpretes deficientes". (2008:50)

Desta forma, utilizando essa técnica de "interpretação" do discurso não há possibilidade da existência de erro, se existisse tal possibilidade, estaria na falta de recursos ou de capacidade dos intérpretes, para quem a Verdade, é "traduzida". Por outro lado, podem-se dizer determinadas coisas, mas outras não; pode-se falar a partir de alguns lugares de locutor, mas não de outros, e portanto pode haver determinados interlocutores e não outros.

\title{
3. Cenografia e cena enunciativa
}

\author{
De acordo com Maingueneau (2008:51) nos textos "primeiros" de \\ discursos constituintes, aqueles que são a Fonte, o locutor deve dizer \\ construindo o quadro de seu dizer, ocupando assim um lugar que o autoriza a \\ dizer. Esse quadro de dizer é denominado pelo autor cenografia:
}

\begin{abstract}
A situação de enunciação não é, com efeito, um simples quadro empírico, ela se constrói como cenografia por meio da enunciação. Aqui -grafia é um processo de inscrição legitimante que traça um círculo: o discurso implica um enunciador e um co-enunciador, um lugar e um momento da enunciação que valida a própria instância que permite sua existência. Por esse ponto de vista, a cenografia está ao mesmo tempo na nascente e no desaguadouro da obra. (Maingueneau, 2008:51)
\end{abstract}

A cenografia não é para o autor uma simples cena, é preciso concebê-la ao mesmo tempo, como quadro e como processo, ela não é imposta pelo gênero discursivo, mas sim construída pelo próprio discurso. Na cenografia também é preciso considerar as vozes que pertencem ao "outro". Para autores como Fanjul (2016:12)

[...] a observação dessa cenografia impõe, para a abordagem analítica de textos de muitos gêneros do discurso, a consideração de uma diversidade de vozes e de entidades pessoais representadas que se acrescentam e que se entrecruzam com as múltiplas formas de presença do discurso "outro". Na nossa pesquisa, tem nos interessado a observação, em relação a lugares sociais de dizer, de todas essas instâncias: locutores, enunciadores de diferentes graus de 
especificidade e, ainda, personagens postos em cena, mesmo sem voz, por considerarmos que sua perspectiva pode relacionar-se ao dispositivo enunciativo.

Com o conceito de cenografia observaremos quais são as características do enunciador e do co-enunciador e o lugar e o momento em que a enunciação surge.

Ao pensarmos em como se dá a assunção da palavra das vozes e entidades representadas nos documentários que analisamos também mobilizaremos o conceito de cena enunciativa, mas com uma perspectiva diferente da proposta por Maingueneau. Consideraremos cena enunciativa como propõe Guimarães (2005:23). De acordo com o autor, a assunção da palavra se dá em cenas enunciativas. "Uma cena enunciativa se caracteriza por constituir modos específicos de acesso à palavra dadas as relações entre as figuras da enunciação e as formas linguísticas".

A cena enunciativa é o espaço no qual estão distribuídos os lugares de enunciação. Para Guimarães (2005):

Os lugares enunciativos são configurações específicas do agenciamento enunciativo para "aquele que fala" e "aquele para quem se fala". Na cena enunciativa "aquele que fala" e "aquele para quem se fala" não são pessoas mas uma configuração do agenciamento enunciativo. São lugares constituídos pelos dizeres e não pessoas donas de seu dizer. Assim estuda-la é necessariamente considerar o próprio modo de constituição destes lugares pelo funcionamento da língua. (Guimarães, 2005:23)

Como podemos observar a relação entre a língua e o falante se dá em espaços de enunciação, ou seja, espaços de funcionamento da língua nos quais os falantes são tomados por agenciamentos enunciativos que se configuram politicamente. As cenas são, para Guimarães (2005:23), "especificações locais nos espaços de enunciação" nas quais são distribuídos lugares de enunciação. Examinaremos a seguir, os lugares de dizer que o enunciador pode assumir na enunciação.

\subsection{0 enunciador}

Guimarães (2005) descreve várias possibilidades do lugar de dizer que o enunciador assume na enunciação. $O$ enunciador-individual retrata a 
individualidade independente da história, "é o lugar do eu que não sabe que fala em uma cena enunciativa" (2005:25). O enunciador-genérico diz aquilo que todos dizem, como um dito popular, ele se mostra como dizendo com todos os outros e também se apresenta como independente da história; o enunciador coletivo como ligado a um lugar [...]." corporativo, de um conjunto, que o dizer apresenta como um todo específico". (Guimarães, 2013:204); e o enunciadoruniversal que:

[...] se apresenta como não sendo social, como estando fora da história, ou melhor acima dela. Este lugar representa um lugar de enunciação como sendo o lugar do qual se diz sobre o mundo. $O$ enunciador universal é um lugar que significa o Locutor como submetido ao regime do verdadeiro e do falso. (Guimarães,2005:26)

$\mathrm{Na}$ cena enunciativa entram em jogo lugares de dizer, que junto com Guimarães chamamos de enunciadores, que se apresentam como independentes da história ou fora dela e representam a inexistência dos lugares sociais de locutor. Observaremos na análise dos filmes como o lugar de dizer não é fixo, ele pode se deslizar tomando uma perspectiva ou outra.

Podemos observar também como se dá a presença do outro no discurso, e para isso descreveremos a heterogeneidade discursiva.

\subsection{Heterogeneidade no discurso}

Nossa intenção é abordar aqui a heterogeneidade não relacionada à existência da enorme variedade de gêneros discursivos, mas também a heterogeneidade como característica constitutiva do discurso. Não podemos deixar de mencionar que para a formação de nosso corpus mobilizamos outros gêneros discursivos, como os Manuais de Guerra Revolucionária. No entanto agora, vamos no ocupar de descrever a heterogeneidade como conceito. 0 pressuposto da heterogeneidade é de que todo discurso é atravessado por outros discursos. "O outro" é utilizado em nosso discurso, seja na forma de representação do interlocutor ou ao retomar outros discursos anteriormente produzidos. Para a linguista Autier Revouz (1982) existem dois tipos de 
heterogeneidade: a constitutiva e a mostrada. A heterogeneidade mostrada é a presença explícita do discurso outro, detectável no fio do discurso. A autora afirma: "En el hilo del discurso que, real y materialmente, un locutor único produce, cierto número de formas, linguisticamente detectables en el nivel de la oración o del discurso, inscriben en su linearidad, el otro" (Autier Revouz [1982] 2011:7) . Para a autora a heterogeneidade mostrada, se caracteriza pela produção de formas detectáveis por um único locutor, como por exemplo, através de citações ou aspas, reproduzindo assim o discurso do outro manifestando explicitamente sua voz, como podemos observar:

Por este medio, su figura normal de usuario de las palabras es desdoblada, momentáneamente, en otra figura, la de observador de las palabras utilizadas; y el fragmento así designado- marcado por comillas, itálica, por una entonación y/o por alguna forma de comentario- recibe, con el resto del discurso, un estatuto otro. (Authier Revouz [1982] 2011:8)

Como nosso objeto de análise são audiovisuais, os recursos mobilizados para trazer a presença do outro se dão nesse suporte, a imagem e a voz do outro aparecem diretamente, o discurso do outro é trazido com a sua presença física, sua imagem e sua voz são recortadas e observadas através da voz em off que comenta e refuta seu discurso. Segundo a concepção de AuthierRevuz, as palavras não são exclusividade de um enunciador, elas já foram ditas em outro lugar e momento por outro enunciador e o seu sentido é modificado em função do lugar discursivo do enunciador e do momento da enunciação.

Por outro lado, a heterogeneidade constitutiva não se encontra marcada, não é detectável na superfície. O enunciador retoma outros dizeres anteriores, isso significa que não há discurso que não seja formado pela heterogeneidade constitutiva, ou seja, não existe discurso que não esteja perpassado por outros discursos.

No capítulo 3, no qual fazemos a análise de nosso corpus observaremos como se dá a presença do outro no discurso e como discursos outros são convocados no seu funcionamento. Também observaremos como se constroem as diversas cenas enunciativas, quais os lugares de dizer que 0 enunciador assume, qual o lugar do co-enunciador bem como o lugar social que o locutor ocupa no discurso. 


\section{CAPÍTULO 3 - Análise dos filmes}

Neste capítulo realizaremos a análise do corpus mobilizando as categorias que descrevemos nos capítulos anteriores, outros elementos teóricos serão apresentados no desenvolvimento da análise. É importante destacar que apresentamos a análise abordando, em um primeiro momento, o filme Ganamos la Paz e, em um segundo momento, o documentário Brasil de Ontem, hoje e Amanhã. No decorrer da análise do filme brasileiro nos referiremos a aspectos nos quais vemos contrastes possíveis com 0 documentário argentino.

\section{Ganamos la Paz}

\subsection{Dime cómo te llamas y no sabré quién eres}

O título do filme nos levou a uma série de questionamentos, em primeiro lugar, ao pensarmos nos diversos significados que o verbo "ganar" pode adquirir, vemos a possibilidade de construção de diversos sentidos. Usamos como referência a reflexão realizada por Pecheux ([1983] 2008:25) que, por uma feliz coincidência explora uma forma verbal muito próxima: os diversos usos e sentidos do verbo gagner (ganhar). "Com um sujeito animado (ou agente dotado de vontade, de sentimento, de intenção, etc)" o autor enumera várias possibilidades de associação do verbo "ganhar" com um complemento: "ganhar a vida, ganhar tanto por mês; ganhar em um jogo de azar, ser o vencedor do grande premio; ganhar terreno, espaço, tempo (sobre o adversário), ganhar um lugar, um posto; ganhar a simpatia de alguém..." Pêcheux( [1983] 2008:25)

No caso específico do título do filme Ganamos la paz, o complemento está presente "la paz". A paz se apresenta como um prêmio obtido depois que o exército argentino interveio e a tornou possível. Também podemos pensar em uma disputa, como uma batalha ou uma guerra, com o propósito da 
conquista de um território. Esse espaço é conquistado e essa disputa é vencida com a intervenção das forças armadas, é a partir desse acontecimento que se ganha a paz e que se produz uma distensão.

\subsubsection{Nós quem?}

Por outro lado, considerando a transparência e a opacidade no conteúdo sócio-histórico que o enunciado apresenta, surge uma questão que também é colocada por Pecheux: quem ganhou na verdade? A materialidade léxico sintática do enunciado Ganamos la Paz, coloca uma primeira pessoa do plural em função de sujeito e um complemento direto. No entanto a resposta à pergunta "quem ganhou" não é evidente nem transparente, porque esse verbo flexionado na primeira pessoa do plural no título não identifica a extensão do locutor, nem sua identidade imaginária, ele apresenta uma oscilação, uma opacidade que se percebe na indefinição do alcance imaginário dessa primeira pessoa do plural.

O uso do"nós" e de todas as marcas que representam a primeira pessoa do plural, como "nos, nosso" e a desinência verbal da primeira pessoa do plural, em espanhol argentino: "nosotros, nos, nuestro" possibilita a integração de outros enunciadores no enunciado. De acordo com Indursky (1992:65) "por seu intermédio, o locutor pode associar-se a referentes variados, sem especificá-los linguisticamente, daí decorrendo a ambiguidade de seu dizer". A autora considera o nós uma "não pessoa discursiva" porque designa conjuntos não nomeados lexicalmente, o "eu" associa-se assim a outros referentes não especificados para constituir o "nós" cujas fronteiras seriam indefinidas e móveis.

Desta forma, podemos pensar em algumas possibilidades que esse conjunto lexical não nomeado apresenta, poderia ser o regime, o estado ou a junta militar, como o conjunto de autoridades que detêm o poder. Também podemos pensar em "nós" associando essas autoridades à coletividade dos argentinos, porém não todos os argentinos, mas sim aqueles que estão alinhados ou que aceitam ou concordam com a perspectiva das forças do 
estado. Em ambas as hipóteses o "nós" refere-se ao espaço público institucional, sendo que no primeiro caso poderia ser apenas a voz do regime, do qual o enunciador seria seu porta-voz. No segundo caso, o "nós" teria maior abrangência, pois incluiria, além da voz do regime, alguns setores da coletividade argentina com os quais ele se unificaria, construindo assim um "nós" formado pelo regime e por esses setores da sociedade argentina.

Acreditamos que este "nós" mais abrangente que inclui parte do coletivo da sociedade é o que está presente em diferentes momentos ao longo do filme, nas poucas sequências onde se utilizam verbos na primeira pessoa do plural, como vemos a seguir:

(04:22) El sol está siempre allí y su luz ilumina todas las cosas y todos los actos. Hasta en las sombras más espesas llegan algunos de sus reflejos para aclararnos_la realidad, como en todas las verdades que veremos, imágenes auténticas, hechos reales captados por lentes inexorables".

(30:11) Ha llegado el momento de preguntarnos también: ¿Quiénes serán los destinatarios de esta victoria? Y al dar gracias al Señor por esos logros, exaltando imágenes de vida y de amor, podremos exclamar con énfasis: ¡Ganamos la paz!

Nas sequências que destacamos a seguir, o locutor utiliza os possessivos da primeira pessoa do plural, determinando um espaço e um coletivo que foi contaminado por uma ideologia exterior, alheia a esse sujeito:

(08:44) En la Argentina se vivía en paz, pero en el mundo se expande el cáncer de la violencia ideológica, contamina nuestra América y busca la Argentina como blanco del terrorismo internacional"

(09:31) Ese movimiento se infiltró en nuestra sociedad, sembró armas en América pacífica, engañó a jóvenes y a adultos"

Atentemos para o seguinte trecho no qual o uso do possessivo "nuestro" é mais abrangente ainda do que nos casos anteriores, já que se refere ao tempo que afeta a todos.

(29:42) La violencia recorre nuestro tiempo como una trágica manifestación del fanatismo irracional, de la agresión ideológica.

Já na sequência que segue, o possessivo "nuestra" aparece referido ao espaço da república onde se destaca a importância de um "hombre argentino", no qual também se incluem "extranjeros de buena voluntad" que colaboram com a construção do país para engrandece-lo. Acreditamos que nesta sequência, o "nuestra" é menos abrangente, pois incluiria a voz do regime e 
exclusivamente os argentinos e estrangeiros de "buena voluntad" que ajudaram a engrandecer a nação. Como podemos verificar:

(05:00) Un país donde el hombre argentino fundó sus obras, y donde llegaron extranjeros de buena voluntad para cultivar la tierra, levantar industrias, y contribuir al engrandecimiento de nuestra república."

$\mathrm{Na}$ sequência que apresentamos a seguir, aparece o pronome "nos" associado ao verbo dar e a Deus. É preciso ressaltar que, como mencionam Novaro e Palermo (2012:34) "el catolicismo fundamentalista y el anticomunismo habían sido, a lo largo de todo el siglo, los componentes más estables de la cultura militar y de sus alianzas político-sociales", a invocação de Deus aparece aqui como parte desse ideário. Mas, voltando à análise da sequência, temos a impressão de que o "nos" caracteriza o uso da primeira pessoa do plural mais abrangente de todos os exemplos que descrevemos anteriormente, pois, de acordo com a fé cristã que o pensamento castrense adota, Deus dá a vida a todos. No entanto, vemos nessa formulação que Deus dá a vida em nome da Pátria que oferece a todos os seres humanos a paz do trabalho e do lar. Deus e a Pátria estariam assim numa posição de igualdade. Nesse sentido, consideramos assim como Indursky (1992:73) que esse sujeito discursivo, em função de sua característica coletiva, socializa o seu dizer e o reparte com a não pessoa discursiva - a coletividade dos argentinos, como podemos verificar:

(30:20) Pues cayeron en nombre de Dios que nos da la vida, en nombre de la patria que nos brinda todo para vivir en la paz del trabajo y del hogar.

Observamos assim que nestas sequências o "nós" se torna um referencial discursivo difuso que estabelece a ambiguidade, posto que a mesma forma pode apresentar diversos referentes. 


\subsubsection{La guerra sucia}

Ainda analisando o título do filme e reflexionando sobre as formulações que prefiguram o golpe, encontramos uma referência em um discurso pronunciado pelo Comandante em Chefe do Exército, Jorge Rafael Videla, proferido na província de Tucumán, no dia 25 de dezembro de 1975:

Mientras la cristiandad festeja en familia la llegada del niño Dios, el Ejército Argentino en operaciones, aquí, en el corazón del monte tucumano como en todo el ámbito del país, lucha armas en mano para lograr la felicidad y esa paz que mi mensaje clama. ${ }^{16}$

O Comandante do exército argentino anuncia que o exército está lutando com armas na mão, e ele está clamando pela paz. Isso exclui a paz no período anterior à tomada do poder pelos militares, o que nos leva a questionar se o país estava em guerra. Nesse sentido adotamos a perspectiva de Feierstein $(2016){ }^{17}$ para quem as condições para uma guerra não estavam dadas, mas os seus atores usavam essa caracterização para justificar suas ações ilegais. De acordo com o autor, foram os próprios perpetradores que cunharam a expressão "guerra sucia", como podemos observar:

Por una parte, el término de "guerra" buscaba dar cuenta de una confrontación simétrica que igualaba a perpetradores y víctimas bajo una mirada binaria (en tanto contendientes de una batalla, lo cual en modo alguno da cuenta de lo que ocurrió, donde la enorme mayoría de los secuestrados fueron arrancados de sus casas, trabajos o de la vía pública por patotas clandestinas). El calificativo de "sucia" daba cuenta de la necesidad de legitimar acciones que en nada se vinculan con la guerra (dichos secuestros en condiciones de indefensión, el asesinato de los detenidos y secuestrados, la clandestinidad de las acciones, la desaparición de los cuerpos, la apropiación de los hijos de los secuestrados, la violencia sexual sistemática contra los detenidos, el sometimiento sistemático a la tortura, el robo y confiscación de sus bienes, entre otras acciones).

(Feierstein, 2016) (grifos do autor)

O conceito de guerra estava presente nas formulações produzidas pelos órgãos de segurança do estado, o conceito de paz emerge como a saída dessa guerra, e ele é usado também acompanhando o verbo ganar, em outro trecho do discurso do General Videla:

\footnotetext{
${ }^{16}$ Discurso de Videla: http://www.altillo.com/examenes/uba/cbc/semiologia/semio2007p1h.asp

${ }^{17}$ Guerra sucia: la importancia de las palabras

http://www.nuestrasvoces.com.ar/a-vos-te-creo/guerra-sucia-la-importancia-las-palabras/
} 
Frente a estas tinieblas la hora del despertar del pueblo argentino ha llegado. La paz no solo se ruega, la felicidad no solo se espera, sino que también se ganan.

Isso nos mostra que o título estabelece relações parafrásticas com enunciados que já circulavam no discurso dos militares antes mesmo de sua intervenção, prefigurando-se meses antes da tomada do poder.

A seguir nos ocuparemos de indagar como se caracteriza o inimigo no documentário argentino.

\section{20 inimigo subversivo}

O inimigo "subversivo" é caracterizado em vários dos manuais elaborados pelo ejército antes e durante o período do regime, como aponta Risler (2011:7):

La "subversión" se define como la "acción clandestina o abierta, insidiosa o violenta que busca la alteración o destrucción de los criterios morales y la forma de vida de un pueblo, con la finalidad de tomar el poder e imponer desde él una nueva forma basada en una escala de valores diferentes.

Ainda de acordo com a autora, os militares consideravam que o "objeto" dos "subversivos" era a mente do homem e a alteração de seus valores para "injetar" ideologias forâneas que alterassem a ordem da sociedade argentina, sua moral, valores e costumes ocidentais e cristãos. (Risler, 2011:9)

Os "subversivos" para o regime, não eram apenas aqueles que participavam de grupos armados de esquerda, mas também, sindicalistas, intelectuais críticos, estudantes, professores, operários e todo aquele que fosse ativista ou simpatizante de qualquer movimento de crítica social.

No documentário Ganamos la Paz, a definição do inimigo subversivo dada pelos militares é de caráter difuso. Por um lado, ele está personificado, como por exemplo, ao mostrar imagens e fragmentos de entrevistas dadas pelo Che Guevara e por Roberto Santucho, na época dirigente do Ejército Revolucionario del Pueblo. Por outro lado, como de acordo com o pensamento militar, o "inimigo subversivo" havia se infiltrado em toda a sociedade e estava 
presente em todos os setores da sociedade civil, ele é representado através de designações plurais, tais como: "elementos terroristas", "delinquentes terroristas", "bandas subversivas", "bandas terroristas", "bandas extremistas". Observamos assim o uso do termo "bandas", cujo valor semântico remete a um grupo cujas ações estão vinculadas à violência, como vemos no dicionário hospedado no site do grupo Clarín" significa: "Conjunto de personas relacionadas por algún rasgo en común”, "Grupo de personas seguidoras de un líder" "Cantidad numerosa de personas o de cosas". Ainda de acordo com o dicionário da RAE"19: "Grupo de gente armada" e "Pandilla juvenil con tendencia al comportamento agressivo". Do mesmo modo, a forma plural "elementos" também está vinculada à violência, não apenas por estar acompanhada de "terroristas", mas porque também pode se referir a algo negativo, posto que é um termo que circula e é utilizado no discurso policial.

Usando também a forma plural "sectores ciudadanos" surge aqui a menção àqueles setores da sociedade que festejaram o retorno de Perón à presidência da república e que foram usados pelos "marxistas enmascarados para retomar las sendas de la violencia”. Essa parcela da sociedade argentina, se bem não é o inimigo propriamente dito, ao ser apresentada como massa de manobra dos marxistas torna-se um inimigo potencial.

Observamos assim que a representação do inimigo tem um papel central em Ganamos la Paz. As superfícies discursivas que caracterizam os "elementos subversivos" e suas ações ocupam a maior parte do filme. Dos quase 30 minutos de duração, mais de 20 descrevem e mostram as ações dos "elementos terroristas" e de seus simpatizantes, é deles que se trata a maior parte do tempo. E são eles e suas ações os que fazem com que a "sociedade adoeça" colocando como imperativa a necessidade de intervenção da única instituição que permanecera imune, as forças armadas.

\footnotetext{
${ }^{18} \mathrm{http}: / / \mathrm{www} . c l a r i n . c o m / d i c c i o n a r i o$

${ }^{19} \mathrm{http} / /$ dle.rae.es/
} 


\subsubsection{Um país contaminado}

Esse inimigo difuso é o que contamina o país com o "câncer da violência ideológica" e que deixa a sociedade doente. A ideia da sociedade enferma é reforçada pelo uso de sequências onde surgem referências ao corpo humano, associadas à morte e à violência, como podemos observar:

(10:27) En todas partes hay puños en alto, golpes, sangre, heridos, muertos hay rostros iracundos y puños.

(11:15) Muertos, heridos, sangre. La prédica disolvente llega a la Argentina también, siglas extrañas ensucian los muros, perturban las aulas y hay rostros iracundos y puños. Así fue como estallaron disturbios en la Argentina con graves daños y muchas víctimas inocentes. Así fue como la calma cedió paso a las expresiones del odio, al golpe artero y a la sangre.

(12:25) siempre el fuego, la pedrada, la bomba, las barricadas del odio y las víctimas sangrantes.

(13:52) Quedan restos, esqueletos de vehículos incendiados, señales inequívocas en fin del terrorismo.

(14:25) La sociedad argentina se conmovió al comprobar cómo se extendía el cáncer. Un cáncer implacable que provoca muerte.

(14:42) En un oscuro pueblito provinciano fueron descubiertos los restos lacerados del ex mandatario asesinado. La sociedad argentina se conmovió al comprobar cómo se extendía el cáncer. Un cáncer implacable que provoca muerte.

(15:26) Y sigue la serie sangrienta, otro líder sindical de destacada actuación es abatido cobardemente, víctima también de la violencia.

(18:31) Otra vez las llamas destruyendo y los puños en alto, los gritos de odio, las piedras agresivas.

(19:15) Y mientras las fuerzas del orden procuran evitar daños mayores, la Plaza de Mayo, recinto de los acontecimientos históricos argentinos, es invadida ese 25 de mayo de 1973, por carteles marxistas y puños en alto.

(24:32) Caen civiles, militares, sacerdotes. Quieren imponer el terror, paralizar el cuerpo social de la República. 
Observamos que essas enumerações formam sequências junto a representações da violência e aparecem sempre associadas à destruição, à morte, ao ódio, ao terror e a paralise. As enumerações de partes do corpo estão acompanhadas de imagens de tumultos nas ruas, manifestações violentas, atentados, ambulâncias, carros sendo incendiados, pessoas armadas, feridos e mortos. A violência é fortemente representada no filme e atribuída apenas ao inimigo, o uso das expressões que designam partes do corpo reforça a imagem de um país cujo cuerpo social foi tomado por partes, assim como o câncer ataca o corpo humano, a pretensão do inimigo seria contaminar o corpo social por completo.

O uso de enumerações do corpo humano, denominado "metáfora organicista" é observado por O'Donell (1998), como sendo recorrente no discurso da extrema direita, como observamos:

A perversa combinação entre o que aconteceu antes de março de 1976
e a furiosa paranoia dos então ganhadores, conduziu ao diagnóstico de
que era o "corpo social" inteiro, ainda nos seus "tecidos" mais
microscópicos, quem tinha sido "infeccionado" pela subversão
(desconfio que poucas vezes na história a extrema direita martelou
tanto nas suas metáforas, tipicamente organicistas, como o fez durante
esses anos). O "caos", a "subversão" e a "dissolução da autoridade"
não haviam ocorrido apenas nos grandes cenários da política nem
estavam expressos somente nas ações das organizações guerrilheiras:
a doença existia também, e desde ali alimentara aqueles "sintomas"
mais visíveis, em quase qualquer canto da sociedade. O'Donell (1998)

As cenas de violência são colocadas no período que antecede ao golpe e são atribuídas ao inimigo, dando a impressão de que é a "subversão" a única responsável pela violência e pelos males que afligem o país. No entanto, como descrevemos no capítulo 1, a violência imposta pelo regime militar através do terrorismo de estado foi muito mais abrangente, intensa e estruturada do que aquela praticada pela guerrilha. O modus operandi do regime, assim como 0 dos grupos para-policiais, é mostrado como proveniente do inimigo subversivo. É como se houvesse uma inversão de papéis na forma como são narrados os acontecimentos, é o outro, o subversivo, o terrorista, o delinquente a causa dos males que afligem a nação. 
Também nesta sequência, observamos essa inversão de papéis. 0 locutor menciona que naquele período os direitos humanos eram desconhecidos. Acreditamos que o uso dessa expressão é uma resposta dialógica aos discursos que circulavam no exterior sobre as violações aos direitos humanos que estavam acontecendo naquele período. Uma resposta àquilo que o regime militar argentino chamou de "campanha antiargentina", que fez parte da estratégia publicitária do Proceso, principalmente antes e durante o Campeonato Mundial de Futebol (1978) realizado no país. Dessa campanha o slogan mais conhecido foi "Los argentinos somos derechos y humanos", elaborado como resposta às denúncias feitas no exterior por sobreviventes dos centros clandestinos de detenção, que foram divulgadas por vários meios de comunicação fora do país.

(11:04) Los derechos humanos son desconocidos por quienes propenden al caos y lo más sagrado, la vida misma, es arrasada en aras de esas ideologías.

As construções utilizadas para se referir aos anos anteriores ao golpe e principalmente aos modos de funcionamento das "bandas subversivas" mostram um inimigo organizado que realiza ações como: enganar, assassinar, burlar, usar, ensinar a matar. Como podemos verificar:

(09:31) Ese movimiento se infiltró en nuestra sociedad, sembró armas en América pacífica, engañó a jóvenes y a adultos. Enseñó a matar. Así se asesinó, se copó aviones civiles y con frases hechas y arteros procederes confundieron las mentes.

(09:53) Lo hicieron quienes en Chile procuraron llegar por atajos siniestros a la conquista del poder, los que enarbolaron sus rojos pendones, los que burlaron a la democracia y la usaron solapadamente para entregar los pueblos al marxismo internacional, los personeros de esa ideología hablan y generan la violencia y la muerte.

(10:39) La marea siniestra llegó a oriente y también se enseñoreó allá la violencia irracional

O inimigo subversivo, causador da violência que assola o país, é sempre nomeado através do uso de formas plurais, dando a impressão de se tratar de um ser difuso, anônimo, capaz de atuar em vários setores da sociedade. Seu modo de ação e os métodos para implantar o caos são: "predicar ódio, matar 
vítimas inocentes, causar danos, perturbar a ordem". As "bandas subversivas" utilizam métodos e ferramentas destrutivas: "pedras, bombas, incêndios".

(10:48) En todas partes la paz es perturbada, las autoridades legítimas son desafiadas por los que predican el odio, la destrucción, las soluciones prepotentes.

(11:34) Así fue como estallaron disturbios en la Argentina con graves daños y muchas víctimas inocentes

(12:20) los terroristas ensayan allí sus métodos destructivos, siempre el fuego, la pedrada, la bomba, las barricadas del odio y las víctimas sangrantes.

(15:42) Esa violencia parecía no tener fin: bombas, atentados de todo tipo, incendios intencionales. Son destruidos comercios para provocar pánico, tratar de imponer el terror y crear desabastecimiento. En definitiva, se busca el caos social, clima ideal para la subversión.

(19:33) Entretanto, los cómplices de la subversión encaramados en el gobierno, a la sombra de un equívoco concepto de la libertad, abren las puertas de las cárceles a los delincuentes.

Ainda de acordo com o filme, a sociedade começa a sofrer as consequências da contaminação ideológica, não há mais segurança e qualquer cidadão pode ser vítima do terrorismo, reforçando assim a ameaça de que era preciso erradicar o terrorismo que amedrontava os argentinos:

(14:55) Más horror, la ciudadanía argentina repudia esa crueldad.

(21:23) Estalla la violencia. Hay tiros, gritos iracundos, hay víctimas y por sobre el ulular de las sirenas se oye el gemido de los heridos. seguro

(23:40) El estupor se generaliza entre el pueblo. Nadie se siente

(24:23) Acentúa la subversión marxista su accionar. Hay más masacres. El terrorismo indiscriminado cobra otras víctimas.

A música faz parte da estrutura composicional, ela dá o tom dramático, sons graves e violinos acompanham e intensificam os momentos trágicos e violentos. $E$ nos primeiros minutos do filme, nos quais é mostrada a Argentina como um país próspero, cheio de riquezas, a música é suave, alegre e otimista. Podemos pensar que em alguns momentos há som sincrônico, pois podem se ouvir vozes de tumultos, gritos, sirenes, tiros e barulho de chamas ardendo. No entanto, temos a impressão de que se trata de sons que podem ter sido 
gravados sincronicamente em locais onde aconteceram conflitos, mas que parecem ter sido editados posteriormente, já que eles se repetem da mesma forma em vários momentos do filme.

Na próxima seção, veremos como se caracteriza a interlocução no filme Ganamos la Paz e quais as características do locutor

\subsection{A interlocução representada}

Um dos objetivos que nos propomos é analisar a interlocução representada e o lugar dado as entidades coletivas em relação a essa interlocução, pensando no conceito de cena enunciativa (Guimarães, 2005:23) descrito no capítulo 2, considerando assim os "modos específicos de acesso à palavra dadas as relações entre as figuras da enunciação e as formas linguísticas".

É importante retomar que classificamos os filmes como pertencentes ao "gênero documentário", do tipo propaganda, que está submetido às características deste gênero: ele se constitui como um discurso institucional, com características próprias. Ele se coloca como uma prova do mundo e tem como preocupação fundamental a representação do mundo histórico. (Nichols, 1997). Um discurso que se coloca como a narrativa da verdade que é comprovada e autenticada pelas imagens. Nesse sentido, pensamos na figura do enunciador-universal, aquele que fala uma verdade, a partir do que se apresenta como evidência, e que se coloca como estando acima da história, lembrando que esse enunciador-universal funcionaria como um intérprete da Verdade, que é a Fonte que ele representa.

Embora não esteja presente em nenhum dos dois filmes a voz de uma autoridade oficial, ao se tratar de uma prática institucional com um discurso próprio, que se coloca como prova do mundo e cuja preocupação fundamental é a representação do mundo histórico, essa voz assume um lugar de autoridade, de detentora de um saber que compartilha no filme. O espaço que ocupa é um espaço institucional no qual o locutor se coloca em um lugar de saber e a partir desse lugar de saber, assume uma autoridade que expõe e 
compartilha com o interlocutor. Esse discurso institucional como vimos no capítulo 2, denominado por Nichols (1997) discurso de sobriedade, se apresenta como um sistema que tem poder instrumental e que pode alterar 0 mundo efetuando relações de ação e consequência.

Los discursos de sobriedad tienen un efecto moderador porque consideran su relación con lo real directa, inmediata, transparente. A través de ellos el poder se ejerce a sí mismo. A través de ellos se hace que ocurran cosas. Son vehículos de dominio y conciencia, poder y conocimiento, deseo y voluntad. (Nichols, $1997: 31$ )

No discurso de sobriedade são utilizados vocabulário e entonação específicos, o tom é austero e assertivo, passando a impressão de objetividade. Nosso questionamento agora é qual o lugar que ocupa quem assume a palavra nesse tipo de discurso? Nesse sentido, adotamos a perspectiva de Guimarães (2005:23) para quem "assumir a palavra é pôr-se no lugar que enuncia, o lugar do Locutor (com maiúscula)". Para o autor, o Locutor "é então o lugar que se representa no próprio dizer como fonte deste dizer" (idem), mas ele só pode ocupar este lugar afetado pelos lugares sociais autorizados a falar. De acordo com Guimarães (2005) :

[...] para o Locutor se representar como origem do que se enuncia, é preciso que ele não seja ele próprio, mas um lugar social de locutor (...) em outras palavras, o Locutor só pode falar enquanto predicado por um lugar social. A este lugar social do locutor chamaremos de locutor-x, onde o locutor (com minúscula) sempre vem predicado por um lugar social que a variável $\mathrm{x}$ representa (presidente, governador etc.). (GUIMARÃES, 2005: 24).

\subsubsection{A cena enunciativa e o locutor}

Na cena enunciativa, o locutor assume um papel preponderantemente disciplinador, por isso o denominamos locutor-disciplinador. Como vimos, o Proceso de Reorganización Nacional tinha como propostas, por um lado, estabelecer uma nova ordem social, e por outro, disciplinar a sociedade, utilizando não apenas o terrorismo de estado, mas também outras formas de controle social como a Ação Psicológica, que buscou afetar o comportamento da sociedade. O caráter disciplinador do autodenominado Proceso de 
Reorganización Nacional, é observado por O' Donnell (1984), para quem o regime militar tentou:

[...] ordenar serialmente una sociedad que hasta ese momento estaba "desubicada": los de arriba, arriba y mandando, los de abajo, abajo y obedeciendo - y en todo caso, agradeciendo las paternales preocupaciones que los de arriba les dispensarán cuando las cosas se hayan "enderezado"; y los del medio, viviendo su eterna esquizofrenia: mandando y obedeciendo, pero sabiendo claramente a quién mandar y a quién obedecer. O’ Donnell (1984:31)

Os autores Novaro e Palermo (2012) também mencionam um texto de O'Donell onde é descrita a necessidade de disciplinar a sociedade:

Mientras tanto, cada uno debería dedicarse a lo suyo (O’Donell 1984): las mujeres a ser buenas amas de casa, esposas y madres; los maestros, a su función apostólica de formar argentinos de bien y respetuosos del orden; los estudiantes a estudiar; los jóvenes, a aprender a obedecer y respetar a sus padres; los obreros, a trabajar con regularidad; los empresarios, a producir. (Novarro e Palermo, 2012:33)

\subsubsection{Os salvadores da pátria}

É preciso lembrar que as forças armadas se consideravam a única instituição que estava a salvo do câncer da ideologia, a única que não estava "doente" e que não tinha sido "contaminada pela subversão" e que, portanto sabia qual era o rumo que o país devia tomar. Como lemos em Lvovich e Bisquert (2008).

A través de este diagnóstico las fuerzas armadas se ubicaron en el lugar de salvadoras de una nación en permanente caos, producido por el desgobierno, la corrupción de sus gobernantes, la primacía de los conflictos e intereses sectoriales y, especialmente, por el flagelo de la subversión. El golpe del 24 de marzo fue presentado y justificado como un intervención destinada a salvar a Argentina de una situación de caos y desorden". Lvovich e Bisquert (2008:16).

Ao colocar as forças armadas como salvadoras da pátria, o locutordisciplinador constrói no filme uma perspectiva na qual a lógica imperante é bilateral: ou amigo ou inimigo, ou se aceitava a ordem imposta pelo regime ou 
se voltava ao "caos" que imperava antes do golpe, não existia uma outra alternativa.

O locutor expõe uma "realidade irrefutável" que ele observa e mostra, e colocando essa verdade de forma tal que não há possibilidade de questionamento ou dúvida sobre ela. Por outro lado, na primeira sequência do filme na qual se usa o tom proverbial, irrompe o que Guimarães (2005) denomina como "enunciador-genérico":

El sol está siempre allí y su luz ilumina todas las cosas y todos los actos. Hasta en las sombras más espesas llegan algunos de sus reflejos para aclararnos la realidad, como en todas las verdades que veremos, imágenes auténticas, hechos reales captados por lentes inexorables.

As imagens e a narrativa do caos e da violência presente antes do golpe de 1976, mostradas como provenientes das "bandas subversivas" servem não apenas para contrastar aquele período com o pós golpe, mas também funcionam como uma advertência velada daquilo que pode acontecer com aqueles cidadãos que estariam "desubicados" com relação ao seu papel na sociedade.

. O inimigo é caracterizado através das vozes e imagens de terceiros, a presença desses discursos outros está no fragmento da entrevista com o Che Guevara. Esse trecho é utilizado para representar a origem do mal que "contamina a América". Observamos nesse fragmento a heterogeneidade discursiva mostrada, a presença do outro de forma explícita, sua imagem e sua voz de forma marcada, são as palavras do outro, ditas por ele, as utilizadas para compor o discurso do mesmo. A presença da entrevista com o Che nos mostra também como os gêneros discursivos se utilizam de outras vozes através de outros gêneros que incorporam. Neste caso, a voz do outro, é utilizada para colocar a perspectiva de um conflito com a ideologia que representa a origem do "câncer da violência que contamina o país". A voz do Che Guevara que irrompe no fio condutor do discurso do locutor-disciplinador marca também a diferença entre o "hombre argentino" e o subversivo e contribui para a delimitação do lugar de dizer desse locutor. Sua voz é trazida para marcar a posição de um lado, do locutor-disciplinador e do outro, do portador da doença da qual é preciso salvar o país. . 
O "hombre argentino", o cidadão modelo que gosta de viver a vida no cenário mostrado, esse homem que "trabalha, produz riquezas para o país, mantém as tradições dos gaúchos dos pampas e se compara aos homens de destaque da história do país, como os vencedores do prêmio Nobel", é o homem para quem a paz é ganhada, são "los millones de argentinos que buscan una causa fundada en el amor, en la justicia y en la libertad "Nesse sentido, acreditamos que o locutor se dirige àqueles que estavam de acordo com o proceder do regime, teórica ou realmente.

O caráter disciplinador é uma das características mais fortes que pensamos estar presente em Ganamos la Paz. Ele se manifesta não apenas na figura do locutor-disciplinador, mas também na instalação da figura do enunciador-universal, aquele que está acima da história, aquele que diz sobre o mundo que "traduz" a Verdade. A constante representação da violência nas imagens contribui também para construir esse caráter disciplinador.

Outro aspecto importante a destacar, que descrevemos anteriormente, é que os "elementos subversivos" têm um papel central na enunciação. Sua presença na enunciação é mostrada como caótica e causadora da "contaminação do câncer da violência".

Passaremos agora a analisar aspectos que consideramos importantes do documentário brasileiro Brasil de Hoje, Ontem e Amanhã. Na nossa análise realizaremos algumas observações comparativas entre os dois filmes.

\section{Brasil de ontem hoje e amanhã}

\subsection{0 título}

O título do documentário brasileiro se apresenta como um todo espaçotemporal, "Brasil de Ontem, Hoje e Amanhã", uma linha de tempo que abrange o passado, o presente e o futuro. O lugar onde se instala a enunciação é o Brasil, que é por um lado apresentada a partir do Brasil, que é também objeto do discurso. Por outro lado, se bem os advérbios hoje ontem e amanhã abrangem todos os tempos, ao não haver um parâmetro temporal específico, como por exemplo, uma data marcada, nessa formulação não há indícios do 
"hoje" nem sabemos até onde chegam o passado e o futuro. Mas ao pensarmos nas condições nas quais o documentário circulou, que é o programa de televisão Amaral Netto, o Repórter, esse tempo é localizável. O "hoje" usado na televisão, principalmente na informação televisiva remite àquilo que se apresenta como "atualidade", que pode ser notícia e que deve ser informado por esses meios socialmente autorizados a informar. Paralelamente, se pensamos no título do filme fora do contexto da sua "atualidade", não conseguimos localizar pelo título os tempos aos quais ele se refere. Como veremos, o locutor apresenta esses três momentos como sendo: o passado (Brasil de ontem) marcado pelo caos social, o descontrole inflacionário, e o presente e o futuro (Brasil de hoje e amanhã) que corresponderiam à superação da crise e à retomada do crescimento.

A representação de um todo também aparece na primeira imagem do filme, que é do mapa Brasil, um mapa sobre um céu estrelado, sem países limítrofes, sem oceanos nem continente. $O$ fundo do mapa é o céu estrelado que mostra $\circ$ Brasil fora de contexto, flutuando no universo. A seguir é apresentado o mapa da América do Sul no qual o Brasil surge recortado e separado do continente (Figura 1), como se houvesse entre a América e o Brasil uma fronteira natural, que não se distingue se é o mar ou espaço vazio que apenas separa.

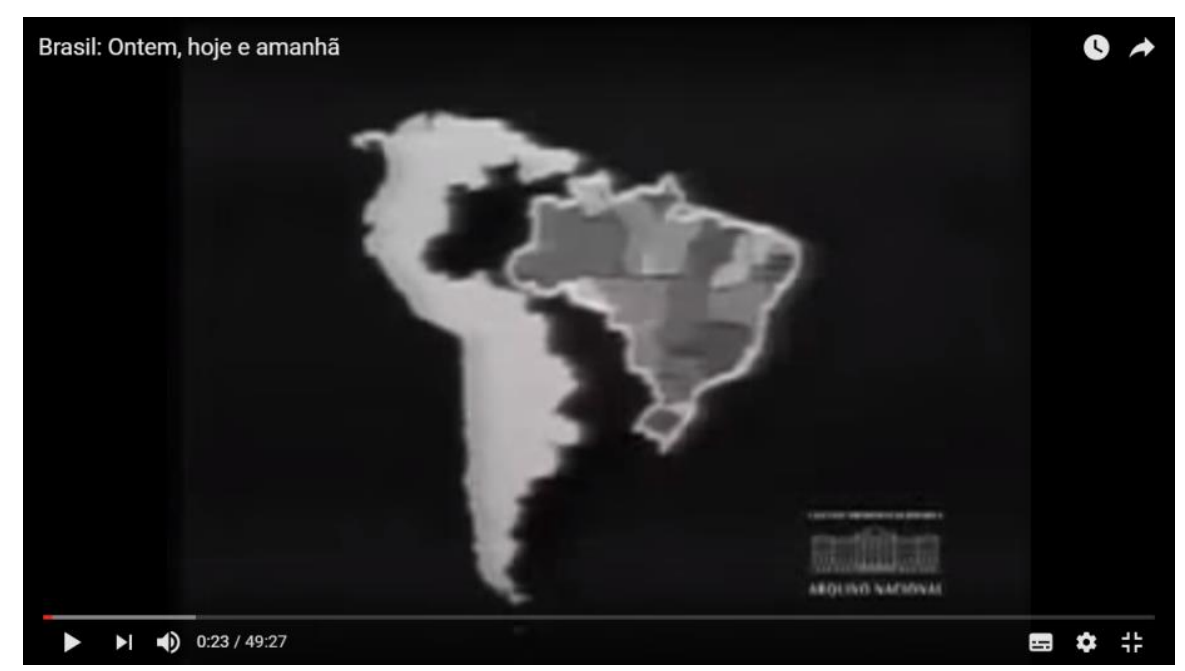

Figura 1: mapa do Brasil recortado, imagem retirada do filme "Brasil de Ontem, Hoje e Amanhã" 


\subsection{A ilha Brasil e o Brasil Grande}

O Brasil se apresenta como uma ilha. A construção imaginária do Brasil como ilha é abordada por vários autores. De acordo com Oliveira (2008:54) há entre os elementos imaginativos de "invenção do Brasil", o mito da Ilha-Brasil que, "se encontra fundamentado em concepções teóricas advindas da doutrina das fronteiras naturais".

Embora saibamos que as fronteiras são, em essência, políticas e, portanto, artificiais, não sendo nunca naturais, a concepção da doutrina das fronteiras naturais foi um elemento importante para construção da ideologia geográfica que viria a fundamentar a criação da identidade nacional brasileira. (Oliveira, 2008:55)

De acordo com Oliveira, a doutrina das fronteiras naturais surgiu na França no século XVIII, na área do Direito e da Geografia e baseia-se na noção de que as nações estavam predestinadas a ocupar determinado território, que estaria delimitado por fronteiras naturais. Para o autor essa doutrina:

[...] funcionou como elemento organizador da narrativa de construção do território nacional brasileiro. Essa narrativa foi obra coletiva da elite imperial a partir de um olhar romântico dirigido para o passado colonial. A intelectualidade do Império entregou-se à fabricação de uma tradição nacional, cortando e montando peças de um quebra-cabeça da pátria imaginária. (2008:56)

Dentro dessa doutrina, a Ilha-Brasil seria uma concepção imaginária de uma unidade natural que se erguia como realidade territorial e que teria sido dada como herança aos portugueses, o que pressupõe que essa unidade territorial existia antes mesmo da colonização. De acordo com o autor o "mito" da ilha e o das fronteiras naturais fundiram-se na narrativa das elites do Império do Brasil e se tornaram um "elemento definidor da identidade nacional brasileira". (Oliveira, 2008:57). Nesse sentido o Brasil seria visto como um espaço e não como uma comunidade de indivíduos.

Essas ideologias geográficas vão ser geradoras de discursos legitimadores de uma identidade nacional onde o Brasil é visto como um espaço a ser conquistado e ocupado. Em sendo assim, o povo é visto como mero instrumento de construção do país, subalternos às ideias e projetos das elites. (2008:58)

O papel do povo, de acordo com essa ideologia, é visto como um instrumento de realização do projeto das elites, portanto ele está excluído como 
participante ativo da construção desse projeto, está lá para executa-lo, sem ter participação na sua criação e certamente sem compartilhar de seus benefícios.

Nesse sentido, Oliveira ainda nos dá uma perspectiva temporal dessa visão do povo:

Somente em meados do século XX, a ideia de povo começa a ganhar alguma ressonância e significado na discussão da identidade nacional no Brasil. Contudo,com o golpe militar em 1964, o autoritarismo espacialista retoma o controle sobre a imaginação e construção da identidade nacional, reforçando uma visão geopolítica de atuação governamental e identificando o Brasil ao seu território. (2008:59)

Vemos que essa ideologia da fronteira natural está representada no filme Brasil de Ontem, Hoje e Amanhã, e como esse autoritarismo espacialista está presente no filme através da imagem da ilha, isolada do contexto continental, ocupando um imenso território.

O Brasil é o protagonista do filme, e esse Brasil é fundamentalmente um espaço, não uma comunidade. Para mostrar a dimensão e a grandeza do Brasil são apresentadas sobre o mapa as distâncias entre os extremos norte e sul e leste e oeste do país. Ao fazer uma comparação, em vez de colocar o Brasil no cenário mundial, em um mapa-múndi, por exemplo, e assim comparar suas dimensões com relação a outros países, é utilizado um recurso que chamamos de "contexto invertido". O Brasil é mostrado como o todo no qual poderia caber: "toda a Europa, menos a União Soviética, a América Central, o Japão, Tailândia, Israel e ainda sobraria espaço". As imagens mostram o mapa de cada um desses países dentro do mapa do Brasil. O Brasil é praticamente representado como um continente e se transforma na medida parâmetro, sem contextualização, nem vizinhos. Sua relação com o resto do mundo é apresentada não como o Brasil no mundo, mas como o mundo no Brasil. 


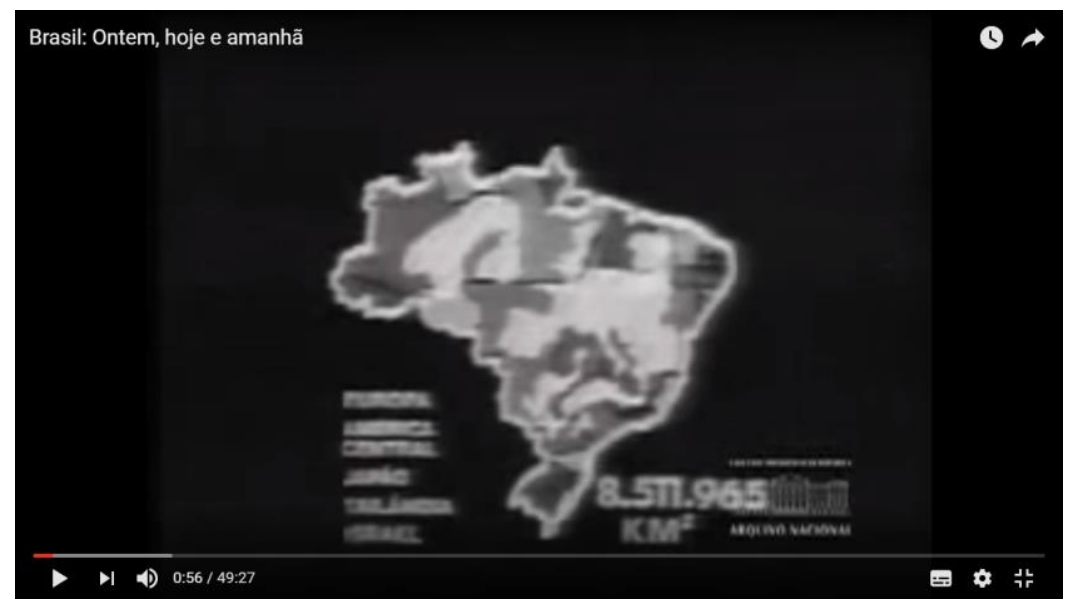

Figura 2: países do mundo representados dentro do mapa do Brasil, imagem retirada do filme "Brasil de Ontem, Hoje e Amanhã"

A grandeza do Brasil é destacada não apenas nas imagens, mas também em várias formulações, tais como: "Brasil, um país continente", "Um gigantesco país", "Foi este Brasil de dimensões continentais". De acordo com Chirio (2012:168) a ideia do Brasil grande e do Brasil potência era central no imaginário militar e seus "símbolos são as grandes obras de infraestrutura: a abertura da rodovia Transamazônica e a construção da usina hidrelétrica de Itaipu marcaram, assim, fortemente as memórias militares". Essas obras são mencionadas no filme como uma das "grandes realizações" dos governos militares e são apresentadas no "Brasil de Hoje e Amanha".

\subsubsection{O gigante de joelhos}

Outro aspecto que queremos destacar é que a ideia de doença e de enfermidade também aparece no documentário brasileiro, no entanto de forma diferente que no filme argentino, onde o "câncer ideológico contamina a Argentina" e se "infiltra na sociedade enganando jovens e adultos". Em Brasil de Ontem, Hoje e Amanha, a visão do Brasil enfermo surge a partir de uma perspectiva posta como externa, de como o país era percebido por outros países, como podemos observar nestas sequências:

(03:56) O Brasil é um país enfermo, dizia-se lá fora, será uma nova Indochina, o gigante está de joelhos, essa é a opinião corrente, fazendo ainda mais triste a nossa imagem pelo mundo afora. Pois o 
que se dizia no exterior apenas retratava nossa real situação, sem saber como seria o dia de amanhã.

(29:29) Há 11 anos passados havia também manchetes, mas, você se lembra? Elas falavam não de um Brasil que realiza, mas de um Brasil enfermo, doente, falavam do gigante de joelhos.

(32:32) Pois o que se dizia no exterior apenas retratava nossa real situação, sem saber como seria o dia de amanhã deixou no passado há apenas 11 anos sua condição de país ilhado em mutismo, cego, surdo, mudo.

No entanto, não sabemos como o Brasil "adoeceu", mas podemos pensar que os primeiros "sintomas" são mostrados nas seguintes sequências formuladas quando se faz a descrição do passado, do "Brasil de ontem":

(02:21) E o Brasil sofria uma de suas piores crises: greves sobre greves, ameaça de guerra civil, caos quase incontrolável, deterioração econômica e financeira, indisciplina invadindo os quartéis, inflação galopante, forçando para o alto praticamente cada semana os preços de tudo.

(04:46) Ultimatos ao congresso, agitações de rua, insegurança, ameaças aos jornais, agravamento da crise econômica e financeira.

É importante lembrar que os militares brasileiros haviam adotado a doutrina da "guerra revolucionária", que expusemos no Capítulo 1, e que de acordo com ela, uma das táticas utilizadas pelo inimigo era, assim como acreditavam os militares argentinos, a conquista física e moral da população. De acordo com essa visão e conforme vemos em Chirio (2012), os inimigos:

[...] empregam, de um lado, "técnicas destrutivas" - entre as quais, greves, "terrorismo", "manejo das massas (comícios e desfiles monstro)", guerrilha - e "construtivas" - propaganda, formação de ativistas, enquadramento das massas graças ao estabelecimento de "hierarquias paralelas", construção de um aparelho governamental clandestino. (Chirio,2012:21)

Acreditamos que a mobilização popular, as greves e os protestos são percebidos pelo regime como parte da estratégia do inimigo de corromper a sociedade.

A trilha sonora colabora para reforçar os "momentos dramáticos". A composição musical acentua o clima de tensão. Assim como no filme argentino, nesses momentos de crise, é utilizado o som de vozes, do que parecem ser manifestações de rua, no entanto é difícil precisar se pertencem 
de fato às poucas manifestações mostradas. Acreditamos que o som dessas vozes foi colocado em momento posterior ao das filmagens, para criar um efeito de dramaticidade. A melodia muda de característica na hora em que as forças armadas assumem o comando do país, reforçando a ideia de que os militares são os "salvadores da pátria" trazendo alívio ao país. Trata-se de uma música com características de uma marcha militar usada para representar a vitória em uma batalha. Em outros momentos o fundo musical é uma música cantada, semelhante a uma marcha de carnaval, que também lembra às características do denominado "hino" "Pra frente Brasil", composto na época da Copa do Mundo de Futebol de 1970, realizada no México, na qual o time brasileiro saiu vitorioso. Em outros momentos da trilha é utilizada a música "Aquarela do Brasil" de Ary Barroso. Nos últimos minutos do filme se faz uma retrospectiva dos "momentos dramáticos", sem narração, com closes que alternam as manchetes retratando a crise política e econômica, alternadas com imagens chocantes de violência, que supostamente o país vivia entre 1961 e 1964. Nesses minutos finais, a música também se caracteriza pelo tom dramático. De acordo com Krause (2016:258):

Nas últimas imagens, a tomada aérea de uma apresentação sinfônica na Quinta da Boa Vista (Rio de Janeiro), onde se realizava o Projeto Aquarius, evento muito popular que reunia milhares de pessoas ao ar livre para assistir concertos de música clássica. O narrador exalta a mistura de raças, um suposto comportamento social onde não haveria espaço para ódios e violências devido ao racismo e à intolerância religiosa, supostamente inexistentes no Brasil; a suposta esperança do povo apesar dos problemas, e uma suposta confiança inabalável no país, "graças a Deus!".

A seguir nos ocuparemos de indagar de que forma é caracterizado o inimigo no documentário brasileiro.

\subsection{0 inimigo}

Nos manuais elaborados pelo Departamento de Estudos da Escola Superior de Guerra aos quais nos referimos no Capítulo 1 desta dissertação, o termo "subversão" é amplamente descrito, inclusive utilizando verbetes de vários dicionários. De acordo com uma das definições dada no Manual 
"Conceituação de Guerra Insurrecional, Guerra Revolucionária, Subversão (guerra subversiva), Ação Psicológica, Guerra Psicológica e Guerra Fria":

A SUBVERSÃO pode ser considerada como uma transferência psicológica, de uma população, de um universo político dado para um universo político diferente"

GUERRA SUBVERSIVA - de âmbito local e de cunho tático, opõe-se, por meios insidiosos e clandestinos, à opinião pública dos países a neutralizar e a conquistar, procurando afastá-la, se possível voluntariamente, de seus chefes e de seu governo e leva-la a aceitar, desejar ou sujeitar-se a teses ou atos favoráveis à U.R.S.S" (EMFA, 1961:7)

Embora o termo "subversão" não seja utilizado, acreditamos que as denominações que estão no filme remetem a este conceito, principalmente aquelas que fazem referência direta aos extremistas e aos comunistas. Assim como no filme argentino são utilizadas formas plurais, tais como:

(05:42) Facções extremistas ameaçavam entrar em choque e não faziam segredo da posse de arsenais e de depósitos clandestinos de munição.

(06:12) Pelegos, agitadores, bajuladores e adesistas, aventureiros e por trás deles o comando vermelho dos comunistas.

(08:27) A união de pelegos e comunistas afiava suas armas.

(27:12) Receita que antes, quando falavam os falsos nacionalistas era absorvida na quase totalidade pelos armadores estrangeiros.

Esses grupos seriam os responsáveis pelo "caos absoluto, a desordem total, a violência sem freios nem medidas", esses momentos que o país viveu representam o "Brasil de Ontem", onde não havia nem "ordem, nem disciplina, nem progresso".

O inimigo é capaz de influenciar toda população, como podemos observar nesta sequência:

(06:21) E até gente séria, idealista, mas iludida, havia de tudo, havia de tudo naquele imenso caldeirão fervente em que se transformava 0 Brasil .

(12:53) E estes jovens, muitos deles foram testemunhas de que o inimigo estava atento e voltava à carga, às vezes servindo-se deles mesmos. Badernas e arruaças voltaram às ruas e com elas a insegurança e a intranquilidade. 
De acordo com o filme, o auge da crise chega com a quebra de hierarquia nos quartéis, referindo-se a uma suposta infiltração comunista nos militares de patente inferior, a quebra de hierarquia é apresentada como o momento crítico:

(07:40) Março, 1964, o drama brasileiro chegava ao auge, a indisciplina e a desordem acabaram por entrar nos quartéis, desmoronava o princípio da hierarquia e então via-se o país ameaçado de perder seu último ponto de apoio efetivo na manutenção da ordem pública.

Nesse sentido Chirio (2012) afirma:

Independentemente da geração e do grupo a que pertencem, os oficiais golpistas emitem um discurso bastante estereotipado sobre as razões que os levaram a derrubar o poder civil. Enfatizam em especial dois "perigos" principais, contra os quais o golpe teria sido o único e último baluarte: o de uma revolução comunista e o de uma "quebra de hierarquia" nas Forças Armadas por parte dos militares de patente inferior, fomentada por "agentes subversivos" infiltrados em seu meio dois perigos que teriam sido tolerados, até mesmo atiçados, pelo presidente João Goulart. (Chirio, 2012:17)

Consideramos importante lembrar o papel protagônico do inimigo representado em Ganamos la Paz e contrasta-lo com o do filme brasileiro. Embora tenha sua presença marcada, em Brasil de Ontem, Hoje e Amanhã a representação do inimigo ocupa menos espaço na enunciação. Acreditamos que isso se deve ao fato do filme abordar um período da história temporalmente mais distante, depois de transcorridos 11 anos do golpe militar. Os "agitadores" já foram neutralizados. Embora apresentado como perigoso e ainda presente em outros países do mundo, consideramos que o inimigo não é protagonista, como no filme argentino. O protagonista no documentário brasileiro é o país, não a população, mas o território brasileiro.

\subsubsection{Os salvadores da pátria}

Nesse contexto e diante desse inimigo a intervenção de 64 é apresentada como uma reação, como a legítima defesa dos ataques que o país sofria. É preciso destacar que, assim como no discurso dos militares 
argentinos, as forças armadas, também se apresentam como tendo a missão de "salvadores da pátria", como vemos nesta sequência:

(09:18) E o clamor de vozes conscientes encontrou eco em soluções inadiáveis, e as forças armadas, elas próprias mais do que ameaçadas foram chamadas, praticamente intimadas a cumprir a missão que o momento Ihes impunha, restabelecendo a ordem e livrando o país dos trapos vermelhos que ameaçavam sufocá-lo.

Essa visão da intervenção das forças armadas para salvar a nação circulou também na imprensa, como vimos no Capítulo 1, no qual citamos o editorial do Jornal O Globo de 2 de abril de 1964 chamado Ressurge a Democracia! : "Vive a Nação dias gloriosos. Porque souberam unir-se todos os patriotas, independentemente de vinculações políticas, simpatias ou opinião sobre problemas isolados, para salvar o que é essencial: a democracia, a lei e a ordem". Essa perspectiva também foi expressa em artigos de circulação restrita das forças armadas, como observamos em Chirio (2008:23) ao se referir a um artigo publicado por um coronel que era na época oficial de informações na Argélia:

Em várias passagens é indicado que, na reorganização sociopolítica e no esclarecimento das massas necessários à proteção das sociedades contra a revolução comunista, os militares têm o que dizer: "quando a salvação da Pátria está em jogo e quando, sozinhos, ao que parece conservam as verdades que podem salvá-la". Chirio (2008:23)

As forças armadas são representadas como os "salvadores da pátria", cuja missão é "salvar a pátria do caos social e da desordem", e apenas elas, as forças armadas são as detentoras da Verdade que pode salvar a nação, somente as forças armadas conservam e compreendem essa Verdade e podem "traduzi-la" para os interlocutores, lembrando assim as características do discurso constituinte. E são elas a única instituição capaz de salvar o país "dos trapos vermelhos que ameaçavam sufoca-lo".

Verificamos assim relações interdiscursivas entre os dois filmes, ao observar as representações do inimigo e seu poder de se infiltrar na sociedade, provocando assim uma série de sintomas da "doença do comunismo" e a instalação do "caos social" que antecede e justifica os golpes, bem como o papel de "salvadores da pátria" que as forças armadas desempenham. Essas relações parafrásticas ajudam a entender o motivo pelo qual consideramos que 
os textos sobre a "guerra revolucionária", que circulavam entre as forças armadas dos dois países, fazem parte das condições de produção dos documentários.

Observaremos a seguir qual o lugar que o enunciador se atribui e o que ele atribui ao co-enunciador, mais especificamente observaremos qual a é interlocução representada no documentário.

\subsection{A cena enunciativa e os locutores}

A cena enunciativa neste documentário se caracteriza pelo acesso à palavra de um enunciador-universal, que está fora da história, e que ocupa o lugar do qual se diz sobre o mundo (Guimarães, 20015:26). Observamos a instalação de um locutor que fala a partir de um lugar social de autoridade e de saber, o lugar de um educador, ele usa um tom pedagógico e amigável, mas também de autoridade. Esse educador se torna próximo do interlocutor ao se dirigir diretamente a ele.

Diante dessa proximidade, pensamos em um primeiro momento em chama-lo de "locutor-amigão", porque se aproxima do seu interlocutor, dirigindo-se a ele diretamente em tom quase familiar.

No entanto, pensamos que a figura do amigo é insuficiente porque apesar da proximidade estabelecida com o espectador, o locutor assume 0 papel de uma autoridade que é detentora de um saber histórico que compartilha com o espectador, mostrando a ele a "verdade" que funciona como uma memória. Pensamos que o papel que o locutor assume no filme se desdobra em vários papéis. Por um lado, ao usar um tom de objetividade e ao apresentar uma série dados comparados de diversas áreas da produção nacional, como diversos gráficos e tabelas, onde são realizadas projeções da produção nacional no período antes do golpe, como crescem as perspectivas de aumento da produção de matéria prima nacional, depois de 1964, o locutor ocupa um papel detentor de um saber que "ensina" o espectador, usando asserções e apresentando números que ilustram a Verdade. Pensamos assim no locutor-professor-gestor, devido ao seu caráter didático, que em alguns 
momentos parece pertencer ao ambiente empresarial, que apresenta aos investidores (grandes e pequenos), os riscos pelos quais a "empresa" passou (o Brasil de ontem) e os números e projeções de crescimento do Brasil de Hoje e Amanhã. Nessa perspectiva, o povo não está incluído como interlocutor. 0 locutor-professor-gestor se preocupa com a situação do povo, mas não conversa com ele e sim sobre ele, manifesta sua preocupação em proporcionar às camadas mais necessitadas aquilo de que elas precisam.

Em outros momentos, ao estabelecer uma proximidade maior com 0 interlocutor, o locutor assume um papel que denominamos locutor-padrinho. Pensamos nessa denominação por considerar o padrinho como aquela pessoa que oferece assistência, que não tem necessariamente vínculos sanguíneos com seus afilhados, mas que, no entanto, cuida deles, o padrinho oferece proteção e acompanha outra pessoa no seu desenvolvimento pessoal ou profissional, ele orienta, ele sabe e aconselha seu afilhado, porém apesar da proximidade e do suposto vínculo afetivo, o padrinho também é uma autoridade.

\subsection{A interlocução representada}

\subsubsection{Você se lembra?}

As várias interpelações que o locutor faz no filme, em forma de interrogação, dirigindo-se diretamente ao interlocutor usando o pessoal pronome pessoal você, dão uma impressão de certa proximidade. Esse recurso, é usado em muitas sequências do filme, como podemos observar:

(02:57) Naquela época você podia ler a manchete de que era pedida a falência do Banco do Brasil

(04:29) Foram tempos difíceis Você se lembra? Você, chefe de família. Você que não era criança há 11 anos atrás. Vocês que viveram aquele tempo. Vocês se lembram?

(05:41) Você se lembra? Facções extremistas ameaçavam entrar em choque e não faziam segredo da posse de arsenais e de depósitos clandestinos de munição 
(06:21) E até gente séria, idealista, mas iludida, havia de tudo, havia de tudo naquele imenso caldeirão fervente em que se transformava 0 Brasil. Você se lembra?

(7:09) Você gostaria de voltar àqueles tempos e experimentar as mesmas angústias e sentir as mesmas incertezas e inseguranças e voltar ao Brasil de ontem?

(08:45) Você se lembra? Era o Brasil de ontem, o Brasil de onze anos atrás.

(21:38) Um gigantesco e notável esforço de conquista, dos $17000 \mathrm{~km}$ 12000 já estão prontos, e tudo isso foi feito num prazo recorde feito por você, por você, brasileiro, nos últimos 5 anos, provando assim que ao final estamos sabendo ter pressa

(29:11) É o Brasil, um novo Brasil, o Brasil de hoje. Um Brasil que você só pode ter ideia do que ele representa, embora tanto falte fazer, se você se recordar do passado que ficou lá atrás.

(31:01) Você imaginou o que nos teria acontecido se essa crise fosse há 11 anos atrás?

(32:15) Há 11 anos passados havia também manchetes, mas, você se lembra? Elas falavam não de um Brasil que realiza,, mas de um Brasil enfermo, doente, falavam do gigante de joelhos.

(43:39) É assim, brasileiros, que neste depoimento verdade queremos que você veja que se nosso país ainda não é o paraíso que desejávamos - Deus nos livre, de vir a ser o inferno que lá de fora nos mostram em todos os setores do mundo

As interpelações recorrentes nos pareceram muito significativas. Nesse sentido, o texto de Roberto Damatta (1997) que analisa a circulação e os sentidos da expressão "Sabe com quem está falando?" nos deu uma perspectiva sobre o uso das formas interrogativas presentes no documentário. Para Damatta, a maioria das expressões que caracteriza a hierarquização de posições sociais assume a forma interrogativa, o que no Brasil surge como um modo não cordial. O autor afirma:

Em nossa sociedade, a indagação está ligada ao inquérito, forma de processamento jurídico acionado quando há suspeita de crime ou pecado, de modo que a pergunta deve ser evitada. Sem a interrogação, a vida social parece correr no seu fluxo normal, de modo que é possível postular uma provável ligação entre o temor das formas interrogativas e as sociedades preocupadas com a hierarquia, onde normalmente tudo deve estar em seu lugar. (Damatta, 1997:196) 
Ao utilizar as formas interrogativas o discurso assume parte das características de um inquérito cuja função é apurar a verdade sobre algum fato ou sobre uma suspeita. Nesse sentido, lembramos da heterogeneidade do discurso que exploramos no capítulo 2, que neste caso se dá através da entonação interrogativa e que dá ao discurso um outro estatuto (Authier Revouz [1982] 2011:8), semelhante ao de um inquérito.

Acreditamos que ao usar as interpelações interrogativas o locutor explicita seu lugar de autoridade do saber, ele mostra e "convida" seu interlocutor através da pergunta a lembrar do período prévio ao golpe, da forma como ele o apresenta.

O locutor põe em evidência uma relação verticalizada (de cima para baixo) usando a interrogação como expressão separadora, emite desde um lugar de saber algo como: "há um saber, há um lugar de saber e como você não sabe, ou não se lembra é exatamente assim que você deve se lembrar". É dessa forma que acreditamos que o locutor-padrinho assume seu lugar de autoridade, por um lado dando a impressão de proximidade ao interpelar o interlocutor diretamente, e por outro, utilizando a interrogação de maneira insistente, lembrando o inquérito.

Nesse sentido acreditamos que o locutor estabelece assim uma relação onde surge algo que Damatta (1997:192) chama de uma hierarquia baseada na intimidade social, que se caracteriza por uma tonalidade pessoal. Essa intimidade social é possível porque a desigualdade está tão profundamente enraizada na sociedade brasileira que esse tipo de tratamento mais próximo não abala, pelo contrário, reforça essa hierarquia. Como lemos em O’Donell (1984):

En Brasil, en cambio, las clases populares siempre han estado "en su lugar". Cierto, la historia de Brasil, desde la esclavitud inclusive en adelante, está puntuada por rebeliones que muestran hasta qué punto ese orden es un orden impuesto; pero esas rebeliones no han logrado cristalizarse en organizaciones o identidades colectivas que ocupen, con relativa pero no insignificante autonomía, un lugar propio bajo el sol de las clases dominantes. (O'DONNELL, 1984:29)

Para o autor a sociedade brasileira é uma sociedade mais autoritária do que a argentina, na qual a violência que garante a ordem está "normalizada", há uma hierarquia imposta que está incorporada na sociedade. 
O discurso do outro é utilizado para reforçar aquilo que o locutor narra. A presença de outros discursos é mostrada e marcada através das imagens de manchetes de jornais que contribuem para a representação do "Brasil de ontem", são manchetes de jornais como O Globo, Correio da Manhã, O Dia, que ilustram e corroboram aquilo que a voz em off narra. As manchetes mostram "notícias de greve, desabastecimento, falências, incitação à violência e medidas radicais por parte do governo Jango, bem como tumultos promovidos por comunistas".

Ao analisar o papel do locutor e verificarmos como ele oscila e assume diferentes lugares, observamos como a desigualdade social está presente na relação que ele estabelece com seu interlocutor e, portanto como é construída a figura deste. $\mathrm{O}$ interlocutor está explicitamente delimitado, o documentário está dirigido "aos jovens, os que esqueceram ou os que ainda não tinham nascido", portanto, o filme não estaria dirigido a toda a sociedade, mas apenas àqueles mencionados. O locutor compartilha parte do seu status com 0 interlocutor, assim como o professor compartilha o saber com seus alunos, que, de certa forma, acompanham e assimilam o conteúdo exposto em aula.

\subsubsection{Nós quem?}

Em Brasil de Ontem, Hoje e Amanhã observamos também a presença recorrente das marcas e desinências verbais que representam a primeira pessoa do plural e das formas "nós" "nos" e "nosso". Lembrando Indursky (1992:65) "por seu intermédio, o locutor pode associar-se a referentes variados, sem especifica-los linguisticamente, daí decorrendo a ambiguidade de seu dizer". Observaremos que a constituição do "nós" pode associar o "eu" a diversos referentes. Nestes fragmentos observamos que tanto os verbos conjugados na primeira pessoa do plural, quanto os possessivos "nossa" "nosso" podem fazer referência a um conjunto de autoridades, "nós, do governo, as autoridades" ou "nós, os que tomamos as decisões". Acreditamos que isso se evidencia nas seguintes sequências, nas quais o uso do "nós" e dos verbos conjugados na primeira pessoa do plural não inclui a comunidade 
de brasileiros, ela apenas é convidada a assistir aquilo que esse "nós" rememora sobre o "Brasil de Ontem", e o que ele projeta para o "Brasil de amanhã".

(01:15) Este é o Brasil cuja história começamos agora rememorar. Foi este país gigante, este Brasil de dimensões continentais o cenário dos fatos que vamos iniciar neste momento e que começamos a recordar na imagem de jovens que ainda eram crianças quando tudo aconteceu, ou de crianças que nem sequer haviam nascido quando tudo se passou. Dos que não puderam viver as experiências daquela época.

(01:44) E assim, a eles, aos jovens, aos que não viviam ainda dedicamos principalmente este programa.

(02:28) E voltemos, portanto, um pouco ao passado, sem ódio nem rancores, apenas para comparar.

(03:56) O Brasil é um país enfermo, dizia-se lá fora, será uma nova Indochina, o gigante está de joelhos, essa é a opinião corrente, fazendo ainda mais triste a nossa imagem pelo mundo afora. Pois o que se dizia no exterior apenas retratava nossa real situação, sem saber como seria o dia de amanhã.

(05:05) A produção se desarticulava, faltavam gêneros de primeira necessidade, pedíamos de joelhos aos credores que esperassem por nós.

(14:24) De afirmar ali a nossa soberania e aproveitar a nossas potencialidades econômicas e transformá-las também em potencialidades sociais

(20:25) Em Angra dos Reis, estado do Rio de Janeiro estamos construindo nossa primeira usina nuclear, mais duas serão lá instaladas e outras a seguir, irão se incorporar ao parque energético do país

(23:40) E hoje, quando comparamos presente e passado e reconhecemos que não estamos nem na metade do caminho, que dizer de há 11 anos atrás?

(27:29) 1964, exportações, um bilhão e 400 milhões de dólares, no ano passado, 7 bilhões e 500 milhões, vamos alcançar 20 bilhões em 79, esses números mostram quanto evoluímos no comércio exportador. É trabalho de brasileiros comprado pelo estrangeiro. E se compararmos hoje nossas exportações de manufaturados com as exportações totais de 64, teremos uma surpresa.

(28:12) Hoje competimos em preço e qualidade, por isso mesmo temos sido alvo de medidas discriminatórias contra o ingresso de nossos manufaturados em outros países, menos na Europa, muito mais nos EUA. Mas hoje temos altivez, dignidade, brasilidade coragem e competência para enfrentar os que pretendem intimidar o nosso desenvolvimento, temos agilidade para isso, abrindo o leque dos clientes, não importando a ideologia dos compradores, usando o poder 
de barganha que o próprio mercado brasileiro, tão cobiçado lá fora, agora nos oferece.

(29:29) Há 11 anos atrás, o nosso Produto Interno Bruto era quase ridículo, 20 bilhões de dólares, saltamos para 80 bilhões em 75, chegaremos aos 125 bilhões em 79, quando estiver cumprida a etapa do Segundo Plano Nacional de Desenvolvimento

(31:01) Você imaginou o que nos teria acontecido se essa crise fosse há 11 anos atrás? Nem é bom pensar. Claro, o fato de estarmos conseguindo hoje suportá-la com os preços do petróleo em níveis recordes, com a inflação que importamos lá fora dos produtos adquiridos mostra a capacidade de resistência, mostra que percorremos um longo caminho nos últimos 11 anos.

(32:07) Lá fora, no estrangeiro, temos sido motivo de admiração e confiança, manchetes destacam nosso avanço econômico.

(38:55) Com tudo que mostramos a vocês até agora, não dissemos nunca que o Brasil é um paraíso, temos muito que corrigir e assumimos essa verdade, com a consciência de quem sabe como são graves os problemas.

(39:56) Há 11 anos atrás cerca de $40 \%$ de nossa população acima dos 15 anos de idade era de analfabetos.

(43:21) É assim, brasileiros, que neste depoimento verdade queremos que você veja que se nosso país ainda não é o paraíso que desejávamos, Deus nos livre, de vir a ser o inferno que lá de fora nos mostram em todos os setores do mundo.

Nessas sequências que seguem, o "nós" apresenta maior abrangência, associado a outros referentes não especificados linguisticamente, que acreditamos está constituído pelas autoridades e alguns segmentos da sociedade brasileira: aqueles que não se lembram e que são constantemente intimados a lembrar da forma proposta. Esses segmentos da sociedade são, nas seguintes sequências, "convidados" a assumir determinadas formas de comportamento, reforçando assim o caráter disciplinador do locutor.

(42:14) A violência que impera lá fora em tudo aquilo que se pratica contra a dignidade da pessoa humana, das minorias treinadas, preparadas, determinadas a liquidar as maiorias iludindo-as com uma falsa ideologia, acreditemos em nós e ponto, e pensemos: ai de nós se essa violência aqui entrasse, ai de nós se o ódio se transformasse de fato na motivação de vida, para não dizer de morte, dos brasileiros de ódio, de retaliação, tudo isso não pode, não deve, não entrará no Brasil. Já é alguma coisa. Para que possamos com a nossa ordem, com a nossa paz, com a nossa dignidade evitar que daqui para fora, alguém de lá possa olhar para nós como nós olhamos para lá. 
(47:23) E se tudo aquilo que aqui mostramos num depoimento verdade valeu por alguma coisa, nestas palavras finais a nossa certeza de que todos nós, discordando dos limites da discordância digna e respeitosa, possamos pelo debate livre e consciente encontrar nossas próprias soluções dentro de casa. Porque certamente se assim agirmos, e se, como brasileiros que somos trocarmos ideias e só ideias, será possível alcançar a meta final de levar todo esse desenvolvimento dos últimos 10 anos à população inteira e acreditar mais do que nunca que os brasileiros que fizeram o que se fez neste decênio poderão muito e muito mais fazer se juntos e unidos tiverem forças, confiança e esperança de que o objetivo desejado da felicidade cada vez maior do povo brasileiro se torne muito breve uma grande realidade.

A seguir veremos como se constrói no filme brasileiro a figura daquele que não sabe, que não precisa ser ensinado e não precisa lembrar porque ele é colocado como um objeto do cenário: o povo.

\subsubsection{O povo e o(s) brasileiro(s)}

Verificamos que o povo não está incluído no papel de interlocutor, ou seja, a grande massa da população composta por jovens que pertencem ao "povo" está excluída. A figura do povo aparece ocupando um lugar que não é o do interlocutor, o locutor não se dirige a ele, o povo é mencionado na terceira pessoa, se fala dele, mas não se fala com ele nem para ele. O locutor não se inclui nesse item lexical, ele se refere ao povo, mas não faz parte dele. Também não é o interlocutor, ele não se dirige a ele. Podemos pensar assim que o povo aparece como representante das classes trabalhadoras que devem ser conduzidas para executar um projeto de país e de desenvolvimento, mas que não participa de sua elaboração.

Na seguinte formulação o povo aparece como massa de manobra que está nas ruas para pedir, mas não sabe exatamente o que está pedindo, podendo estar de um lado ou de outro, o povo desconhece suas próprias necessidades.

(05:20) E em última análise quem sofria era o povo, que era levado às ruas para pedir, talvez nem ele mesmo soubesse, o que. 
(13:23) Não se permitiria que aqueles anos de recuperação e sacrifício, e de grande sacrifício do próprio povo, fossem desperdiçados.

Nas seguintes sequências, o lugar de saber do locutor é reafirmado, ele sabe o que o povo precisa, sabe como realizar a felicidade do povo, sabe sobre o povo algo que ele não sabe sobre si. O locutor ocupa o lugar daquele que sabe tudo e constrói a figura do povo como aquele que nada sabe, estando sob a tutela do locutor, que se preocupa com as suas necessidades e lhe dispensa seus cuidados:

(23:14) Não que o de agora seja perfeito, falta muito, mas muito mesmo para que nos aproximemos do que o povo precisa, mas o importante é que se trabalha para isso".

(48:20).confiança e esperança de que o objetivo desejado da felicidade cada vez maior do povo brasileiro se torne muito breve uma grande realidade".

Nestas sequências, onde surgem "os brasileiros" o locutor não se inclui nesse grupo, reforçando assim a ideia de que ele está fora da história, ou ainda, acima dela, mas ao mesmo tempo, compreendendo as necessidades desses brasileiros e se preocupando com a sua situação:

(15:52) Entre eles a mais justa distribuição da renda entre os brasileiros, o fortalecimento da agricultura e da pecuária, bases indispensáveis à manutenção do dinamismo econômico e na criação da tecnologia nacional, um desafio a ser vencido.

(26:48) Recursos absorvidos por nossa indústria naval, gerando milhares e milhares de novos empregos para os brasileiros.

(27:48) É trabalho de brasileiros comprado pelo estrangeiro.

(37:09) Para essa legião de brasileiros, infelizmente maioria, reconheçamos, desenvolve-se agora todo um trabalho, no menor prazo de tempo possível, num compromisso de justiça, compromisso de melhor distribuição de renda, de abertura de oportunidades de emprego, de educação, saúde para os que nascem, para os que vivem, para os que não morrem ao nascer.

(39:39) O que se fez nestes 11 anos responde pelo que se pode fazer daqui por diante, por brasileiros como estes, que vivem nesse tipo de habitação que a todos nos deve envergonhar, cujo direito a uma vida melhora preocupa de fato a todos nós, porque somos todos responsáveis. Por isso, quase metade dos investimentos do segundo plano nacional de desenvolvimento visa a elevação do homem brasileiro. 
(43:21) É assim, brasileiros, que neste depoimento verdade queremos que você veja que se nosso país ainda não é o paraíso que desejávamos

Nas seguintes formulações o povo aparece precedido do possessivo "nosso", assim também como surge na sequência "gente nossa", construindo assim o sentido de que as massas "pertencem" ao locutor, que decide sobre seu destino:

(31:29) Mas é também advertência, no sentido de que precisamos até mesmo percorrer um caminho bem mais longo para que nosso povo não seja tão pobre como ainda é, e para que nos tornemos cada vez menos vulneráveis as crises do mundo de hoje.

(40:51) Mas precisamos acelerar ainda mais o passo, para que um número cada vez menor de brasileiros como esses sofra as agruras da miséria, dos desníveis regionais, das endemias, da subnutrição, pense nisso, como todos estamos pensando, para que a gente nossa não viva mais assim.

Na última sequência do filme, surge o nós mais abrangente, no qual o locutor se inclui. O locutor se iguala, e marca seu pertencimento ao mesmo grupo: "os brasileiros".

(47:23) E se tudo aquilo que aqui mostramos num depoimento verdade valeu por alguma coisa, nestas palavras finais a nossa certeza de que todos nós, discordando dos limites da discordância digna e respeitosa, possamos pelo debate livre e consciente encontrar nossas próprias soluções dentro de casa

Porque certamente se assim agirmos, e se, como brasileiros que somos trocarmos ideias e só ideias, será possível alcançar a meta final de levar todo esse desenvolvimento dos últimos 10 anos à população inteira e acreditar mais do que nunca que os brasileiros que fizeram o que se fez neste decênio poderão muito e muito mais fazer se juntos e unidos tiverem forças, confiança e esperança de que o objetivo desejado da felicidade cada vez maior do povo brasileiro se torne muito breve uma grande realidade.

Consideramos assim que a figura do povo aparece como parte do cenário e não como protagonista nem como interlocutor. O povo é visto como um instrumento para a realização do projeto das elites. Retomamos a citação de Oliveira (2008:58), para quem "o povo é visto como mero instrumento de construção do país, subalternos às ideias e projetos das elites" . 
Nesse sentido, é importante destacar os diferentes graus de desigualdade social historicamente acumulados no Brasil e na Argentina. Como observa Fanjul, (2016:85)

Os dois países dos quais tratamos, principais economias da América do Sul, apresentam históricos de desigualdade socioeconômica e também de uma violência política que, em alguns períodos e lugares, atingiu extrema crueldade. A pobreza e a exclusão de acesso a bens básicos para setores inteiros da população, bem como panoramas urbanos onde a miséria circula do lado da opulência o luxo fazem parte da sua cotidianeidade.

A pesar da desigualdade socioeconómica estar presente nos dois países, é importante destacar que ela era ainda mais acentuada no Brasil nos anos 70 do que na Argentina, tanto nos índices relativos ao nível de vida e ao analfabetismo quanto ao desemprego, à pobreza e à miséria, apontados pelos autores Fausto e Devoto (2004) no seu volume de história comparada.

Finalizamos assim este capítulo de análise, a seguir apresentamos algumas considerações finais sobre nosso trabalho. 


\section{CONSIDERAÇÕES FINAIS}

Neste momento de conclusão de nossa pesquisa, faremos uma síntese dos aspectos que consideramos mais importantes no trabalho analítico que realizamos. Sem pretender encerrar as reflexões em torno do corpus que selecionamos, mas sim, resumir em algumas linhas o percurso que fizemos até aqui.

Este trabalho está vinculado à Análise do Discurso francesa, teoria que nos permitiu incursionar em estudos produzidos em outras disciplinas tais como: a História do Brasil, a História da Argentina, a Geografia, o Cinema e na Linguística.

Quando começamos nossa pesquisa, em julho de 2013, o tema das ditaduras militares no Brasil e na Argentina, estava cronologicamente muito próximo, se considerarmos o tempo na História. No entanto, hoje, em dezembro de 2016, as ditaduras parecem estar mais próximas do que quando iniciamos nossa pesquisa. Os acontecimentos políticos no Brasil, que sofreu e sofre um forte retrocesso em termos democráticos e as medidas politico econômicas arbitrárias adotadas pelo governo argentino, nos fazem perceber as ditaduras como muito mais presentes temporalmente e emocionalmente.

Ao nos deparar com a dificuldade de obter algumas informações sobre os documentários-propaganda brasileiro e argentino, percebemos o quanto 0 "legado" dos regimes militares ainda é um incômodo, um assunto mal resolvido, uma página que, na opinião de muitos, seria melhor virar definitivamente. Guardadas as diferenças entre os processos vividos em cada país com a volta da democracia, no que diz respeito às políticas de memória, verdade e justiça, verificamos como, por diversos motivos, parte dos documentos que envolvem instituições e diferentes atores da época dos regimes foram destruídos e muitas pistas apagadas. É o caso das informações de produção e veiculação de Ganamos la Paz, e da adulteração que há na ficha técnica de Brasil de Ontem, Hoje e Amanhã. No caso do filme brasileiro, acreditamos que esse apagamento está estreitamente vinculado à mudança de posicionamento das Organizações Globo, com relação ao apoio dado na época ao regime militar, bem como ao papel que o programa Amaral Netto, o Repórter desempenhou naqueles tempos. No caso do filme argentino, sabemos que os militares se 
encarregaram de destruir muitos dos arquivos e documentos que registravam seus procedimentos. Alguns desses documentos foram resgatados recentemente, porém, muitas informações parecem ter se perdido para sempre. No entanto, essas lacunas de informação foram importantes, não apenas porque nos levaram a elaborar hipóteses sobre a origem e autoria dos documentários, mas fundamentalmente porque se tornaram um elemento importante de comparação entre eles. E foram precisamente essas lacunas as que nos levaram a indagar sobre as condições de produção nas quais esses discursos surgiram.

Dessa forma, indagamos a existência de manuais produzidos nos dois países no marco da doutrina francesa de Guerra Revolucionária. Incorporamos a existência desses manuais como parte das condições de produção, posto que, através deles, observamos as relações interdiscursivas entre esses textos e os documentários-propaganda objeto de nosso estudo.

O conceito de gêneros discursivos, e a descrição do gênero documentário e de suas modalidades de representação, mais especificamente da modalidade expositiva, nos levaram a observar o funcionamento discursivo nos dois filmes e reforçaram a forte comparabilidade existente entre ambos. Estabelecemos assim, relações entre o modo de representação do documentário e as características do discurso constituinte, assim como entre o lugar que o enunciador ocupa na cena enunciativa e o lugar social do locutor.

Com o conceito de heterogeneidade discursiva observamos como a presença de outros discursos e de outras vozes, ajuda a caracterizar o inimigo subversivo, e de forma antagônica, o lugar social que o locutor ocupa.

Analisando a materialidade linguística verificamos o forte caráter pedagógico, autoritário e disciplinador presente nos dois documentários bem como as relações interdiscursivas entre ambos.

Para finalizar, esperamos que a reflexão que desenvolvemos neste trabalho possa contribuir para os estudos comparados entre discursividades do Brasil e da Argentina e para a reflexão e a preservação da memória de nossos países. 


\section{Referências bibliográficas e de internet}

AUTHIER-REVOUZ, J. ([1982] 2011) Heterogeneidad mostrada y heterogeneidad constitutiva: Elementos para un abordaje del otro en el discurso. In: Detenerse ante las palabras. Estudios sobre la enunciación. Montevidéu: Fundación de Cultura Universitaria. (3-53)

BAJTíN, M, M. (1988) El problema de los géneros discursivos. In: Estética de la Creación Verbal. $8^{\underline{a}}$ ed. Siglo Veintiuno Editores.

CALVEIRO, Pilar. (2013) Poder e Desaparecimento. São Paulo: Boitempo.

CHIRIO, Maud. (2012) A política nos quartéis. Revoltas e protestos de oficiais na ditadura militar brasileira. Rio de Janeiro: Zahar.

COURTINE, Jean Jaques. (2009) Análise do discurso político. O discurso comunista endereçado aos cristãos. São Carlos: Edufscar.

DAMATTA, Roberto. (1997) Carnavais, Malandros e Heróis. Para uma sociologia do dilema brasileiro. Rio de Janeiro. $6^{\underline{a}}$ ed. Rocco.

ENDO, Paulo. (2012) A Vergonha e a Interpelação do Estrangeiro. Psicologia, violência e Direitos Humanos. $3^{\underline{a}}$ ed. São Paulo: Conselho Regional de Psicologia.

FANJUL, Adrián Pablo. ( 2015) Unidades do discurso, indagação comparativa e proximidade linguística: perspectivas e limites da categoria de "gênero". In: Letras de Hoje, Porto Alegre, v. 50, n. 4, p. 508-517.

(2016) A pessoa no discurso. Um estudo comparado entre o Brasil e a Argentina. São Paulo, Parábola. No prelo.

FAUSTO, Boris e DEVOTO, Fernando J. (2004) Brasil e Argentina: um ensaio de história comparada. São Paulo: Editora 34.

FEIERSTEIN, Daniel. (2000) Registros del Horror (Manual RC-5-2). http://www.catedras.fsoc.uba.ar/feierstein/Registros del \%20horror.pdf. Consulta em 11/2016.

GUIMARÃES, Eduardo. (2005) Semântica do Acontecimento. Campinas: Editora Pontes.

. (2013) Ler um texto: uma perspectiva enunciativa. In Revista da ABRALIN, v.12, n.2, p. 189-205, Universidade Estadual de Campinas.

INDURSKY, Freda. (1992) A fala dos quartéis e outras vozes. Uma análise do discurso presidencial da Terceira República brasileira (1964-1984). Tese apresentada no IEL/UNICAMP. 
KRAUSE, Katia. (2016) O Brasil de Amaral Netto, o Repórter - 1968-1985.

Tese apresentada no Programa de Pós-Graduação em História Social. PPGH da Universidade Federal Fluminense, Niterói, RJ.

LVOVICH, Daniel e BISQUET, Jaquelina.(2008) La cambiante memoria de la dictadura: discursos públicos, movimientos sociales y legitimidad democrática. Universidad Nacional de General Sarmiento. Buenos Aires: Biblioteca Nacional.

MAINGUENEAU, Dominique. (2008) Cenas da Enunciação. $2^{\underline{a}}$ ed. São Paulo: Parábola Editorial.

MARTINS FILHO, João Roberto. (2008) A influência doutrinária francesa sobre os militares brasileiros nos anos de 1960. In Revista Brasileira de Ciências Sociais vol.23 no.67, s/n. São Paulo. Consulta em 10/2016.

http://www.scielo.br/scielo.php?pid=S0102-

$69092008000200004 \&$ script=sci_abstract\&tlng=pt.

NAPOLITANO, Marcos. (2014) 1964, História do Regime Militar Brasileiro. São Paulo: Contexto.

NICHOLS, Bill. (1997) La representación de la realidad. Cuestiones y conceptos sobre el documental. Buenos Aires, Barcelona, México: Paidós.

O’DONNELL, Guillermo (1984) ¿Y a mí qué me importa? Notas sobre sociabilidad y política en Argentina y Brasil. Kellogg Institute. The Hellen Kellogg Institute for International Studies. Working paper.

. (1988) Argentina: a macropolítica e o cotidiano. In: Lua Nova:

Revista de Cultura e Política. oㅡ. 14, s/n São Paulo.

OLIVEIRA, I.T.M. (2008) Território e Identidade Nacional no Brasil. In Revista Urutágua № 15. Maringá: Universidade Estadual de Maringá (UEM). http://www.urutagua.uem.br/015/15oliveira.pdf. Consulta em 08/2016.

PALERMO, Vicente y NOVARO, Marcelo. (2011) La dictadura Militar 1976/1983 del Golpe de Estado a la Restauración democrática. Buenos Aires:

Paidós.

PECHEUX, M. ([1983], 2008). O Discurso. Estrutura ou acontecimento. Campinas: Editora Pontes.

PÊCHEUX, Michel \& FUCHS, Catherine ([1975] , 1990). A propósito da análise automática do discurso: atualização e perspectivas. In: GADET, Françoise, \& HAK,Tony (org.). Por uma análise automática do discurso. Campinas: Editora da UNICAMP.

RICARDO, Laécio. (2014) O documentário e a instilação da crença. In:

Significação Revista de Cultura Audiovisual, v. 41, n. 42.

- http://www.revistas.usp.br/significacao/article/view/83023/93453

Consulta em 07/ 2016. 
RISLER, Julia. (2011) La acción psicológica durante la última dictadura cívico militar (1976-1983): un acercamiento desde el análisis de la propaganda gráfica oficial". Instituto de Investigaciones Guido Germani, Facultad de Ciencias Sociales de la Universidad de Buenos Aires.

http://webiigg.sociales.uba.ar/iigg/jovenes investigadores/6jornadasjovenes/EJE\%202 \%20PDF/eje2 risler.pdf. Consulta em 07/2016.

SARLO, Beatriz. (2007) Tempo Passado Cultura da Memória e Guinada Subjetiva. São Paulo, Belo Horizonte: Companhia das Letras/ UFMG.

SUMMO, Marcelo y PONTORIERO, Esteban. (2012) Pensar la "guerra revolucionaria": doctrina antisubversiva francesa y legislación de defensa en la Argentina. (1958-1962). In Cuadernos de Marte. Revista Latinoamericana de Sociología de la Guerra III Año 2. Facultad de Ciencias Sociales. Universidad de Buenos Aires

http://biblioteca.clacso.edu.ar/Argentina/iigg-uba/20120817041505/cuadernosnro3.pdf. Consulta em 07/2016.

\section{Internet}

\section{Corpus}

Zappiens.br. Brasil de Ontem, Hoje e Amanha.

http://www.zappiens.br/portal/VisualizarVideo.do? Instanceldentifier=0\& Entityldentifie $\mathrm{r}=$ cgiVuE6vJFgLgErat193rQ5JfVTF47BciOEI3iFksCEEJU.\&idRepositorio=0\&modelo=0. Consulta entre 07/ 2013 e 12/2016

Canal Encuentro. Historia de un país.

Ganamos la Paz.

http://encuentro.gob.ar/programas/serie/8001/831.

Consulta entre 07/ 2013 e 12/2016

\section{Outras Referências de Internet}

Apuntes para la memoria.

http://www.pagina12.com.ar/diario/suplementos/espectaculos/9-24630-2012-03-

17.html. Consulta em 07/2016.

Biografia Amaral Neto.

http://www.fgv.br/cpdoc/acervo/dicionarios/verbete-biografico/fidelis-dos-santosamaral-neto. Consulta em 09/ 2016

Conceituação de Guerra Insurrecional, Guerra revolucionária, Subversão (Guerra Subversiva), Ação Psicológica, Guerra Psicológica e Guerra Fria. Estado Maior das Forças Armadas (EFMA). http://www.arganalagoa.ufscar.br/.

Consulta em 11/ 2016.

Dias Gloriosos da Globo e da Ditadura.

http://averdade.org.br/2016/04/os-dias-gloriosos-da-globo-e-da-ditadura/. Consulta em 07/ 2016. 
Diccionario Clarín.

http://www.clarin.com/diccionario.

Consulta em 08/2016.

Diccionario RAE.

http://dle.rae.es/.

Consulta em 10/ 2016.

Discurso de Videla de diciembre de 1975.

http://www.altillo.com/examenes/uba/cbc/semiologia/semio2007p1h.asp.

Consulta em 11/ 2016.

El archivo sudafricano

http://www.pagina12.com.ar/diario/elpais/1-256867-2014-10-05.html

Consulta em 07/2016

EBC - Empresa Brasil de Comunicação.

http://memoria.ebc.com.br/empresa.

Consulta em 09/ 2016.

Guerra sucia: la importancia de las palabras.

http://www.nuestrasvoces.com.ar/a-vos-te-creo/guerra-sucia-la-importancia-laspalabras/. Consulta em 09/2016.

La dictadura militar en Argentina 24/03/1976 a 10/12/1983.

http://www2.me.gov.ar/efeme/24demarzo/dictadura.html\#cabez.

Consulta em 12/2016. 


\section{ANEXOS}

\section{Transcrição dos filmes}

\section{BRASIL DE ONTEM HOJE E AMANHÃ}

Brasil, um país continente, $47 \%$, quase a metade de toda a América do Sul. Um gigantesco país cujos pontos extremos, norte e sul e leste oeste, distam mais de $4000 \mathrm{~km}$ nos dois sentidos. Um país difícil que em seu imenso território poderia colocar lado a lado toda a Europa menos a União Soviética, a América Central, o Japão, a Tailândia, Israel e ainda sobraria espaço.

Este é o Brasil cuja história começamos agora rememorar. Foi este país gigante, este Brasil de dimensões continentais o cenário dos fatos que vamos iniciar neste momento e que começamos a recordar na imagem de jovens que ainda eram crianças quando tudo aconteceu, ou de crianças que nem sequer haviam nascido quando tudo se passou. Dos que não puderam viver as experiências daquela época. $E$ assim, a eles, aos jovens, aos que não viviam ainda dedicamos principalmente este programa. Bem como a todos que aos poucos foram esquecendo os dramáticos instantes de 11 anos atrás, quando o Brasil era outro. Era o Brasil de ontem, uma nação em um momento histórico de uma gravíssima opção. E voltemos, portanto, um pouco ao passado, sem ódio nem rancores, apenas para comparar.

Foi há muito pouco tempo, há apenas 11 anos, e o Brasil sofria uma de suas piores crises: greves sobre greves, ameaça de guerra civil, caos quase incontrolável, deterioração econômica e financeira, indisciplina invadindo os quartéis, inflação galopante, forçando para o alto praticamente cada semana os preços de tudo. Foram momentos terríveis.

Naquela época você podia ler a manchete de que era pedida a falência do Banco do Brasil. Eis uma daquelas manchetes. Hoje parece humor negro, diante desse gigante que é o Banco do Brasil já se afirmando no mundo inteiro. Mas aconteceu. Os jovens de hoje, é certo, não se lembram disso, eram crianças naquele tempo, tempo de incertezas, o mundo num dos melhores períodos de prosperidade e o Brasil uma triste presença entre as exceções. Apontado como devedor difícil, de chapéu na mão, mendigando a todos, pedindo o reparcelamento de compromissos financeiros vencidos, em situação 
de quase insolvência, e visto, por sua importância no continente, como um barril de pólvora, cuja explosão levaria também o caos às nações vizinhas.

O Brasil é um país enfermo, dizia-se lá fora, será uma nova Indochina, o gigante está de joelhos, essa é a opinião corrente, fazendo ainda mais triste a nossa imagem pelo mundo afora. Pois o que se dizia no exterior apenas retratava nossa real situação, sem saber como seria o dia de amanhã. Ao sabor de sucessivas crises, mergulhados em um cotidiano de boataria e de incertezas. Foram tempos difíceis. Você se lembra? Você, chefe de família. Você que não era criança há 11 anos atrás. Vocês que viveram aquele tempo. Vocês se lembram?

Ultimatos ao congresso, agitações de rua, insegurança, ameaças aos jornais, agravamento da crise econômica e financeira. Já então total descontrole inflacionário. E tamanha desorganização, tamanho caos que em tudo deixava sua marca. A produção se desarticulava, faltavam gêneros de primeira necessidade, pedíamos de joelhos aos credores que esperassem por nós. Havia greves ao menor pretexto, filas para tudo. E em última análise, quem sofria era o povo, que era levado às ruas para pedir, talvez nem ele mesmo soubesse, o que. Perplexo, sem ter para quem apelar, à espera de uma solução fosse qual fosse e por pior que fosse melhor seria do que solução nenhuma, pois aos poucos o país e ia resvalando para o impasse final.

(05:41) Você se lembra? Facções extremistas ameaçavam entrar em choque e não faziam segredo da posse de arsenais e de depósitos clandestinos de munição. Era o caos irremediável que chegava a passos largos, e sobre o caos brotavam já o suborno e a corrupção, estava se armando o cenário para o capítulo final do drama, um drama de consequências imprevisíveis e que ninguém na época poderia dizer ao certo como iria terminar. Pelegos, agitadores, bajuladores e adesistas, aventureiros e por trás deles o comando vermelho dos comunistas.

E até gente séria, idealista, mas iludida, havia de tudo, havia de tudo naquele imenso caldeirão fervente em que se transformava o Brasil. Você se lembra? Não se sabia ao certo quem estava mesmo à frente do país, quem dirigia os destinos da nação, por isso não podia haver comando nem disciplina nem ordem e nem progresso. E muitos donos se diziam os verdadeiros donos da situação. Foi há onze anos atrás, há apenas onze anos. E hoje, ao 
documentar aquele passado ainda recente uma pergunta chega a se impor: Como foi possível aguentar? Como o Brasil resistiu? Pense nisso. Você gostaria de voltar àqueles tempos e experimentar as mesmas angústias e sentir as mesmas incertezas e inseguranças e voltar ao Brasil de ontem? E ler as mesmas manchetes e ler os mesmos espetáculos? A resposta fica com a consciência de cada um, com as responsabilidades que todos têm diante de si mesmos e diante de todos os demais brasileiros.

Março, 1964, o drama brasileiro chegava ao auge, a indisciplina e a desordem acabaram por entrar nos quartéis, desmoronava o princípio da hierarquia e então via-se o pais ameaçado de perder seu último ponto de apoio efetivo na manutenção da ordem pública. Dali em diante nada mais que o caos absoluto, a desordem total, a violência sem freios nem medidas, e a todos se evidenciou que o Brasil caminhava para o pior, caminhava para a guerra civil de consequências imprevisíveis. Foi há apenas onze anos atrás. O peso do medo e da angústia já era insuportável, falava-se em matar, em fuzilar, em destruir. A união de pelegos e comunistas afiava suas armas e tudo indicava que nos próximos dias ou nas próximas horas brasileiros se lançariam contra brasileiros no norte, no nordeste, no sul, nas cidades, no campo em toda parte. Você se lembra? Era o Brasil de ontem, o Brasil de onze anos atrás.

Foi no último instante, quase no momento derradeiro, quando o país estava à beira da guerra civil quase em pleno caos alguma coisa aconteceu. Era impossível continuar suportando tantos desmandos, tanta incompetência, tamanha anarquia. E o clamor de vozes conscientes encontrou eco em soluções inadiáveis, e as forças armadas, elas próprias mais do que ameaçadas foram chamadas, praticamente intimadas a cumprir a missão que o momento Ihes impunha, restabelecendo a ordem e livrando o país dos trapos vermelhos que ameaçavam sufocá-lo.

Abril de 1964 tomava posse então o presidente Humberto de Alencar Castelo Branco. Á sua frente uma tarefa enorme, normalizar a vida do país, recuperar Ihe as finanças e transpor o hiato havido nos anos anteriores, um hiato de marasmo e paralisia, tudo isso sufocando o desenvolvimento brasileiro. Foram tempos difíceis. Castelo Branco assumira o posto diante de um quadro inflacionário inédito no Brasil. Até o final de 64, caso medidas enérgicas não tivessem sido tomadas, a inflação caminharia para mais de $100 \%$. Seu período 
foi tipicamente de reconstrução, restabeleceu a autoridade mesmo a custa de incompreensão de tantos companheiros dos idos de março. Tomou medidas no sentido da restauração do crédito externo do país, lançou as bases dos sistemas de planejamentos globais em âmbito nacional e iniciou a retomada do progresso em seu governo.

Criou-se o BNH, o Banco Nacional da Habitação, era a ótica do desenvolvimento também no campo social sendo instaurada então, defeituosa ainda, mas semente de um grande ideal popular. Nos últimos 10 anos o BNH financiou cerca de 1 milhão de residências. Antes de sua criação diversos governos haviam levado quase 30 anos para financiar pouco mais de cem mil unidades residenciais. E Castelo Branco pôde deixar a governo dizendo "Entrego ao meu sucessor um país organizado e em ordem.

O governo Costa e Silva impulsionou ainda mais o desenvolvimento, foi assim 0 iniciador da escala de progresso dos anos mais recentes. Naquele período o país avançou no sentido de consolidar sua posição internacional. Abriu e conquistou novos mercados e no aspecto interno, os índices de desenvolvimento econômico começaram a demonstrar a recuperação atingida. Simultaneamente o processo inflacionário mais e mais se esvaziava. Diante desse panorama tentou-se uma liberalização gradual do regime, mas ainda não era tempo para isso. E estes jovens, muitos deles foram testemunhas de que 0 inimigo estava atento e voltava à carga, às vezes servindo-se deles mesmos. Badernas e arruaças voltaram às ruas e com elas a insegurança e a intranquilidade. Felizmente 1968 foi travado em tempo, havia a firme determinação de não se cogitar sequer do risco de uma volta ao passado.

(13:23) Não se permitiria que aqueles anos de recuperação e sacrifício, e de grande sacrifício do próprio povo, fossem desperdiçados. Ficou um saldo negativo, a interrupção de um diálogo que poderia ter frutificado, um diálogo nem sempre atendido pelos que ainda não se haviam convencido de que o Brasil de 1968 não era mais o Brasil de ontem.

E em 69, Emílio Garrastazú Médici, presidente. Nova etapa de grandes realizações, e como nunca o Brasil experimentou o ritmo acelerado do desenvolvimento, partimos para grandes desafios, entre eles a conquista da Amazônia, até então praticamente intocada, embora muito falada na voz dos demagogos. 
Foi lançado o Plano de Integração Nacional e a Transamazônica tornou-se um marco, um marco da histórica decisão de conquistar a Amazônia definitivamente para o território brasileiro. De afirmar ali a nossa soberania e aproveitar a nossas potencialidades econômicas e transformá-las também em potencialidades sociais. Transamazônica, as duzentas milhas de mar territorial, o Pró-terra, o PIS e o PASEP na área social, criando instrumentos financeiros de complementação do patrimônio de trabalhadores e funcionários.

No Governo Médici lançou-se o primeiro Plano Nacional de Desenvolvimento, suas metas foram quase todas superadas e aquele primeiro plano encontra seqüência agora no Segundo Plano Nacional de Desenvolvimento. Isto demonstra a continuidade de objetivos de desenvolvimento entre os governos da revolução. Continuidade sim, mas continuísmo nunca. Continuidade de propósitos, mas jamais continuísmo de pessoas ou lideranças carismáticas. Cada presidente da revolução em períodos certos passando a outras mãos 0 bastão de comando.

E veio a posse de Ernesto Geisel, o quarto presidente brasileiro dos idos de sessenta e quatro. Ao lançar o Segundo Plano Nacional de Desenvolvimento, seu governo deixou clara a preocupação social dos objetivos visados. Entre eles a mais justa distribuição da renda entre os brasileiros, o fortalecimento da agricultura e da pecuária, bases indispensáveis à manutenção do dinamismo econômico e na criação da tecnologia nacional, um desafio a ser vencido. E o alargamento do mercado interno se alinha entre as outras prioridades básicas. Prioridades como a energia, desenvolvimento nuclear. Pois falta ainda muito, mas muito mesmo a fazer no Brasil e é preciso que o que falta seja realizado no menor prazo possível.

As explosões do minério de ferro, um sinal de partida de novos tempos, do Brasil de hoje e do Brasil de amanhã. Tempos que deverão se afirmar cada vez mais, no sentido de que cada vez mais o Brasil seja mais justo com todos os seus filhos, mais igual, mais distributivo.

Em 64 a produção de aço era de dois milhões e oitocentas mil toneladas, hoje 8 milhões de toneladas anuais. Em 79 chegaremos a 22 milhões de toneladas. São números de enorme crescimento, que comprovam quanto o Brasil mudou e quanto continua mudando e crescendo. Para provar isso não bastam palavras, é preciso comparar, exibir fatos e números. Sem comparação, nada 
se deduz. E eles aí estão. Nos últimos 11 anos nossa siderurgia mais que triplicou sua capacidade, um enorme avanço que será outra vez triplicado até o final do Segundo Plano Nacional de Desenvolvimento, traçando assim um novo retrato de um novo Brasil de hoje e um Brasil para amanhã.

Há apenas 11 anos nossa potência instalada era de 6 milhões e oitocentos mil kWs, em 74, 17 milhões e até 1980, no final desta década, chegaremos aos 28 milhões de kWs. Sem energia não há desenvolvimento, por isso o Brasil acelera a construção de grandes centrais hidrelétricas.

(19:30) E aí está, na imagem que se segue, Urubupungá, o maior empreendimento do gênero no país e um dos seis maiores em todo o mundo. $\mathrm{Na}$ fronteira de São Paulo com Mato Grosso, o complexo hidrelétrico de Urubupungá é formado por duas grandes usinas, uma delas Jupiá, a outra Ilha Solteira, ambas represam as águas do rio Paraná e sua potência instalada final irá a quase 5 milhões de kWs. Ainda no mesmo rio, o Brasil e o Paraguai iniciarão as obras da maior hidrelétrica de todo o mundo, a usina de Itaipú, um gigantismo de uma capacidade instalada entre 10 e 12 milhões de kWs. São números do Brasil de hoje e do Brasil de amanhã.

Um país que busca também no átomo fontes de energia para uma crescente demanda futura. Em Angra dos Reis, estado do Rio de Janeiro estamos construindo nossa primeira usina nuclear, mais duas serão lá instaladas e outras a seguir, irão se incorporar ao parque energético do país. Pois não demorará muito e o consumo de energia terá esgotado a capacidade de suprimento hidrelétrico, assim a médio e longo prazos a alternativa é o átomo. E até o ano 2000 grande parte da energia consumida no Brasil será de origem nuclear.

Amazônia, ela representa 59\%, ou seja mais da metade de nosso território, era preciso incorporá-la definitivamente ao Brasil e para isso estão sendo abertos $17000 \mathrm{~km}$ de estradas na região. É a malha rodoviária de integração da Amazônia. Um gigantesco e notável esforço de conquista, dos 17000 km 12000 já estão prontos, e tudo isso foi feito num prazo recorde feito por você, por você, brasileiro, nos últimos 5 anos, provando assim que ao final estamos sabendo ter pressa. Pressa que é sinônimo do reconhecimento do quanto falta realizar e do quanto ainda o Brasil precisa de trabalho, de esforço para queimar etapas na construção de seu futuro. A Transamazônica, estrada que desfechou 
grande esforço de conquista tem cerca de $6000 \mathrm{~km}$, essa distância equivale a um percurso semelhante ao que liga Lisboa a Moscou e somente isso dá uma boa medida do seu significado. Transamazônica, Perimetral Norte, Cuiabá Santarém, Manaus- Porto velho, Manaus- Boa Vista, estradas que são vanguardas de colonização e que abrem caminho a descobertas de fabulosas riquezas minerais, assim como a implantação de grandes projetos pecuários e madeireiros . É a Amazônia por fim se incorporando efetivamente ao Brasil, e a Amazônia do urânio, dos não ferróceos é a Amazônia do Brasil de hoje.

(23:00) 1964, 183 mil veículos produzidos, este ano mais de um milhão. São números que representam dois Brasis, o de ontem e o de hoje. Não que o de agora seja perfeito, falta muito, mas muito mesmo para que nos aproximemos do que o povo precisa, mas o importante é que se trabalha para isso. Cruzar os braços ou lamentar o que falta em nada melhora a situação. A mentalidade de outros tempos, o palavrório e a demagogia não voltarão, não podem esconder a verdade dos fatos. E hoje, quando comparamos presente e passado e reconhecemos que não estamos nem na metade do caminho, que dizer de há 11 anos atrás?

17 mil km de estradas pavimentadas em 64. Hoje 5 vezes mais, 80 mil km e até 709 estaremos ultrapassando os 79 mil quilômetros. Você se lembra? Hoje é possível percorrer quase todo o Brasil sobre o asfalto. E ontem? Do extremo sul ao nordeste, do nordeste a Brasília, pelo litoral e pelo centro do país. Mais alguns meses e a última capital brasileira ainda não atingida verá o antigo sonho realizado, e com a inauguração da Manaus Porto velho seu isolamento terá fim, estará chegando a Manaus a primeira estrada, uma estrada asfaltada, uma vida negra de esperança cortando a Amazônia e ligando Manaus ao Brasil. E recuperamos as ferrovias, agora a prioridade número um na política de transportes. Muito breve a nova ligação São Paulo - Belo Horizonte verá suas obras iniciadas. Surgirá assim a ferrovia do minério, eletrificada de ponta a ponta, colocando nosso país entre aqueles que possuem traçados ferroviários de primeira categoria.

Apenas um milhão e quatrocentas mil toneladas em navios mercantes em 64, hoje mais de 5 milhões de toneladas e até 1980, 10 milhões de toneladas em navios. Em 64 a maior parte da frota era formada por unidades obsoletas, compradas quase todas no exterior, na média com 20 anos de uso. Hoje, a 
média de idade dos navios está abaixo dos 7 anos e na maior parte foram construídos em nossos estaleiros. Agora mesmo acaba de ser lançado um gigantesco programa de construção naval, compreende encomendas de mais de 750 navios e embarcações de todos os tipos, desde rebocadores a supergigantescos graneleiros, de navios de cabotagem a embarcações fluviais. $O$ valor dos contratos de construção vai além de 20 bilhões de cruzeiros. Recursos absorvidos por nossa indústria naval, gerando milhares e milhares de novos empregos para os brasileiros. Responsável essa indústria por uma nova presença do Brasil nos mares do mundo inteiro, presença que se efetiva no transporte de produtos nossos rumo aos mais distantes mercados, gerando também importante receita de fretes. Receita que antes, quando falavam os falsos nacionalistas era absorvida na quase totalidade pelos armadores estrangeiros.

1964, exportações, um bilhão e 400 milhões de dólares, no ano passado, 7 bilhões e 500 milhões, vamos alcançar 20 bilhões em 79, esses números mostram quanto evoluímos no comércio exportador. É trabalho de brasileiros comprado pelo estrangeiro. E se compararmos hoje nossas exportações de manufaturados com as exportações totais de 64 , teremos uma surpresa. $O$ ano passado, a receita em dólares de nossas vendas de produtos industrializados, superou 2 bilhões e 300 milhões de dólares, só em manufaturados quase 0 dobro de tudo que conseguimos exportar em 64, um reflexo da nossa expansão industrial..os nove cinqüenta exportava-se mais que em 64, ao invés de evoluir, portanto, antigamente estávamos andando para trás.

28:12 Hoje competimos em preço e qualidade, por isso mesmo temos sido alvo de medidas discriminatórias contra 0 ingresso de nossos manufaturados em outros países, menos na Europa, muito mais nos EUA. Mas hoje temos altivez, dignidade, brasilidade coragem e competência para enfrentar os que pretendem intimidar o nosso desenvolvimento, temos agilidade para isso, abrindo o leque dos clientes, não importando a ideologia dos compradores, usando o poder de barganha que o próprio mercado brasileiro, tão cobiçado lá fora, agora nos oferece. É o Brasil, um novo Brasil, o Brasil de hoje. Um Brasil que você só pode ter idéia do que ele representa, embora tanto falte fazer, se você se recordar do passado que ficou lá atrás. Há 11 anos atrás, o nosso Produto Interno Bruto era quase ridículo, 20 bilhões de dólares, saltamos para 
80 bilhões em 75, chegaremos aos 125 bilhões em 79, quando estiver cumprida a etapa do Segundo Plano Nacional de Desenvolvimento. O Produto Interno Bruto é o retrato do que se produz no país, daí a sua importância como forma de avaliação. Avaliação que corresponde a um diagnóstico, diagnóstico nem sempre agradável. Mas daqui por diante, nas duas últimas partes deste documento, preparem-se para ver e ouvir também coisas não muito agradáveis. Infelizmente, verdadeiras ainda. Pois este documento sincero, honesto, produto de pesquisa, é o documento de um país que se renova e que por isso, não teme a verdade.

Em 64 crescíamos apenas no Produto Interno Bruto em 2,9\%, em 74 10\% de expansão no Produto Interno Bruto, é qualquer coisa de espetacular quando o Japão no ano passado chegou a um crescimento zero, quando os níveis de desemprego nos EUA vão a 8 milhões de pessoas e quando o mundo premido pela crise do petróleo se debate em profunda convulsão econômica.

Você imaginou o que nos teria acontecido se essa crise fosse há 11 anos atrás? Nem é bom pensar. Claro, o fato de estarmos conseguindo hoje suportála com os preços do petróleo em níveis recordes, com a inflação que importamos dos produtos lá fora adquiridos mostra a capacidade de resistência, mostra que percorremos um longo caminho nos últimos 11 anos. Mas é também advertência, no sentido de que precisamos até mesmo percorrer um caminho bem mais longo para que nosso povo não seja tão pobre como ainda é, e para que nos tornemos cada vez menos vulneráveis as crises do mundo de hoje. Crises que não respeitam fronteiras, que não se detêm ante ideologias e que não permitem a vã ilusão de que escaparemos sem danos a seus efeitos.

Lá fora, no estrangeiro, temos sido motivo de admiração e confiança, manchetes destacam nosso avanço econômico. Há 11 anos passados havia também manchetes, mas, você se lembra? Elas falavam não de um Brasil que realiza,, mas de um Brasil enfermo, doente, falavam do gigante de joelhos.

(32:32) Hoje boas e más notícias nos chegam instantaneamente de todo o mundo e o Brasil está inteiramente coberto por microondas, deixou no passado há apenas 11 anos sua condição de país ilhado em mutismo, cego, surdo, mudo que falava, mas precariamente, com o mundo, que mal podia se comunicar dentro de seu próprio território. 
O Segundo Plano Nacional de Desenvolvimento estabelece a meta de $8 \%$ anual de expansão para o setor agrícola e pecuário e os investimentos na atividade rural irão acima de 100 bilhões de cruzeiros, o objetivo maior é o de dar técnica ao trabalho do campo, virtualmente triplicando até 79 o uso de equipamentos, matrizes, adubos e defensivos.

O Segundo Plano Nacional de Desenvolvimento para o período 75-79 vai mobilizar investimentos num volume inédito. Atentem para o gigantismo destes números, 1 trilhão, 750 bilhões de cruzeiros, a maior parte destinada diretamente ao homem, a você, a todos nós. Em educação, saúde pública, assistência médica, saneamento, nutrição, trabalho e treinamento profissional, serão aplicados 267 bilhões de cruzeiros. E habitação, previdência, PIS e PASEP 384 bilhões e no desenvolvimento social urbano 110 bilhões, total, quase 800 bilhões de cruzeiros, bem próximo da metade das inversões programadas pelo Segundo Plano Nacional de Desenvolvimento.

Agora, a maior entre todas as prioridades está na elevação do status do homem brasileiro, para que ele tenha mais saúde, bem-estar, nível de vida e possa assim melhorar participando do enorme esforço de construção de um grande país.

Se dividíssemos o bolo da renda nacional, o Produto Interno Bruto, cada brasileiro teria em 64, teoricamente, é lógico, 240 dólares, essa divisão teórica nos daria hoje 750 e o objetivo é fazer com que vá além de 1000 dólares em 79, muito pouco ainda, mas alguma coisa, comparando com o passado.

O Segundo Plano Nacional de Desenvolvimento dá especial destaque à participação do homem brasileiro na riqueza nacional, enfatiza a necessidade de melhorar a qualquer preço a distribuição da renda e não aceita as teses de que primeiro é preciso criar riqueza para depois distribuí-la, ao contrário, defende a distribuição simultânea ao crescimento econômico e sem prejuízo deste e há à frente de tudo isso a determinação incisiva de tentar por todos os meios acabar com as distorções que vêm se acumulando na questão da renda. (36:30) Na década de 40 e 50 a vida média do brasileiro não passava de 43 anos, de 60 a 70 a expectativa de vida saltou a 59 anos, é alguma coisa, mas não significa que estejamos sequer próximos do mínimo satisfatório, pois se muitos melhoraram de vida há ainda legiões de subnutridos, de portadores do mal de Chagas, de esquistossomose, do paludismo, da tuberculose, são 
vítimas do subdesenvolvimento, do subemprego, da condição de gente que não chega a participar da vida econômica do país. Para essa legião de brasileiros, infelizmente maioria, reconheçamos, desenvolve-se agora todo um trabalho, no menor prazo de tempo possível, num compromisso de justiça, compromisso de melhor distribuição de renda, de abertura de oportunidades de emprego, de educação, saúde para os que nascem, para os que vivem, para os que não morrem ao nascer. São metas do segundo plano nacional de desenvolvimento, pretendendo diminuir essa massa terrível daqueles que ainda não encontraram um lugar ao sol

Onze milhões e 500 mil estudantes no primeiro grau e segundos graus de ensino e na universidade, são números de 64, 21 milhões agora, e em 79 a previsão é de 27 milhões e 500 mil. Até á também, o programa de desenvolvimento científico e tecnológico vai receber verbas inéditas, e assim estaremos criando um knowhow nosso em inúmeras áreas indispensáveis ao desenvolvimento. $\mathrm{O}$ investimento em educação e tecnologia tem um retorno veloz inestimável na aceleração do desenvolvimento, cria-se com isso um poderoso fator de realimentação do progresso, o que vale dizer e definir como sendo um círculo virtuoso, virtuoso mesmo. Mais educação, mais tecnologia, igual a mais progresso, maior atividade econômica, mais empregos e maior bem-estar.

(38:55) Com tudo que mostramos a vocês até agora, não dissemos nunca que - Brasil é um paraíso, temos muito que corrigir e assumimos essa verdade, com a consciência de quem sabe como são graves os problemas. O que se fez nestes 11 anos responde pelo que se pode fazer daqui por diante, por brasileiros como estes, que vivem nesse tipo de habitação que a todos nos deve envergonhar, cujo direito a uma vida melhor preocupa de fato a todos nós, porque somos todos responsáveis. Por isso, quase metade dos investimentos do segundo plano nacional de desenvolvimento visa a elevação do homem brasileiro.

Há 11 anos atrás cerca de 40\% de nossa população acima dos 15 anos de idade era de analfabetos. Hoje esse percentual caiu a metade, ficando em torno de $20 \%$ e até 1980 a meta é erradicar o analfabetismo. Outra meta do segundo plano nacional de desenvolvimento pretende levar treinamento 
especializado a cerca de 400 mil trabalhadores anualmente, e treinamento especializado equivale a melhor posição profissional.

No período 75-79 o Segundo PND estimou um aumento na oferta de trabalho a taxas de 3,5\% ao ano. Até lá, 6 milhões e 600 mil novos empregos serão criados em todos os setores. Mas precisamos acelerar ainda mais o passo, para que um número cada vez menor de brasileiros como esses sofra as agruras da miséria, dos desníveis regionais, das endemias, da subnutrição, pense nisso, como todos estamos pensando, para que a gente nossa não viva mais assim. Basta prosseguir, acreditar, para que esta obra de gerações se torne, o mais rápido possível realidade, pela renovação

Diante de tudo isso abra uma janela para o mundo, debruce-se nela, olhe lá fora, em torno de você, porque abrindo uma janela para o mundo é que você pode ver a comparação, sentir que todos os dramas que vivemos, sentir que tudo aquilo contra o que protestamos, sentir que de fato, se este país ainda tem tanto por fazer, é preciso que se faça alguma coisa para acreditar no que falta diante do que se fez.

A violência que impera lá fora em tudo aquilo que se pratica contra a dignidade da pessoa humana, das minorias treinadas, preparadas, determinadas a liquidar as maiorias iludindo-as com uma falsa ideologia, acreditemos em nós e ponto, e pensemos: ai de nós se essa violência aqui entrasse, ai de nós se o ódio se transformasse de fato na motivação de vida, para não dizer de morte, dos brasileiros. E em meio a tudo que se passa lá fora, na janela em que você deve se debruçar, pense duas vezes, pense bem, o exemplo que nos mandam e tudo aquilo que sentimos de amargura, de terror, de pânico, de morte, de ódio, de retaliação, tudo isso não pode, não deve, não entrará no Brasil. Já é alguma coisa. Para que possamos com a nossa ordem, com a nossa paz, com a nossa dignidade evitar que daqui para fora, alguém de lá possa olhar para nós como nós olhamos para lá

43:21 É assim, brasileiros, que neste depoimento verdade queremos que você veja que se nosso país ainda não é o paraíso que desejávamos, Deus nos livre, de vir a ser o inferno que lá de fora nos mostram em todos os setores do mundo.

Este é o Brasil de amanhã, este é um Brasil diferente daquele que vem lá de fora, este é um Brasil que precisa de nós, na massa humana que compõe a 
população de mistura de raças, onde ninguém mata ninguém por ser preto ou branco, onde ninguém mata ninguém por ser protestante, espírita ou católico, onde todos se juntam, onde todos vivem com problemas incríveis e terríveis ainda, mas juntam-se porque têm esperança e sabem que o ódio não leva a nada, que a violência gera violência e que graças a Deus, há porque confiar neste país.

E se tudo aquilo que aqui mostramos num depoimento verdade valeu por alguma coisa, nestas palavras finais a nossa certeza de que todos nós, discordando dos limites da discordância digna e respeitosa, possamos pelo debate livre e consciente encontrar nossas próprias soluções dentro de casa. Porque certamente se assim agirmos, e se, como brasileiros que somos trocarmos ideias e só ideias, será possível alcançar a meta final de levar todo esse desenvolvimento dos últimos 10 anos à população inteira e acreditar mais do que nunca que os brasileiros que fizeram o que se fez neste decênio poderão muito e muito mais fazer se juntos e unidos tiverem forças, confiança e esperança de que o objetivo desejado da felicidade cada vez maior do povo brasileiro se torne muito breve uma grande realidade.

Zappiens - Último acesso em dezembro de 2016

http://www.zappiens.br/portal/VisualizarVideo.do;jsessionid=26F63112022959C E6569DE678D9C3E08? Instanceldentifier=0\& Entityldentifier=cgiVuE6vJFgLg Erqt193rQ5JfVTF47BciOEI3iFksCEEJU.\&idRepositorio=0

\section{GANAMOS LA PAZ}

El historiador y crítico de cine Fernando Martín Peña presenta Ganamos la Paz, un documental que, a modo de propaganda oficial de la Junta Militar, celebra el accionar político, económico y social llevado adelante durante el Proceso de Reorganización Nacional.

Fernando Martín Peña:

"Ganamos La paz" es una especie de institucional pero en lugar de ser de una empresa es de la última dictadura. Es una suerte de reescritura de la historia argentina que entonces era reciente, entonces digo hasta el momento de producción de la película que debe ser aproximadamente en 1977, en algún momento se menciona que ya está convocada la Argentina como locación del 
mundial de fútbol del 78, así que podemos suponer que la producción es de ese año, aunque no hay una fecha en los títulos de la película. Institucional de la dictadura quiere decir que la dictadura ofrece su versión, la versión de la junta militar, de lo que había pasado en la historia política argentina, desde la caída de Perón en el 55, la caída no, el golpe de estado que derroca a Perón en el 55 hasta el momento de realización del film. Por supuesto, lo que van a ver en ella es el uso sistemático, recurrente de términos del lenguaje que la dictadura se ocupó de demonizar, como por ejemplo ideología, una palabra que ellos utilizaban constantemente con una connotación negativa. Y también van a ver una serie de acontecimientos que todos saben que habían sucedido de determinada manera, ellos lo reescriben de otra completamente distinta y perversa.

Tiene un valor curioso la película además de ser el testimonio de la retórica de esta gente, testimonio de primera mano, digamos, un testimonio directo, como se pensaba la dictadura del 76 a sí misma. Además de ese valor, está también el valor que tienen las imágenes de archivo que la película tiene, hay una cantidad de material que no está presente en muchos de los documentales que han reconstruido distintas facetas de esa época, de esos años. Es decir, en general en la Argentina siempre cuesta encontrar material de archivo....documentalista es difícil encontrar material de archivo porque no hay ninguna entidad nacional que lo haya conservado nunca. No ha habido nunca acá ninguna política de preservación, entonces encontrar material de archivo como el que se ve en "Ganamos la Paz" como el que se ve de Ezeiza, como el que se ve del Cordobazo, por ejemplo, como el que se ve de muchos momentos que la película recorre, realmente le otorgan a este documental un valor accesorio. Pero sin duda, lo más inquietante, lo más aterrador que tiene la película es esta mirada sobre la historia y la concepción de ellos en relación con el ser nacional, en relación con lo que ellos entendían que habían hecho. ¿verdad?

Es notable como de una manera psicológicamente muy perversa le atribuyen a los otros los crímenes propios. En algún momento se habla en la película que en la Argentina previa al 76 se desconocían los derechos humanos, por ejemplo, y bueno que a partir del 76 se infiere que no, que la Argentina celebra la vida y la alegría y que todo está bien. En este sentido me parece que es una 
película que hay que ver y que permite además reflexionar profundamente sobre sus actos.

\section{LOCUTOR NARRADOR:}

El sol está siempre allí y su luz ilumina todas las cosas y todos los actos. Hasta en las sombras más espesas llegan algunos de sus reflejos para aclararnos la realidad, como en todas las verdades que veremos, imágenes auténticas, hechos reales captados por lentes inexorables. La Argentina es un país privilegiado por la naturaleza, de paz y de trabajo, con todos los paisajes y todos los climas, con montañas y llanuras, y con grandes ríos. Un país donde el hombre argentino fundó sus obras, y donde llegaron extranjeros de buena voluntad para cultivar la tierra, levantar industrias, y contribuir al engrandecimiento de nuestra república. Estas tierras ubérrimas atrajeron siempre las miradas codiciosas de los que quisieron conquistarlas y aprovechar sus riquezas, explotar la feracidad de sus praderas, de sus pampas famosas y esclavizar a sus hombres. Pero sus hombres aman la libertad y por ella son capaces de grandes cosas. El hombre argentino gusta vivir la vida en medio de sus hermosos panoramas. En el trabajo, se asoma al mar y toma sus frutos. Ara los campos, cultiva cereales, recoge los granos y convierte este suelo en la canasta de pan del mundo. Tiene una producción diversificada, vino de excelente calidad, frutas famosas en todas partes del mundo y también esquila finos vellones de las ovejas que pueblan la Patagonia, y obtiene las mejores carnes para su consumo e industrializa para la exportación hacia los más diversos mercados. A la par que mantiene la hermosa tradición de los gauchos de las pampas. Un pueblo que oraba su suelo para obtener los minerales que procesan sus altos hornos, modernos y de gran capacidad de producción. Que emplea técnicas avanzadas en sus plantas industriales, en sus talleres, con una amplia gama de equipos y maquinaria compleja que es operada con idoneidad. Con una tecnología que le permite procesar sus materias primas y obtener el combustible para cubrir sus necesidades vitales e incursionar en la búsqueda de otros insumos propios de la vida actual.

Con una capacidad que se trasunta en el sofisticado equipamiento para la investigación científica y que le ha permitido obtener tres premios Nobel en las 
personas de los doctores, Carlos Saavedra Lamas, Bernardo Houssay y Luis Federico Leloir.

Un pueblo que también descuella en varias actividades deportivas y exhibe varios campeones en la dura puja del pugilismo, ganando admiración en todas partes. Lo mismo que en el automovilismo de primera línea, o como en el tenis con figuras que no tienen parangón entre quienes lo practican en las distintas latitudes. O como en fútbol en cuyas filas abundan figuras de excepción, ganando el derecho de realizar el torneo mundial. Como en polo, asimismo, donde tiene el mayor conjunto de jugadores que exhibe 10 de handicap. $O$ las prácticas hípicas de destacado nivel.

En la Argentina se vivía en paz, pero en el mundo se expande el cáncer de la violencia ideológica, contamina nuestra América y busca la Argentina como blanco del terrorismo internacional.

Imagen y voz del Che Guevara: ...han llegado las palabras del compañero ....Inaudible

Periodista: (inaudible)

Che:... que no es que el embajador representando a la Unión Soviética esté de acuerdo con el discurso de Cuba, con la posición de Cuba, sino que la posición de Cuba es la que está de acuerdo con la Unión Soviética, el primer país que construyó el socialismo en el mundo

LOCUTOR NARRADOR: Ese movimiento se infiltró en nuestra sociedad, sembró armas en América pacífica, engañó a jóvenes y a adultos. Enseñó a matar. Así se asesinó, se copó aviones civiles y con frases hechas y arteros procederes confundieron las mentes. Lo hicieron quienes en Chile procuraron llegar por atajos siniestros a la conquista del poder, los que enarbolaron sus rojos pendones, los que burlaron a la democracia y la usaron solapadamente para entregar los pueblos al marxismo internacional, los personeros de esa ideología hablan y generan la violencia y la muerte.

En todas partes hay puños en alto, golpes, sangre, heridos, muertos. La marea siniestra llegó a oriente y también se enseñoreó allá la violencia irracional. En todas partes la paz es perturbada, las autoridades legítimas son desafiadas por los que predican el odio, la destrucción, las soluciones prepotentes.

Los derechos humanos son desconocidos por quienes propenden al caos y lo más sagrado, la vida misma, es arrasada en aras de esas ideologías. Muertos, 
heridos, sangre. La prédica disolvente llega a la Argentina también, siglas extrañas ensucian los muros, perturban las aulas y hay rostros iracundos $y$ puños. Así fue como estallaron disturbios en la Argentina con graves daños y muchas víctimas inocentes. Así fue como la calma cedió paso a las expresiones del odio, al golpe artero y a la sangre.

No solamente en Buenos Aires se asentó la violencia, otras ciudades del país sufrieron esa invasión siniestra. Rosario, Córdoba, los terroristas ensayan allí sus métodos destructivos, siempre el fuego, la pedrada, la bomba, las barricadas del odio y las víctimas sangrantes.

Quedan restos, esqueletos de vehículos incendiados, señales inequívocas en fin del terrorismo. La pasión malsana busca desde las sombras víctimas precisas, como cuando un alto dirigente sindical metalúrgico cayó bajo las balas asesinas, le sucedió luego la bomba que destruye. También fue secuestrado un ex presidente de la nación. La sociedad argentina se conmovió al comprobar cómo se extendía el cáncer. Un cáncer implacable que provoca muerte.

En un oscuro pueblito provinciano fueron descubiertos los restos lacerados del ex mandatario asesinado. Más horror, la ciudadanía argentina repudia esa crueldad. Tiempo después en una revista de las bandas subversivas, los delincuentes relataron con todo sadismo cómo habían actuado los asesinos del ex presidente argentino, no obviaron detalle alguno sobre ese crimen. Y sigue la serie sangrienta, otro líder sindical de destacada actuación es abatido cobardemente, víctima también de la violencia. Hijos y amigos lo lloran. Esa violencia parecía no tener fin: bombas, atentados de todo tipo, incendios intencionales. Son destruidos comercios para provocar pánico, tratar de imponer el terror y crear desabastecimiento. En definitiva, se busca el caos social, clima ideal para la subversión. Ante esa situación, ejecutivos de importantes empresas y funcionarios diplomáticos, en seguro a sus vidas y sus familias, abandonan el país.

PERIODISTA( entrevistando a Mario Roberto Santucho): ¿Ustedes tienen secuestrado al ejecutivo Thompson de la Firestone Estados Unidos?

SANTUCHO (respondiéndole al periodista) : No sé, no sé...no podría decirle, no...

LOCUTOR NARRADOR: Santucho, uno de los capitanes del caos, habla. 
SANTUCHO se ríe sin decir nada

LOCUTOR NARRADOR: .... manifiesta su cinismo.

Y la violencia persiste. En Rosario, mediante una emboscada cobarde, asesinan a un general cuando iba a su comando. Las balas también abaten a una humilde mujer. El mismo día, un destacado industrial italiano, padre de 4 hijos, es asesinado después de haber sufrido prolongado cautiverio, en manos de delincuentes terroristas.

El accionar de esas bandas parecía no tener límites, aunque muchos de sus cabecillas estaban presos, procesados ante la justicia común.

Agosto de 1972, la audacia es tremenda, el penal de Rawson, Chubut, es tomado. Coordinadamente copan un avión en Trelew. Treinta delincuentes huyen: Santucho, Menna, Quieto, Vaca Narvaja, Osatinsky y otros van a Chile entonces en manos marxistas. Pero retornarán para proseguir sus crímenes.

En medio de esa tensión retorna a Buenos Aires el ex presidente Perón, lo reciben los partidarios de su causa y hay elecciones. Asume la presidencia, como resultado de ellas, Héctor Cámpora. Son testigos mandatarios marxistas de América. Por esa vía hay infiltración roja en el movimiento popular. El ministro del interior de ese gobierno es un factor decisivo. Sectores ciudadanos salieron a las calles y plazas para celebrar su triunfo electoral. Y detrás de ellos estuvieron los marxistas enmascarados para retomar las sendas de la violencia. Otra vez las llamas destruyendo y los puños en alto, los gritos de odio, las piedras agresivas. La provocación descarada.

Y mientras las fuerzas del orden procuran evitar daños mayores, la Plaza de Mayo, recinto de los acontecimientos históricos argentinos, es invadida ese 25 de mayo de 1973, por carteles marxistas y puños en alto.

Entretanto, los cómplices de la subversión encaramados en el gobierno, a la sombra de un equívoco concepto de la libertad, abren las puertas de las cárceles a los delincuentes. Retornan desde los penales del sur en aviones. ¿Acaso para sumarse a la paz? No. Vuelven en actitud violenta al robo y al asesinato. Dejan las rejas tras de sí y son recibidos como héroes, por sus secuaces.

Los ideólogos de la violencia no han renunciado al objetivo de alcanzar el poder por cualquier procedimiento y penetran en las universidades y otros 
institutos de enseñanza para copar las mentes juveniles, torcer sus destinos y tratar de adueñarse de las futuras clases dirigentes del país.

20 de junio de 1973. Perón retorna definitivamente al país. Columnas de manifestantes se vuelcan en las proximidades del Aeropuerto de Ezeiza para darle la bienvenida. Pero la infiltración ideológica ha provocado una honda división en el movimiento. Mientras la masa permanece confiada a la espera de sus dirigentes, las bandas extremistas en busca de la propia hegemonía se enfrentan en una verdadera batalla campal. Estalla la violencia. Hay tiros, gritos iracundos, hay víctimas y por sobre el ulular de las sirenas se oye el gemido de los heridos.

Muchos huyen tratando de ponerse a salvo de los disparos. Otros, anónimos personeros del caos, empuñan armas de guerra y emplean tácticas propias de las guerrillas urbanas evidenciando intenso adiestramiento. $Y$ hay una víctima principal: la mayoría que permanece azorada, ajena a esta explosión extremista.

Todo eso fue excesivo. Renuncia Cámpora a la presidencia y se van sus secuaces marxistas. Y asume otra vez Perón tras nuevas elecciones. Recuerda otras épocas, otras circunstancias. Pero su movimiento ya no es el mismo, está profundamente infiltrado por los elementos terroristas que lo han penetrado para aprovecharlo. Lo demuestran en sus actitudes y en sus manifestaciones. Puesto ante esa realidad, el presidente habla a la multitud y lo hace desde atrás de un cristal de seguridad que apenas permite apreciar su imagen. Las organizaciones terroristas se burlan del gobierno. Habían simulado apoyarlo, después, a su sombra siguieron asesinando. Como cuando mataron a dirigentes gremiales, inclusive máximos conductores de las entidades obreras. El estupor se generaliza entre el pueblo. Nadie se siente seguro.

Llega el día del trabajo y Perón reúne a sus seguidores en la Plaza de Mayo frente a la casa de gobierno, les habla y acusa a los infiltrados en su movimiento.

PERÓN: ...pese a esos estúpidos que gritan.

LOCUTOR NARRADOR: Su censura a la subversión es áspera y directa PERÓN: han visto caer a sus dirigentes asesinados, sin que haya todavía sonado el escarmiento (...) 
LOCUTOR NARRADOR: Los grupos subversivos que en otros tiempos él había alentado y que ahora disimulaban en sus filas, reaccionan ante tan clara alusión. Se van de la plaza y trazan un evidente enfrentamiento con el gobierno legal.

Acentúa la subversión marxista su accionar. Hay más masacres. El terrorismo indiscriminado cobra otras víctimas. Caen civiles, militares, sacerdotes. Quieren imponer el terror, paralizar el cuerpo social de la República.

En ese clima, el primero de julio de 1974, fallece el presidente Perón. Su viuda, vicepresidente de la nación, asume el Poder Ejecutivo según las normas de reemplazo previstas. El gobierno ve acentuar su desgaste en forma persistente e irreversible.

Los grupos subversivos pretenden crear una zona dominada en una de las provincias más queridas por los argentinos: Tucumán. Se ocultan en montes y montañas, pero el Ejército Argentino es llamado a actuar y en forma contundente aplasta esa pretensión.

Entonces los delincuentes vuelven a la acción urbana y se afincan en las universidades. Detonan bombas y causan más daños y víctimas. Impotentes ya para intentar el copamiento territorial, después de la derrota de Tucumán, quieren destruir y amedrentar. Desafían al gobierno que no acierta con las medidas adecuadas y asesinan al propio jefe de la Policía Federal. Continuamente caían víctimas del terrorismo. Entre otros atentados, colocan una bomba cerca de un edificio militar y causan la muerte de un camionero y heridas a pasajeros de un ómnibus.

La propia gente del gobierno comienza a rebelarse, las autoridades tambalean y se genera vacío de poder. Las Fuerzas Armadas adoptan severas medidas para evitar males mayores a la República.

Y el audaz ataque al arsenal de Monte Chingolo es rechazado con graves pérdidas para las organizaciones subversivas que quedan desmanteladas como fuerza. Es el principio del fin para ellas.

MILICO: [...] Capitán Petruzzi, Teniente Primero Spinazi, sargento ayudante Cisterna, soldado Rufolo, soldado Caballero, soldado XXX, quiera Dios Nuestro Señor en la inmensidad y la altura de Su Majestad darle el descanso a estas almas. Y que ilumine al Pueblo Argentino para que el martirio no sea en vano. Descansen en paz. 
LOCUTOR NARRADOR: El Gobierno pierde el control de la situación. Los políticos no encuentran soluciones al vacío de poder. Las publicaciones periódicas se hacen eco, se cierra un período oscuro para la historia del país. Las fuerzas armadas se ven en la obligación de asumir el poder y lo hacen el 24 de marzo de 1976 para preservar la integridad de la nación.

Muchos resortes de la delincuencia subversiva se aflojan. Sufre un duro revés cuando un militar cautivo, encerrado durante varios meses en un estrecho pozo, logró evadirse para volver a las filas del ejército. La ciudadanía recupera la confianza en las fuerzas del orden.

Las autoridades acentúan su acción, es una vasta contraofensiva de las fuerzas legales. Muchos delincuentes son apresados, se les toma armas, se descubren talleres clandestinos donde las fabricaban o reparaban. La documentación secuestrada a los extremistas pone en manifiesto el peligro en que estuvo la nación. $Y$ también se desbaratan maniobras financieras entroncadas con la subversión. La violencia recorre nuestro tiempo como una trágica manifestación del fanatismo irracional, de la agresión ideológica. A la vista de ese culto despiadado al terror y a la muerte, ¿qué pueden esperar los pueblos a los que ofrecen un sistema fundado sobre el miedo y el desprecio a la vida humana?

El horror ha quedado atrás. La sociedad argentina pasó una durísima prueba. Ha llegado el momento de ganar la paz y de preguntarnos primero: ¿en nombre de qué cayeron los héroes y mártires de esta lucha?

Pues cayeron en nombre de Dios que nos da la vida, en nombre de la patria que nos brinda todo para vivir en la paz del trabajo y del hogar.

$Y$ ha llegado el momento de preguntarnos también: ¿Quiénes serán los destinatarios de esta victoria? Serán los millones de argentinos que buscan una causa fundada en el amor, en la justicia y en la libertad. Una causa que, con la fuerza invencible de los ideales más nobles, triunfe sobre la violencia los extremismos y el odio. Se habrá ganado así la paz para los argentinos, se habrá contribuido a formular un mundo mejor. $Y$ al dar gracias al Señor por esos logros, exaltando imágenes de vida y de amor, podremos exclamar con énfasis: ¡Ganamos la paz!

Canal Encuentro - Acesso em dezembro de 2016 http://www.conectate.gob.ar/sitios/conectate/busqueda/buscar?rec id=100388 